\title{
IETS UIT DE NALATENSCHAP
}

V A N

\author{
Mr. D. KOORDERS.
}

Nog was de tijding van het overlijden van Dr. W. H. Engelmann niet in Nederland aangekomen, of de tweede beoefenaar van de Soendaneesche taal, mr. D. Koorders, was reeds door den dood aan de wetenschap ontrukt, voordat hij de taak, die hij op zich had genomen, ten einde had kunnen brengen. Zoo is misschien dan nu weêr voor langen tijd onze verwachting van weldra grondige wetenschappelijke werken betreffende het Soendaneesch te ontvangen, teleurgsteld. Van harte hopen wij dat een andere krachtige hand dit zal kunnen opvatten.

Mr. D. Koorders, in het begin van 1867 in Nederland teruggekeerd, had in het voorjaar van 1868 bij het overlijden van $\mathrm{mr}$. S. Keyzer op zich genomen de lessen in de staatsinstellingen van Ned. Indie aan de Inrichting voor Indisch Onderwijs te Delft te geven. Hierdoor werd onze vroegere kennismaking hernieuwd, en het deed mij innig leed den genialen man zoo spoedig reeds te zien vallen. Recht aangenaam was het me daarom door Mevr. de Wed. Koorders in de gelegenheid gesteld te worden nog eenige van zijne nagelaten papieren door te zien, en verlof te krijgen, daaruit eenige stukken, die mij geschikt voorkwamen, in het licht te geven. Vooraf geef ik een korte schets van Koorders verrichtingen gedurende zijn verblijf in Indië.

Onder de korrespondentie vond ik een aantal rapporten over de Soendaneesche volks- en leesboekjes, die mij zoo belangrijk voorkwamen, dat ik besloot aan het Bestuur van het Koninklijk Instituut voor de Taal-, Land en Volkenkunde van Ned. Indië de uitgave daarvan voor te stellen na bekomen verlof van de bevoegde macht. Dit verlof door Zijne Excellentie den Minister van Koloniën welwillend verleend zijnde, volgen die rapporten als eerste stuk hierna. Ook waren er vele aanteekeningen, dikwijls met potlood of op losse stukję geschreven, die hij op zijne 
verschillende uitstapjes door het gebied van de Soendaneesche taal alleen voor eigen gebruik of van zijn naaste familie maakte. Onder veel, dat niet voor 't publiek geschikt is, kwamen me de naauwkeurige beschrijvingen van den afgelegden weg, de dikwijls geestige opmerkingen omtrent land en volk zoo belangrijk voor, dat ik niet heb geaarzeld ook fragmenten daaruit hier bij te voegen. Jammer dat van het zoo interessant bezoek bij de Badoewi's een groot deel wordt gemist; ik heb getracht uit blijkbaar onder weg of bij het aanhooren gemaakte notities nog enkele bijzonderheden mede te deelen, doch dit kan natuurlijk het ontbrekende niet vergoeden.

$\mathrm{Na}$ te Utrecht tot doctor in de theologie, en later in de rechten te zijn gepromoveerd, bezocht mr. Daniel Koorders van September 1860 tot Julij 1861 de voormalige Delftsche Akademie, om den rang van Oost-Indisch Ambtenaar van de 1ste klasse te verkrijgen; hij deed het gevorderd examen met het beste succes, werd tot ambtenaar benoemd en vertrok den $26^{\text {sten }}$ November 1861 naar Batavia, waar hij den 13den Maart 1862 aankwam. Hem was medegegeven een aanbeveling voor de Indische regeering om zijn gebleken kunde dienstbaar te maken aan de beoefening van eenig vak van wetenschap in Nederl. Indië.

Bij besluit van 17 April 1862 werd mr. Koorders "belast met de voortzetting van het onderzoek naar de waarde der in graan- en ijzerpakhuizen te Batavia aanwezige boeken en papieren "; daarna, den 30sten April " toegevoegd aan Jhr. Mr. H. C. van der Wijck, ten einde dat raadslid ten dienste te staan bij het opmaken der verslagen omtrent hetgeen zoo door partikulieren, als van regeeringswege is verrigt tot herstel of leniging van de rampen ontstaan door watersnood in Midden-Java."

Omstreeks dien tijd was de kwestie van het oprichten van een kweekschool voor onderwijzers in de Soendalanden bij het Gouvernement aanhangig, en werd met Koorders onderhandeld om aan het hoofd van die kweekschool geplaatst te worden.

Inmiddels werd het onderzoek van de wormstekige en halfverteerde papieren in de graanpakhuizen voortgezet, totdat Koorders bij besluit van 5 Augustus 1862 daarvan werd ontheven en verlof kreeg zich te Bandoeng te vestigen in afwachting van nadere bestemming. Hij bleef evenwel wegens huiselijke omstandigheden die maand nog te Batavia, en werd bij besluit van 27 Augustus gelast zich naar Bandoeng te begeven om 
daar onder de leiding van den heer K. F. Holle zich de kennis der Soendaneesche taal eigen te maken en voor zooveel noodig dezen behulpzaam te zijn in het beramen van hetgeen tot het onderwijs in de Soendalanden dienstig zou zijn. De beoefening van het Soendaneesch had toen nog weinig door Europeaneu plaats. De bovengenoemde heer K. F. Holle en de heer J. Rigg waren de eenigen, die daarvan nog bewijzen hadden gegeven. De eerste stond Koorders overeenkomstig genoemd besluit bij in zijne studiën. Doch slechts voor korten tijd. Koorders was een wetenschappelijk, Holle een praktisch gevormd man; bovendien waren zij ook in alle andere opzichten antipoden; humne zienswijze over Indië en zijne bewoners verschilde hemelsbreed; er kwamen allerlei botsingen en geheele oneenigheid volgde, toen Koorders zich in zijn onverholen oprechtheid met de hem eigen kracht van taal in 't algemeen en bepaaldelijk bij het Gouvernement op ongunstige wijze uitliet over de volgens advies van den heer Holle uitgegeven Soendaneesche volks- en leesboekjes.

Tegen den heer Rigg trad Koorders ook weldra op door eenige artikelen in de Javabode te plaatsen, waarin het Woordenboek voor het Soendaneesch van dien heer werd beoordeeld, Februarij 1863. Achtereenvolgens werden bezwaren geuit tegen 't geen in de inleiding van dat werk over de uitspraak is gezegd; tegen de woordafleiding; tegen het niet onderscheiden van de taalsoorten, en hetgeen over "idiomatic expressions " wordt gezegd; terwijl verder, naar Koorders meening, veel verkeerds over de beteekenis van woorden en afgeleidde vormen kon worden opgemerkt. Hij velt hierom een ongunstig oordeel over dat werk, een oordeel, dat hij later bij verschillende gelegenheden heeft bevestigd.

De heer G. J. Grashuis, die zich in de Soendalanden bevond om werkzaam te zijn voor de Bijbelvertaling namens de Nederlandsche Zendingvereeniging, plaatste in hetzelfde blad eenige opmerkingen omtrent Koorders beoordeeling. Hij trachtte deze eenigzins te verzachten, en bestreed Koorders gevoelens op enkele punten. De Javabode van 14 Maart 1863 bevatte het antwoord, waarin ook de stellingen van den heer Grashuis werden weêrsproken.

$\mathrm{Na}$ de oneenigheid met den heer Holle schijnt er een oogenblik kwestie van te zijn geweest, dat Koorders in 's lands gewone dienst zou overgaan. $\mathrm{Hij}_{i j}$ is echter in zijn betrekking gebleven en heeft zich zelfstandig op het Soendaneesch, en vooral op de verschillende dialekten daarvan toegelegd. 
In het laatst van dit jaar werd door de Regermng zijn gevoelen gevraagd over de door haar nitgegeven Soendaneesche lees- en volksboekjes. In een reeks van allerbelangrijkste rapporten werd hieraan door hem voldaan, en zijne meening onbeschroomd uitgesproken; deze rapporten zijn hierachter gedeeltelijk opgenomen. Wij leeren hem daarin wederom kennen als scherpzinnig opmerker, logisch denker en keurig stylist, en moeten ons verbazen over de uitgebreidde kennis, die hij in betrekkelijk korten tijd van het Soendaneesch had verworven.

Den 31sten Mei 1864 werd het laatste rapport verzonden, en den volgenden dag aanvaardde Koorders de reis door Zuid-Bantam, voornamelijk met het doel om zich met de aldaar gesproken dialekten van het Soendaneesch bekend te maken. Van een journaal, op die reis gehouden, volgen hierachter als tweede stuk van zijn hand, de voor de uitgave geschikt geachte gedeelten. Men kan hem daar bijna van dag tot dag volgen; de weg en de bezochte plaatsen worden naauwkeurig beschreven, en de fijne waarnemer vertoont zich ook hier van alle kanten. Dit zoo weinig bezocht gedeelte van Java leeren wij hieruit vrij goed kennen en velerlei bijzonderheden treffen ons, die tot nu toe onbekend waren.

Eenigen tijd te voren had Koorders nog in de Javabode geplaatst twee artikelen ter bestrijding van de brochure van Bartholo: "het Indisch Schoolwezen en de Evangelisatie in Nederl. Indië ", waarin verlangd werden invoering van de Nederlandsche taal op alle inlandsche scholen, en oprichting van een kweekschool voor de vorming van inlandsche onderwijzers in Nederland.

Aan het einde van dit jaar kwam Koorders met andere Indische taalkundigen op tegen het bekende werkje "Taco Roorda's beoefening van het Javaansch bekeken door H. N. van der Tuuk." Later is hierover nog een afzonderlijk boekje van Koorders verschenen onder den titel : "Over den heer H. N. van der Tuuk en zijne jongste geschriften " waarin hij verscheiden gevoelens van dien geleerde - bestreed, ook met voorbeelden uit het Soendaneesch.

Zooals wij boven zagen, was Koorders bestemd om aan het hoofd te staan van de op te richten kweekschool voor onderderwijzers in de Soendalanden. Vooral de breuk met den heer Holle en waarschijnlijk andere omstandigheden hebben er aanleiding toe gegeven, dat deze bestemming niet is vervuld. Den 11 den Februarij 1865 werd èn besluit genomen, waarin gezegd werd, dat "men hem voor die betrekking minder gesehikt achtte, 
en men zijn talenten en bekwaamheden liever wilde gebruiken voor de studie van het Soendaneesch, om daarvan een woordenboek en grammatica te maken." Dit was zeker een zeer verstandig besluit. De loop, dien de zaken genomen hadden, was niet geschikt om hem sympathie voor het onderwijs in te boezemen; ook was hij te veel geleerde, die, niet met weinig tevreden, altijd naar 't volmaakte streefde; en wat zijn karakter betreft te openhartig om als hij onrecht of iets verkeerds zag, te zwijgen; de dagelijksche routine van zulk een school kwam al heel weinig daarmede overeen.

Met hetzelfde doel als de reis door Zuid-Bantam werden in dit en 't volgende jaar (1865_-1866) nog verschillende tochtjes ondernomen; het eerste door de afdeeling Soekapoera, later door Tjeribon tot Tagal en Brebes; in Mei van 1866 door Soemedang en in Junij door de zuidelijke en westelijke districten van Tjiandjoer. Enkele aanteekeningen, doch lang niet zoo geregeld en uitvoerig als de vroegere, zijn gevonden en laten wij ook hierachter gedeeltelijk volgen.

In die jaren schijnt Koorders ook reeds met zijn gezondheid te hebben gesukkeld; toch beijverde hij zich steeds zijn woordenkennis te vermeerderen door afluistering van gesprekken met verschillende personeu, het aanhooren en opteekenen van verschillende verhalen, waartoe hij de toekang-pantoen en tembangzangers bij zich liet komen; hierin dus een andere methode volgende dan op zijn Bantamsche reis.

Gedurig vinden we in zijn korrespondentie bewijzen van de moeijelijkheden, waarin ook de verhouding tot den heer Holle hem wikkelden. Niet kunnende zwijgen waar hij meende in zijn recht te zijn, hield hij ook steeds vol met de Soendaneesche leesboekjes te veroordeelen, en ook met het Goevernement kwam hij in minder goede betrekking. In Maart 1866 werd hij verzocht binnen den tijd van 3 maanden een schets van een grammatica voor de Soendaneesche taal in te zenden. Van deze kommissie verzocht hij evenwel verschoond te blijven, doch beloofde aan het einde van het jaar voorstellen te doen tot uitgave van een SoendaneeschHollandsch Woordenboek met de schets van een grammatica; voor het eerste was hịj steeds bezig bouwstoffen te verzamelen.

In October deed hij nog een reis door het Buitenzorgsche, bepaaldelijk met het oog op het Woordenboek van Rigg, en verder door het Bantamsche tot naauwkeuriger bestudeering van het daar gesproken dialect. 
Inmiddels verbeterde zijn gezondheid niet. Het klimaat scheen daarvoor ook niet gunstig te zijn. Weken lang was hem soms alle inspannend werk verboden. Toch werktē hij zooveel mogelijk aan zijn taak voort, daarin bijgestaan door zijn inlandschen schrijver, Masroen, een neef van den Pangoeloe van Bandoeng, en een zeer ontwikkeld man, die hem op zijne reisjes steeds vergezelde. Zijn ongesteldheid verergerde evenwel in het laatst van dat jaar zoozeer, dat hem door zijn geneesheer gelast werd onmiddelijk naar Europa te vertrekken. Hij vroeg en verkreeg verlof voor twee jaren, doch wenschte dien tijd toch dienstbaar te maken aan de bewerking van het Soendaneesche Woordenboek. De voorstellen, die hij daartoe deed, o. a. ook tot het medenemen van zijn inlandschen helper, op wien hij bijzonder veel vertrouwen stelde, werden echter door den Goeverneur-Generaal aan den Minister van Kolonien ter beslissing overgelaten. Terwijl Koorders, reeds op het punt zijnde van te vertrekken, zich nog te Bandoeng bevond, ontving hij de in Nederland uitgegeven vertaling van het Evangelie van Lukas door den heer G. J. Grashuis. Terstond schreef hij hier over een korte af keurende vermelding in de Javabode van 2 Januarij 1867, die onlangs nog in het Tijdschrft van Ned. Indie is opgenomen. De 28e Januarij was de laatste dag, dien hij op Java doorbracht, en met de fransche mail vertrok hij naar Europa. De reis werkte gunstig op zijn gestel, doch zich eenigen tijd in Duitschland ophoudende, gaf hij te Salzburg bloed op, zoodat hij eerst in Mei in Nederland aankwam, waar evenwel een langdurige zware ziekte hem aan den rand van 't graf bracht, en werkzaamheid onmogelijk makkte. Hij vestigde zich met zijn gezin te Bennebroek bij Haarlem, en nam daar het Soendaneesche Woordenboek weder onder handen, waarvan aau het eind van het jaar een groot aantal woorden waren afgewerkt. Hij drong everwel herhaaldelijk aan op de overkomst van zijn inlandschen schrijver. Inmiddels had hij ook zijn oordeel over het Evangelie van Lukas in het Soendaneesch, waarvan boven is gesproken, uitvoeriger gegeven en nader gemotiveerd in een brochure, getiteld: "Taalen Bijbelmishandeling. Aan het Bestuur van de Nederlandsche Zendingvereeniging ", uitgegeven bij Kemink en Zoon te Utrecht. Dit werkje was tevens een antwoord op het boekje van den heer Grashuis: "Waan en dunk " en werden met meer nadruk de gronden aangegeven, waarom Koorders het door bovengenoemd bestuur aangenomen rapport bestreed en de verspreiding van dit Evangelie ontried. Met scherpzinnigheid en juist gevoel van 
de taal worden veel uitdrukkingen in dit boek afgekeurd, de verdediging van Grashuis ontzenuwd, en Koorders oordeel gehandhaafd nevens dat van Dr. Engelmann (Vrg. Tijdschrift v. N. I. April 1869).

Eindelijk kwam er tijding, dat aan zijn verzoek gevolg zou worden gegeven, en dat Masroen zich reeds te Batavia bevond op weg naar Holland, toen Koorders tot lid van de Tweede Kamer voor Haarlem werd gekozen, en hij, zich met zijn bekenden ijver en geestdrift aan de nieuwe werkzaamheden wijdende, de taalstudie op zij zette, den djoeroe-toelis afschreef, zoodat deze dan ook niet in Holland is aangekomen.

Niettegenstaande hij het zich als kamerlid tamelijk druk maakte, bleef hij voortgaan met het geven van de kollegies over het publiek en administratief recht van Ned. Indie aan de Instelling te Delft, waar zij op hoogen prijs werden gesteld. Hoe kort mogt dit evenwel slechts duren! Heeft hij zich te veel met deze werkzaamheden overspannen? Was zijn reeds geschokte gezondheid daartegen niet bestand? Zeker is het, dat hij zich niet gunde rust te nemen, die hem zoo dringend werd aanbevolen, en eerst de lessen staakte, toen het spreken hem te moeijelijk viel; doch de zittingen van de Kamer bleef hij steeds bijwonen, tot dat hij in haar kerstrecès tijd had om ziek te zijn, zooals hij zich uitdrukte. Het was toen evenwel te ver gekomen; zijne ziekte had een te hoogen graad bereikt, zoodat geneeskundige hulp niet meer baatte, en na een martelend lijden overleed hij den 26sten Januarij 1869, 38 jaren oud.

Een veelzijdig ontwikkeld man was in hem wederom aan het vaderland, een verdienstelijk geleerde aan de wetenschap ontvallen!

Mochten de hier volgende stukken van Koorders hand zooveel leering en genoegen verschaffen aan anderen, als ze mij deden, dan zal het voorname doel van huune plaatsing, Koorders werkzaamheid in Indie te doen kennen, des te beter worden bereikt.

Ik heb getracht, zooveel mijn geringe kennis van het Soendaneesch en mijne weinige hulpmiddelen toelieten, opheldering te geven, waar die noodig schenen. De aanteekeningen onder den tekst geplaatst zijn van mij.

Delfft, October 1869 .

J. J. Meinsma. 


\section{RAPPORTEN OVER SOENDANEESCHE LEES- EN VOLKSBOEKJES. 1}

\section{Bandoeng, 14 December 1863.}

In aanvankelijke voldoening aan den last, op mij verstrekt bij UwEdGestr. missive van 7 November jl. $\mathrm{n}^{\mathrm{o}}$. 2517 , zal ik de eer hebben, bij deze der Regeering mijn gevoelen keubaar te maken over de arararagy วлณ (gelijk het op de keerzijde van den titel genoemd wordt) "Radja Darma ".

Binnen een paar maanden tijds van al de Soendaneesche werkjens, waarover de Regeering mijn oordeel gevraagd heeft, een behoorlijk af- en uitgewerkte kritiek te leveren, is ondoenlijk; ik zal daarom, van de mij verleende vrijheid gebruik makend, mijn verslag bij-gedeelten indienen.

Zoo de beoordeeling van de Radja Darma langer is uitgebleven dan ik gewenscht had, zoo met de voorbereiding daarvan nagenoech een maand is verloopen; het is, omdat ik het miju plicht achtte, bij deze gelegenheid in eenige algemeene beschouwingen te treden omtrent den vorm der boekjens (dat woord genomen in zijn ruimsten zin). Het is mijn vaste overtuiging, dat daaraan groote gebreken kleven; gebreken, zógroot, dat ze de offers, die de Regeering zich sints een paar jaren ter ontwikkeling van de Soendalanden getroost, voor de bevolking nutteloos en voor de taal schadelijk dreigen te maken.

Mijn eerste grieve tegen den vorm der door de Regeering uitgegeven Soendaneesche volksboeken is, dat het inet uitzondering der boekjens van den heer Holle, allen tembangs zijn.

$\mathrm{Ik}$ zeg met opzet: tembangs. Het is onnaauwkeurig, dat woord door gedicht te vertalen. Ze hebben met onze gedichten nieth e t-m in st e gemeen. Veeleer zou men ze dan noch met den naam van zangstukken kunnen bestempelen. Maar het is enkel bij

1 Al deze rapporten zijn gericht aan den 1 n Gouvernementssekretaris. 
gebrek aan een eigen Hollandsch woord, dat we plegen te zeggen: de tembangs worden gezongen, niet gelezen. Alleen het Engelsche chanting geeft, voor zoover mij bekend is, het begrip juist en volkomen weêr. Ik zou het daarom verkieslijk achten, den Soendaneeschen tembang zijn Soendaneeschen naam te laten behouden; woorden als melodrama en opera b. v. laten we evenzoo wijselijk onvertaald.

Tegen de verspreiding nu van zulke tembangs heb ik drie zeer gewigtige bedenkingen.

Vooreerst: ze bederven in den grond de zuiverheid der ta al. De reden ligt voor-de-hand. Elke poepoeh of zangwijs (een tembang is altijd afgedeeld in poepoeh's) bestaat uit pada's of koepletten, van welke elke regel in zijn eindlettergreep een onveranderlijk-vaststaanden klank moet hebben. Zoo (om de zaak door een voorbeeld op-te-helderen) heeft de zangwijs, die pangkoer heet, in elk koeplet (bestaande uit zeven regels) als eindklank van den eersten regel altijd een $a$, van den tweeden een $i$, van den derden een $o e$, van den vierden een $a$, van den vijfden een $o e$, van den zesden een $a$ en van den zevenden een $i{ }^{1}$. Wat doet nu de tembangmaker? Aan zijn eindklanken gebonden, gebruikt hij een hoog woord, waar eigenlijk een laag zou moeten staan (b. v. sirah, als hij een $a$ noodig heeft, inplaats van hoeloe [hoofd]); en wat erger is, in-plaats-van een Soendaneesch woord Maleisch, Javaansch, ja Arabiesch en Kawi (zoo b. v. pati, wapat, ja palastra in-plaats-van paèh [dood], soembar in-plaats-van nangtang $[?],=$ ten strijde uitdagen; mědal in-plaats-van bidjil, uitkomen; en honderd anderen). Dit is geen uitzondering; het is vaste, doorgaande, volstrekt-algemeene regel. Schrikwekkend-lange lijsten zou $\mathrm{ik}$, ten bewijze daarvan, der Regeering kunnen voorleggen. Trouwens, de tembangmaker houdt het voor een onschadelijk iets; en of hij daardoor onverstaanbaar wordt, deert hem niet; hij weet wel, dat het zijn zoogenaamde lezers om den klank, meer dan om den zin der woorden te doen is. En het is toch waarlijk allesbehalve een onschadelijk iets. Het is een moedwillige en stelselmatige vervreemding der landzaten van hun moedertaal, gelijk ons vaderland onder de Graven uit het Bourgondiesche huis er een beleefd heefl. Een moedwillige en stelselmatige vernieling,

1 Ik wil er met een enkel woord op wijzen, dat alles, wat hier van de Soendaneesche tembangs gezegd wordt, ook van de Javaansche geldt, waarvan zij hoogst waarschijnlijk zijn overgenomen.

M. 
van hetgeen het eigenaardigst kenmerk en de onmisbaarste levensvoorwaarde eener nationaliteit is. Een streven om de levende deelen van het taalorganisme te doen versterven en te vervangen door niet-geassimileerde, mechaniesch-aangevoegde bestanddeelen van uitheemschen oorsprong: om het Soendaneesch, die zelfstandige loot van den Polynezieschen taalstam, vol leven en vormkracht, die in zoo-hooge mate van vatbaarheid voor ontwikkeling getuigt, en als voertuig van ontwikkeling zulke uitnemende diensten kan doen, van zijn eenheid, zijn leven naar eigen wetten, volgens welke het verstorvene wordt uitgestooten, en het nieuwe, vreemde, organiesch opgenomen, te berooven; met andere woorden: om het te doen ophouden een taal te zijn, en tot het peil van het laag Maleisch, het Negerengelsch en de Lingua Franca te doen wechzinken.

In de tweede plaats: de tembangs doen zelfs den uitwendigen vorm der woorden en de regelen van zinbouw op alle mogelijke wijzen geweld aan. De tembangmaker is niet-enkel aan bepaalde eindklanken, hij is in elken regel van elke zangwijs ook aan een bepaald getal lettergrepen gebonden. Dit zou hem natuurlijk wel eens in verlegenheid kumnen brengen. Maar hij heeft een zeer eenvoudig redmiddel bij-de-hand. Gelijk hij zich, waar hij een $a$ als eindklank noodig heeft, niet ontziet, Bopati tot Bopatja, ja Patih tot Patja te vervormen, zoo doet hij, al-naar-gelang hij anders een lettergreep te-veel of te-weinig zou krijgen, de woorden een inkrimpings- of uitrekkings-proces ondergaan. Van djero b. v. maakt hij, desgevorderd, het voor den Polyneziër méer-nog dan voor den Hollander onuitspreekbare djro; van het kollektief voorvoegsel para een vorm pra, alsof het van het voorvoegsel pra niet in vorm gelijk in zin ten-eenenmale verschilde; van dalapan, met volkomen hetzelfde recht als wị kanalen zouden samentrekken tot knalen, dlapan, van montong het geheel onverstaanbare tong; en omgekeerd saperti tot sapereti, mangarti tot mangareti, perloe tot pereloe, prakara tot palakara, kersa tot keresa. Daarmêe noch-niet te vreden, vervangt hij b. v. het persoonlijk voornaamwoord van den tweeden persoon manèh door dat van den derden manèhna; gebruikt in-plaats-van rèja-rèjana $=$ op zijn meest, rèjana $=$ de hoeveelheid er van; laat prepozities wech, waar het Soendaneesche taaleigen ze gebiedend vordert; verzwijgt het subjekt van een zin of zinsnede, ook waar die verzwijging de bitterste verwarring veroorzaakt; en berooft den objektieven- 
of passiefvorm der zeg: en werkwoorden van het voorvoegsel dat hem tot passiefvorm stempelt. Dit is te betreuren, niemand, geloof ik, zal het betwisten. En het is in de gegeven omstandigheden allergevaarlijkst tevens. Wat we in Nederland broddelaars als Schenkman en konzorten zonder nadeel dan alleen voor hun eigen reputatie zien doen, omdat taal en volk er beide ontwikkeld zijn, mag in de allereerste gedrukte stukken, die de Regeering onder de oogen van de bevolking der Soendalanden brengt, mijns-inziens niet geduld worden, omdat hier de schrijftaal zoo-te-zeggen noch geschapen moet worden, en ze gevaar zou loopen een afdruk, niet van de levende, maar van de tembangtaal te worden. De toch-al-zoo-algemeene dwaling, dat wat gebruikt wordt, ook goed is, zou worden bestendigd. De taalbedervers zouden de kroon op het hoofd krijgen, en hun onzinnige schrijfwijze, als de bij-uitstek fatsoenlijke, als de door het Gouvernement goedgekeurde, meer-en-meer worden nagevolgd.

In de derde en laatste plaats: de tembang is uit zijn a ard ongeschikt om an ontwikkeling en beschaving een krachtigen stoot te geven. Reeds uit het boven-gezegde Jaat zich dat affeiden. Het onophoudelijk gebruik van allerlei vreemde woorden, van allerlei onverstaanbare zinwendingen, van allerlei bepaalde ongerijmdheden, waartoe de tembangmaker ter wille van voetmaat en eindklank wel gedwongen is, heeft natuurlijk voor den lezer dit dubbel nadeel : dat veel van den inhoud hem onbegrijpelijk blijft, en hij uit den vorm niet leeren kan, hoe men zich met juistheid moet uitdrukken. Reeds om dit-laatste alleen zou ik dan ook hun invoering als leerboeken allerbedenkelijkst achten; in die besmette atmosfeer mogten de kinderen ook eens beginnen te spreken van opium, die aan wal gaat (handjat), of van een kris die vrïgelaten (oetjoel) is. Doch, ook geheel-onafhankelijk van dit een-enander, acht ik ontwikkeling van den Soendanees door verspreiding van tembangs een ondoenlijk iets; en wel om de eenvoudige reden, dat de tembangs $\mathrm{z}$ an gstukken zijn. Het eigenaardige van den zang is, dat hij bij-voorkeur tot 's menschen gemoed en verbeelding spreekt, weinig-of-niet tot zijn verstand en rede. Hij vordert geen werksaamheid, laat-staan: zelfwerksaamheid van den geest; enkel ontfankelijkheid van, gemoed. Hij speelt zijn hoofdrol in den kinderleeftijd der volken, wanneer het sluimerend denkvermogen noch-niet is ontwaakt. Wie een volk beschaven wil, zal wel moeten beginnen met het aan onderzoek 
en nadenken te wennen; heeft hij kans van slagen, wanneer hij het hulpmiddel van den zang te-baat neemt, die aan zijn hoofddoel, het weêrgeven van toonen en klanken al het andere ondergeschikt makt, en medebrengt, ja vordert, dat men aan die toonen en klanken werktuigelijk hangen blijft? Is er kans, dat men al zingende leeren zal, gelijk het kind, wanneer de periode voorbij is waarin het door wiegezangen in-slaap-gesust werd, al-spelende leert? Mij schijnt het een contradictio in terminis. En hoe men beweeren kan, dat verspreiding van tembangs onder de bevolking althans dit-éene voordeel zou hebben, dat ze het middel, en wel " het eenigste middel " zouden zijn "om den inlander spoedig aan het lezen te krijgen" is me een raadsel. Mij schïnt die redeneering even-logiesch, alsof ouders zeiden: we moeten ons kind maar druk laten rijden, om het spoedig aan het loopen te krijgen. Een weinig kennis van de geschiedenis der beschaving, een oppervlakkige waarneming van de lagere standen der maatschappij, een oogenblik nadenkens over het essentiëel verschil tusschen zingen en lezen, is, dunkt me, voldoende, om, de keuze van een middel te ontraden, dat nooit tot het doel leiden kan.

Op grond van al het hierboven-ontwikkelde meen ik der Regeering met aandrang te moeten voorstellen, om in het vervolg geen tembangs meer aan te nemen, maar enkel-prozawerken, en wel enkel zuiver-Soendaneesche. Moge de samenstelling aan den inlander, aan dien arbeid ongewoon, in den beginne eenige moeite kosten; het zeer aanzienlijke honorarium zal een voldoende spoorslag voor hem blijken te zijn om op het geregeld en ordelijk schikken zijner denkbeelden, het schrịjven van een dragelijken prozastijl, zich te gaan toeleggen. De ontwikkeling van taal en volk zullen hand-aan-hand gaan, en allerweldadigst op elkâar teruchwerken. Ln het geld der Regeering zal niet-langer worden uitgegeven voor hetgeen, ik ben er zeker van, in weêrwil van alle schoonschijnende rezultaten eenmaal zal blijken geen brood te zijn geweest.

Ik heb een tweede grieve tegen den vorm der door de Regeering uitgegeven Soendaneesche volksboeken, die ik niet mag verzwijgen; zij betreft het spelsysteem, dat, ik geloof het in weinige woorden te kunnen aantoonen, aan zeer tastbare gebreken lijdt en alles behalve navolging verdient.

Wat vooreerst de spelling van het Soendaneesch, ik bedoel: de schrijfwijze van de woorden met hun eigen, Javaansch- 
Soendaneesche, karakters betreft, die is omslachtig, onlogiesch, inkonzekwent, en in strijd met het wezen der taal. Op den voorgrond sta, dat van het Soendaneesch in dubbele mate geldt, wat Roorda van het Javaansch zegt: " de verdubbeling van een letter in de spelling kan voor de uitspraak geen beteekenis hebben, en daarom is zij ook in het algemeen af te keuren, uitgezonderd alleen bij de laatste letter van een woord, als het een aanhechtsel ontvangt, dat met een an begint." In twee zeer kardinale punten wordt van deze wijze les afgeweken. Terwijl men de verdubbeling van de an (onze $n$ ) in het midden van een woord, en terecht, als onnoodig wechwerpt, zoodat men b. v.

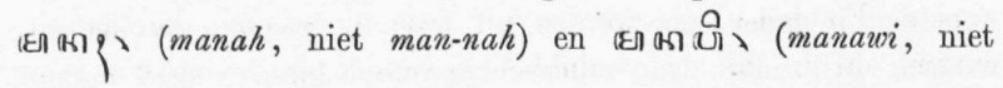
man-nawi) schrijft, gaat men daarentegen de verdubbeling van de [n (onze $n g$ ) in het midden der woorden bestendigen en tot

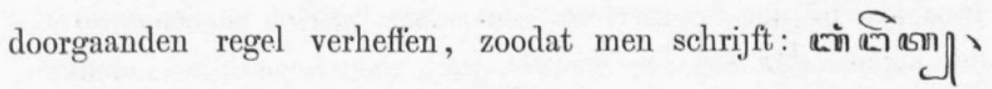

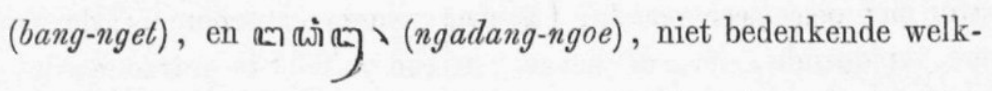
een schreeuende inkonzekwentie men daardoor begaat, en hoe. zeer men door die noodelooze verdubbeling het wezen van de nga miskent. En om de lánge pepet (waarvoor het Soendaneesch geen eigen klankteeken heeft) van de kórte te onderscheiden, ontziet men zich niet, na de korte pepet elken volgenden medeklinker te gaan verdubbelen, dat is met andere woorden: de afkeurenswaardige verdubbeling der medeklinkers systematiesch te drijven. Vooral dit laatste, het verdubbelen van den volgenden medeklinker, om aan-te-duiden, dat de voorafgaande pepet kort moet worden uitgesproken, is het toppunt van ongerijmdheid. Vooreerst is het een geheel-noodelooze nieuwigheid. De Soendanees zal, op het gevoel af, de beide klanken even-wiskunstig-zeker weten te onderscheiden, als de Engelschman zich zal wachten voor de vergissingen in de uitspraak van great $^{\prime}$ en read, ofschoon daarin de $e ́$ - en de $i$-klank op volkomen dezelfde wijze voor het gezicht worden afgebeeld. Ten tweede is in een groote menichte gevallen het fraaije verduidelijkingssysteem niet-eens uitvoerlijk; wanneer de pepet voorkomt òf in de la atste lettergreep van een woord (zooals b. v. in naker, pingges, antep en honderd anderen), ò in een gesloten lettergreep, wier sluitkonzonant on middelijk gevolgd wordt door een ánderen konzonant, (zooals b. v. in 
wengkè, serta, berkat) is aan verdubbeling van den op den pepet volgenden konzonant natuurlijk geen denken. Ten-derde ontstaat de schrikbarendste verwarring, doordien men in afgeleide woordvormen, om den vorm en de samenstelling van het woord aan te duiden, gewoon is, ook na een langen pepet, wanneer die in een gesloten eindlettergreep voorkomt, en het woord krijgt een aanhechtsel dat met een as bégint, den volgenden medeklinker te verdubbelen, zoodat men b. v. schrijft: कิง rechten strijd met de eigen manier van onderscheiding der beide pepets. En ten-vierde worden uit deze nieuwigheid barbaarschheden als b. v. de verdubbeling van de dja, waarvoor ieder inlander van eenige ontwikkeling zich wachten zal, wetende dat nooit een woord of lettergreep op een dja uitgaat, en de spelling van åxญang met een $b a$, een patèn, en wederom een

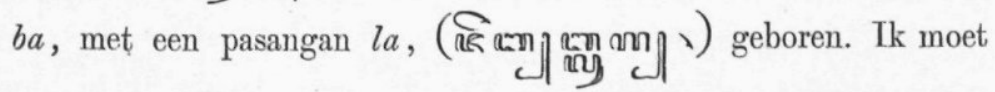
dan ook verklaren, dat naar mijne overtuiging de Regeering niet te spoedig met zoodanige ondoordachte, verwarde en verwarring veroorzakende spellings-theorieën breken kan, en dat men wijs zal doen met in hoofdzaak teruch-te-keeren tot het spelsysteem van Roorda voor het naauwverwante Javaansch. Eerst-dán zal de willekeur en ongelijkmatigheid, die in de spelling van het Soendaneesch noch heerscht, voor orde en regel plaats maken. Eerst-dán zal men een spelmethode hebben, die, terwijl ze voldoet aan den eisch van eenheid, eenvoudigheid en duidelijkheid, in harmonie is met het wezen der taal.

In de transcriptie van het Soendaneesch met Latijnsche letter schijnt men, zoo mogelijk, noch-ongelukkiger geslaagd te zijn. Om de tèlèng (een $e$, die nagenoech den klank van de eerste $e$ in het Fransche mère heeft) weêr te geven, gebruikt men een $e$ met een accent aigu, en schrijft b. v. béjak; en toen ik op het verkeerde hiervan opmerksaam maakte, toen ik ried om, op het voorbeeld van Roorda, den accent grave te gebruiken, die nu eenmaal (en om zijn half-liggende houding, niet oneigenaardig) in ons letterschrift den klank van de tèlèng afbeeldt, werd mij geantwoord, dat de accent aigu veel-meer overeenkomst heeft met de figuur van tèlèng dan de accent grave, en dat de Soendanees er daardoor veel spoediger aan wennen zou. Dit utili- 
VAN MR. D. KOORDERS.

teits-argument (op welks gegrondheid ten overvloede noch zeer veel zou zijn aan te merken), was voldoende, naar het schijnt, om bij de transcriptie van de tèlèng het klankteeken te kiezen, dat in het Latijnsche letterschrift den klank van de tèlèng niet weêrgeeft. Om de korte pepet van de lange te onderscheiden, bedient men zich van hetzelfde oneigenaardige en alleronvolkomenste hulpmiddel, waarvan hierboven, zoo ik meen, reeds genoech is gezegd. Met dit éene onderscheid echter, dat men in de transcriptie den verdubbelden medeklinker niet tweemaal schrijft, maar de verdubbeling enkel door-middel van een Doppelstreichen aanduidt. Een uiterst-willekeurig gebruik van dat letterteeken, den Duitschers, aan wie het ontleend is, ten-eenemale onbekend, en waarvoor zijn goede smaak den schrijver moest bewaard hebben. Een woord als bebekellan bv. geschreven, zooals men het schrijft (běb̌̌kělä), is letterlịk niet aan te rien. En het dubbele voordeel, dat er aan de overneming en algemeenmaking van het teeken zou verbonden zijn, bevordering van duidelijkheid en vermijding van omslag, bestaat louter in de verbeelding. Het is tastbaar, dat het woord goddelijk bv., op de gewone wijs met twee $d$ 's geschreven, het in duidelijkheid verre wint van god̄elijk met een Doppelstreichen in plaats van de tweede $d$, want de schrijfwijze met den Doppelstreichen vergt van den geest de moeite om zich een tweede $d$ voor te stellen, die er eigenlijk niet staat. En vermijding van omslag mag het voorzeker niet heeten, wanneer men zonder de minste noodzaak een nieuw letterteeken invoert, en noch-wel een letterteeken, dat het schrijven in zoo hooge mate vertraagt, doordien het de pen dwingt, telkens midden in een woord even op te houden en van rigting te veranderen. Ik zoek dan-ook de eigen lijjke reden, waarom de Doppelstreichen bij de transcriptie van het Soendaneesch opgenomen is, in iets anders; ik beschouw het als een onwillekeurig onvermijdelijk nitvloeisel van het systeem om de kórte pepet door verdubbeling van den volgenden medeklinker te onderscheiden van de lánge. Men begreep, dat het systeem zich zelf gevonnisd zou hebben, wanneer men (gelijk er in ons Hollandsch letterschrift toch eigenlijk staan moet) geschreven had: bebbekkellan en soemedjilja. Men begreep niet (ofschoon reeds de woordenlijst van de Wilde het had kunnen leeren) dat we de verdubbeling door-middel-van den Doppelstreichen volstrekt-niet noodig-hebben om, en dan nog op een tegelijk onooglijke en uiterst-onvolkomene wijs, aan-te-duiden, 
dat er een korte pepet voorafgaat; dat de heele zaak gevonden is, wanneer we de korte pepet afbeelden door onze gewone $e$ en de lange door een $\check{e}$ (de $e$ met een kapjen); dat we dan een allereenvoudigst onderscheidingsteeken hebben, dat zich laat aanwenden, ook-dáar waar het gekompliceerde hulpmiddel van verdubbeling en Doppelstreichen ons zou begeven. Het doet me leed ook in dit opricht een ongunstig oordeel te moeten vellen. Maar wanneer men zelfs de kleine moeite niet neemt van in de transscriptie, waar het tembangs geldt, ons stelsel van interpunktie toe-te-passen; wanneer men daarin geen-andere teekens gebruikt dan aan het eind van iederen regel een komma, en aan het eind van ieder koeplet een punt, zonder om hetgeen de $z$ in zou vorderen, zich in het minst te bekommeren; zou ik dan mijn plicht als ambtenaar, mijn roeping als wetenschappelijk man, niet met voeten treden, indien ik dit taalbederven vergoelijkend door de vingers zag?

Misschien van minder aanbelang, maar toch, naar ik meen, niet geheel van gewicht ontbloot, is een derde en laatste bedenking, die ik tegen den vorm van sommige Soendaneesche volksboeken heb; de bedenking namelijk, dat hel tegen-overelkâar drukken van den tekst met Javaansch-Soendaneesche en I atijnsche karakters nuttelooze, ja schadelijke geldverspilling is.

Het gros der bevolking kan niet lezen. Het is bedroevend, maar het is een feit; een feit waaraan niet valt te twijfelen, en dat ik me sterk mak, statistiesch te bewijzen. Onder degenen, die lezen kunnen, zijn maar z e e r weinigen, die het zoo-ver gebracht hebbeu dat ze, buiten het Arabiesche en Javaansch-Soendaneesche ook-noch het Latijnsche letterschrift lezen kunnen. Ook dit is een feit, waarvan ik me door navraag en proefneming vergewist heb. Is dan-wel de tijd reeds gekomen, om volksboeken (waarvan immers zeer aanzienlijke getallen worden opgelegd) in Latijnsch letterschrift te verspreiden? Kan de uitgave op dezen o ogenblik voor de ontwikkeling der Soendalanden nut van eenige beteekenis doen? Moet niet de oprichting en werking van goede distriktsscholen, waar ons alfabet geleerd wordt, voorafgaan? En zou het in-elk-geval niet verkieslijker zijn, de transscriptie a fzonderlijk te laten drukken? Zooals de zaak nú geregeld is, moet de kooper tweemaal hetzelfde betalen; de boekjens zijn zoo-veel-duurder, hetgeen natuurlijk nadeelig teruchwerkt op hun verspreiding, en de regeering kan uit het debiet niet opmaken, of werkelijk voor boekjens in ons letterschrift reeds een lezend 
publiek van eenigen omvang aanwezig is. Welk voordeel tegen die groote en onmiskenbare nadeelen overstaat, laat staan: er tegen opweegt, is me niet duidelijk.

Ik zou aan de Regeering wenschen voor-te-stellen, om voorloopig geen Soendaneesche volksboeken te laten drukken dan met Javaansch-Soendaneesche karakters, maar om ten behoeve der scholen van enkele, nader aan-te-wijzen, werkjens (in beperkter oplage) afzonderlijke transscripties in Latijnsch letterschrift verkrijgbaar-te-stellen. Dit zou, geloof ik, een vrij-aanzienlijke geldbesparing ten-gevolge hebben, zonder de minste schade voor de goede zaak. Bij de bestande regeling schijnt me niet genoechzaam gelet op het eigenaardig verschil tusschen school- en volksboeken. Men heeft denzelfden misgreep begaan, waaraan b. v. ik me zou schuldig maken, indien ik voorstelde om op-staanden-voet in alle Soendaneesche volksboeken met Javaansch-Soendaneesch karakter de woorden van elkaar af-te-scheiden en onze interpunktie in-te-voeren, omdat ik proefneming met dat systeem op de $\mathrm{kweekschool}$ allerwenschelijkst acht. Het plaatsen der transscriptie tegen over den JavaanschSoendaneeschen tekst schijnt me afkeurenswaardig, omdat het de gemakzucht van den leerling in-de-hand-werkt, en de kontrôle voor den onderwijzer verzwaart.

$\mathrm{Na}$ deze inleidende opmerkingen van algemeenen aard (die ik niet beknopter heb weten saam-te-dringen), ga ik thans over tot de mededeeling van mijn gevoelen omtrent taal en inhoud van

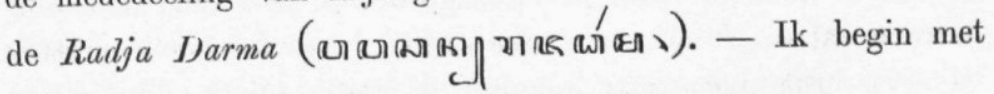
den inhoud.

Moest ik mijn oordeel daarover in éen enkele zinsnede uitspreken, ik zou het niet beter weten te zeggen dan met de woorden van Horatius: "desinit in piscem mulier formosa superne," ("eene van boven schoone vrouw loopt uit in een visch").

Het eerste gedeelte: de beschrijving van dien Patih, die zelfs tegenover 's Konings zoon zijn wettig gezach heeft doen gelden; van dien Prins, die zijn misstap erkent, en zonder morren zich op 's Patih's last naar de gevangenis laat brengen; van dien Vorst, die in-het-openbaar de handeling van zijn Patih goedkeurt en prijst; is ontegenzeggelijk goed en leerrijk.

Maar reeds de lessen, die de Vorst vervolgens aan zijn zoon geeft omtrent de plichten van een Regeerder (va. 73), worden 3e Volgr. IV. 
ontsierd door een stelling, die me toeschijnt een allerverderfelijksten geest te ademen, en in schrille weêrspraak te zijn met hetgeen men verwachten zou in een boek, bestemd om den zedelijken zin der bevolking op-te-scherpen. Zorg toch, zegt (vs. 74-76) de vader tot ziju zoon, dat ge altijd de hand houdt aan uw onderhoorigen, om in hun levensonderhoud en middelen van bestaan te voorzien: "want de kleine man bezit zoo verbazend weinich nadenken en hij is zoo-buitengemeen onnoozel, geheel anders dan de aanzienlijken, het verschil is geweldig groot;" zorg er toch voor, want doet ge dat niet, "dan is het eind, dat velen naar andere landen uitwijken." Ik vraag: kan de minachting voor den kleinen man als een soort van lager wezen in de schepping, die onbetwistbaar in het hart van de meeste aanzienlijken leeft, zich ruwer, onverholener, uitspreken? "Ik vraag: laat onzedelijker leer zich denken dan de hier gepredikte: doe het goede, want uw eigenbelang brengt dat mêe?" Onzedelijker in-zich-zelf, en ondoeltreffender tevens? Komen er dan niet gedurig momenten in het leven, waarin andere hartstochten de stem van het eigenbelang overschreeuwen? Geen momenten, waarin het eigenbelang mêebrengt om het kwade te doen en niet het goede?

Zoo echter de berispelijkheid van de Radja Darma zich tot deze enkele vlek bepaalde, het ware noch minder, die zou gemakkelijk wech-te-nemen zijn. Maar de verdere loop van het verhaal is van dien aard, dat het een doorgaande en stelselmatige bewierooking van de ondeugd wordt. Te-weten : als koning Darmat Madja zich door Soerasekti, den koning van Barat Madja, besprongen ziet, eindigt de Patih (die aan 's konings stervenden vader beloofd had, zijn troonopvolger te zullen trouw blijven) na moedig maar vruchteloos deu vijand weêrstand te hebben geboden, met zich een ellendigen lafaard te toonen; gevangen voor den overwinnaar gebracht, zegt hij (vs. 211): "ik bid Uw Majesteit, heb medelijden, laat me niet dooden, nacht en dag wil ik uwe Majesteit dienen." Hij laat het zich dan-ook aanstonds welgevallen, om zijn ambt uit 'soverweldigers hand teruch-te-ontfangen (vs. 212). Hij verraadt de verblijfplaats van zijn wettigen meester (vs. 213), en is daardoor oorzaak van diens gevangenneming. Hij ziet naar dien meester, die, opgesloten in een ijzeren kooi, een rampzalig leven leidt, niet om. Eerst-wanneer de willekeur van den nieuwen koning zóo-ondragelijk wordt, dat geen van de Rijksgrooten zijn leven meer zeker is 
(vs. 257); wanneer zij, uit beduchtheid voor hun leven, er toe komen om den dwingeland te onttroonen; herinnert de Patih zich zijn vroegeren Heer, wien hij trouw gezworen had. Maar geen spoor van berouw over zijn laaghartige handelwijs als hij in de gevangenis komt, en koning Darmat Madja zijn herstelling op den troon aankondigt. O neen! de schrijver schijnt het niet meer dan natuurlijk te vinden, dat hij zich voor het fait accompli heeft gebogen, of (om het in rond Hollandsch te zeggen) de huik naar den wind heeft gehangen. Hij is en blijft dan-ook de gevierde man. Alsof de zaak zoo vanzelf spreekt, behoudt hij zijn ambt; en een zoo-edelaardig man, zegt de schrijver, werd in-het-vervolg door koning Darmat Madja "noch inniger geliefd dan door zijn vader"' (vs. 299).

I $\mathrm{k}$ laat nu geheel in-het-midden of zulke uitgewerkte beschrijvingen van oorlogen en onttrooningen der vorsten door hun onderdanen (bijna twee-derde van het verhaal is er mêe gevuld) voor de ontwikkeling der Soendalanden nuttig en uit een politiek oogpunt bizonder-raadsaam zijn. Maar ik verg ten minste, dat de voorstelling der feiten niet gelijk in de Radja Darma het geval is, 's menschen grondbeseffen kwetse.... Volksboeken die zulk een geest ademen, die het onderscheid tusschen goed en kwaad opheflen, bevatten een kiem, niet van volksontwikkeling, maar van volksbederf.

Wat, in de tweede plaats, ta al en stijl van de Radja Darma betreft, ook daartegen heb ik gewichtige bedenkingen.

De taal is alles behalve zuiver-Seendaneesch. De maker gebruikt, deels ter-wille van voetmaat en eindklank, deels, naar het schijnt, uit bloote liefhebberij, allerlei uitheemsche woorden en vormen, zooals b. v. birahi, wewekas, kebir, noedjoe, toemengga, koemambang, ngèstikèn, rarahi, digdjaja, liněwih, kondoer, anarima, pragat, oeloessan, gerebeg, inggil, koemedap, sebah, enz. ja poenggawa en boepali gedurig in plaats van ponggawa en bopati.

De stijl gaat in matheid, waterigheid en onbeholpenheid alle denkbeeld te boven. Zoo zegt b. v. de maker in vs. 9: "'s Konings zoon was geweldig en geweldig, vervaarlijk en vervaarlijk, boos" (poelra radja liwat-liwat saking bendoena kabina-bina). Zoo in vs. 159: "Daar Vorst Radja Darma overleden is, treedt nu voor hem in de plaats, treedt voor den Vorst in de plaats, Zijun Hoogheid Radèn Darmat Madja, die hem vervangt als Vorst van Nagri Hindoe" (sabab kang Ijeng Rarlja Djarma 
enggěs poepoes, ajĕna anoe ngaganti, ngagenlos rama praboe, Kangrljeng Radèn Darmat Marlja noe goemanti djadi rarlja nagri Hindoe).

En, wat erger is, het boekjen is vol van baren en barrein onzin. Om zijn bepaalden eindklank en zijn afgepast getal lettergrepen te krijgen, heeft de maker zich niet ontzien, gedurig dingen neêr te-schrijven die geen taal zijn. Zoo spreekt hij van Prabangsa patih (evenalsof wij zeiden Willem Koning); van lampale (in plaats van lampahna) noe djadi radja (zoodat hij zegt: " de gedragslijn die Vorst is "); van marinkěn, dat niet bestaat (énkel maparinkěn); van koedoe pěntjit, voor koedloe dipèntjit (d. w. z. hịj moet dooden, hij moet gedood worden), en meer van die dwaasheden, die de taal en het gezond verstand beiden op de gruwelijkste wijze geweld aandoen.

Ware de Radja Darma proza, het kwaad zou misschien te verhelpen zijn. Ik zou dan aan de Regeering hebben voorgesteld om den tekst aan een algeheele herziening te onderwerpen; om in de lessen van den Vorst aan den zoon de noodige wijziging te brengen; en om met den dood van Radja Darma het boek te doen eindigen (iets waardoor het tegelijkertijd beter aan zijn titel zou beantwoorden). Maar nu de Radja Darma tembang is, waarin men gebonden is aan maat en eindklank, houd ik me overtuigd dat afdoende verbetering van taal en stijl tot de onmogelijkheden behoort; het zal lijm- en lapwerk blijven.

\section{RAPPORT No. II.}

Bandoeng, 31 December 1863.

Ten vervolge van mijn schrijven van 14 December jl. no. 12 zal ik de eer hebben alsnu der Regeering mijn gevoelen mede te deelen over taal en inhoud van de Dongèng-dongèng Toeladan

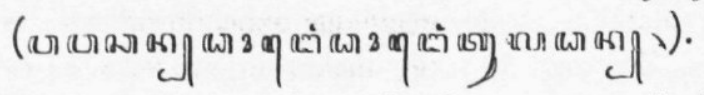

Wat vooreerst den inhoud aangaat, valt het volgende op te merken. Het eerste verhaaltjen (dat echter maar-elf pada's of koepletten groot is), hoewel zonder de minste diepte, en geen spoor van talent verradend, heeft een nuttige strekking; het kan veilig gelezen worden door groot en klein.

Van het tweede verhaal, de geschiedenis van Kertasana (zeven- 
en-tachtig pada's groot) zou ik dat niet zoo onbepaald durven verzekeren. De beschrijving van Kertasana's zwak voor de vrouwen, en vooral de toon waarop, de geest waarin dat ouderwerp behandeld wordt (pada 20 , en 41-43), schijnt me weinich geschikt om voor dat kwaad de oogen te openen, en in een schoolboek al zeer misplaatst. Daarbij de heele moraal van het stuk stuit me tegen de borst, het is een aambeveling van de deugd, enkel omdat men anders (zooals de maker in vs. 12 zegt) allicht matschappelijk-ongelukkig, " van rijk arm wordt." Karakteristiek is het dan-ook, dat Kertasana, als hij gereed staat zichzelf van het leven te berooven, geen berouw toont over de gruwelen, die zijn geweten bezwaren, maar enkel met spijt teruch denkt aan de dagen toen hij, als aankomende knaap, het bij zijn ouders zoo goed had, - toen hij "op alle mogelijke wijzen vertroeteld werd, ..... geld en kleederen hem in overvloed toevloeiden, en zijn woning een mooi planken huis was, prijkende met een begrind voorplein, terwijl op het achtererf aan rijk gevulde rijstschuren geen gebrek was." (vs. 89 en 90). Van wezenlijk schuldbesef geen spoor; hij gevoelt enkel, dat hij "door eigen schuld zich buiten de gelegenheid heeft gesteld van zijn vaders rijkdommen te profiteeren. "Ik geloof niet, dat zulke voorstellingen kunnen bijdragen tot hervorming van het zedelijk leven, de onmisbare voorwaarde van maatschappelijke herschepping. Maar gedachtig, dat de maker een inlander is (tegenover wien we onze eischen niet te hoog mogen stellen), en dat het stuk in elk geval een afmaning van het kwade behelst, wil ik op mijn bezwaren niet te zeer drukken. De "morale de la fable", dat men het rijsken moet buigen, terwijl het jong is, is onbetwistbaar goed; al betreur ik het, dat dat den ouders niet als zedelijke verplichting op het hart wordt gedrukt, maar met de drangreden, dat anders hun kinderen "hun geld zullen opmaken, ja hen vermoorden" (vs. 68).

Wat eindelijk het derde en grootste verhaal, de geschiedenis van Maratroena (honderd-een-en-zestig koepletten beslaande) betreft, het ademt een geest, dien ik allerverderfelijkst acht. Het predikt de leer (die de maker dan-ook in den aanhef, vs. 99, met ronde woorden uitspreekt): doe het goede, want "dan wordt ge van arm rijk, van gering aanzienlijk." Een leer, volkomen onwaar, en wier prediking reeds-dáarom allergevaarlijkst is; liefde voor de deugd, gekweekt door het openen van een bedriegelijk uitzicht op stoffelijk loon, heeft geen-enkelen waar- 
borg van bestendigheid. Maar een leer, dubbel-gevaarlịk omdat ze voor de edelste aller deugden, voor zelfverloochening en zelfopoffering, het gemoed onvatbaar makt; en omdat ze overmatige zucht naar rijkdom en standsverheffing, die bron van onheil voor individuen en volkeren niet intoomt, maar opwekt. Ze predikt den menschen zedelijkheid uit eigenbelang; daarmêe vernietigt ze in-den-grond alle begrip van plicht, met andere woorden: het wezen der zedelijkheid, en verheft ze, de piramide op haar top stellende, de laagste, dierlijkste drijfkracht van den mensch tot beslissenden toongever zijner handelingen.

En, alsof dit noch-niet genoech ware, komt er in het verhaal een epizode voor, waarin de laaghartigste verraderij wordt voorgesteld als een lofwaardige daad, die den dader rijke vruchten afwerpt. Te weten: Maratroena, die bekend-staat dat hij altijd op een voordeeltjen uit is (vs. 181), wordt door een Chinees aangezocht om, tegen een zeer aanzienlijke belooning, opium voor hem binnen te smokkelen. Hij neemt zich onmiddelijk voor, hem een strik te spannen ("niatna ngarlorlja," vs. 187); zegt daarom van-ja; en weet zoodoende den Chinees, (die aanvankelijk nochmaar in-het-algemeen van " een plannetje " had gesproken) zijn heele geheim te ontlokken. In-stilte verraadt hij nu alles aan den Wadana, en beraamt met dezen middelen om den smokkelaar te vangen. Maar tegenover den Chinees blijft hij, met een verwonderlijk talent, zijn dubbelhartige rol spelen, zóo-zelfs, dat hij dezen (die zich eerst wijselijk buiten schot had willen houden) beleest om mêe de opium van-boord te gaan halen. Het gevolg is natuurlijk, dat de Chinees gevangen wordt genomen. En de verrader? Niet alleen, dat hij "hoogelijk geprezen werd om zijn knapheid in het vatten van de smokkelaars" (vs. 224): maar hij werd door het Gouvernement ook-noch "beloond met een prachtige kris, in het goud gevat, en omzet met edelgesteenten." (vs. 225).

$\mathrm{Ik}$ zal hier geen woord bijvoegen dan alleen de vraag: wat moet er van een volk worden, wanneer men het gaat inprenten dat het doel de middelen wettigt?

Wat de taal aangaat, konstateer ik met genoegen, dat die veel onberispelijker is dan in de Radja Darma. Er komen in dit boek minder uitheemsche woorden voor, de zinbouw is minder gebrekkig, en de taal is meer die van het dagelijksche leven, hetgeen in een volksboek natuurlijk een groote verdienste is.

Dit neemt echter niet wech, dat ik noch vrị-wat heb aan te merken, gelijk uit onderstaande opgave blijken kan. 
[Ik acht het niet wenschelijk de lange lijst verbeteringen, in dit en volgende rapporten en die voor een groot deel het gevolg zijn van het opstellen in tembang-vorm, hier op te nemen. Alleen enkele opmerkingen, die meer de taal zelve betreffen, voorzoover ik er over oordeelen kan, laat ik hier volgen. M.]

Reeds de titel: Dongèng-dongèng toeladan is geen Soendaneesch. Het moet zịjn: Dongèng-dongèng tjonto.

Vs. 2 katiroe, niroe, moet zijn: katoeroettan, noeroettan.

" 6 Ngaringkel, moet zijn ngaringkoek.

" 17 Poetra lalaki, moet zijn anak lalaki of poetra pameget.

" 57 Ditalikoeng kan van de voeten niet gezegd worden. Diringlioes of dibarogod zou goed zijn.

Vs. 72 koelina, moet zijn boeboeroehna.

" 202 moendoer, " "balik.

" 218 istriman, " " djoeroe-moedi.

" 229 oetoesan. " " piwarangan.

" 256 diangkat " " didjenengkèn.

\section{RAPPORT No. III.}

Bandoeng, 4. Januari 1864.

Ten vervolge op mijn schrijven van 31 December $1863 . \mathrm{n}^{\circ}$. 13 heb ik bij-deze de eer, der Regeering mijn gevoelen mede-

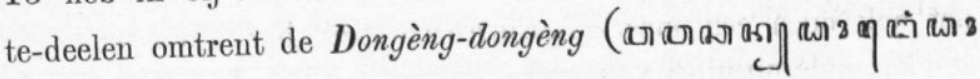
ๆ gedichten en fabelen", gelijk op de keerzijde van den titel staat maar) Europeesche fabelen, door den hoofdpangoeloe van Garoet naar een Maleische bewerking in het Soendaneesch overgebracht.

Het is me zeer aangenaam, den herdruk van dit fabelboek om zijn gezonde moraal en zijn echten volkstoon, onvoorwaardelijk te mogen aanbevelen. Ik zou op den inhoud niet-éene aanmerking weten te maken. Naar mijne schatting staat het in de rij der Soendaneesche volksboeken, die de regeering heeft aangegeven, bovenaan.

Ook de taal en stijl zijn, over-het-geheel genomen, onberispelijk: bij die van de Radja Darma en de Dongèng-dongèng 
toeladan steken ze allergunstigst af. De overgeblevene fouten zijn blijkbaar geen gevolg van onkunde; hoofdzakelijk hebben ze hun grond in de taalbedervende eischen van den tembangvorm, waarin ook dit boek tot mijn leedwezen wederom gegoten is.

Om de hooge waarde, die ik met het oog op de ontwikkeling der Soendalanden aan het boek hecht, komt me het allerwenschelijkst voor, dat er een afzonderlijke uitgaaf met Latijnsche letter van bezorgd worde, ten behoeve van de scholen. In proza overgegebracht, zal het een voortreffelijk leesboek zijn.

\section{RAPPORT No. IV.}

Bandoeng, 15 Januari 1864.

Ten vervolge op mijn schrijven van 4 dezer no. 14 heb ik de eer, bij deze der Regeering mịn oordeel meê-te-deelen over

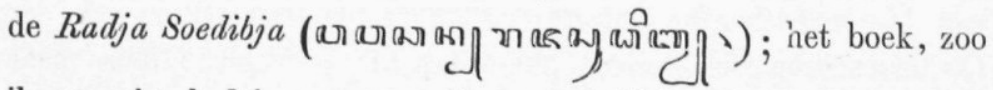
ik me niet bedrieg, voor welks vervaardiging de hoofdpangoeloe van Garoet met een gouden medalje is beloond.

Van den in houd heb ik gelukkig wederom weinich of niets te zeggen, daar die me over het geheel genomen, allezins lofwaardig toeschijnt. Het boek vloeit over van nuttige lessen voor de Regenten en andere inlandsche Hoofden; en tegelijk heeft het ook noch een meer-algemeene strekking, door namelijk, zonder ondermijning van godsdienstzin het bijgeloof, het hechten aan djampé's en andere bedriegerijen van dien aard, krachtig te bestrijden Onbetwistbaar is dit laatste een groote verdienste; ofschoon (dit moet ik er bijvoegen) van den Mohammedaanschen schrijver minder te verwonderen dan men oppervlakkig meenen zou, daar de bestrijding van zulke bijgeloovigheden in de richting ook van den Islam ligt

Bij den herdruk (die me, het spreekt wel vanzelf, wenschelijk voorkomt) zullen echter twee pada's moeten worden wechgelaten. Het zijn de verzen 505 en 506, die, letterlijk vertaald, luiden als volgt:

"Ook moet de Vorst niet-te-veel bijzitten hebben; het is te "vreezen dat hij er de hand niet aan zal kunnen houden, dat "ze liefdesbetrekkingen zullen gaan aanknoopeu met ándere 
"mannen, en ten gevolge daarvan hem in drift doen ontsteken. "Een tal van voorbeelden heeft dit bewezen. In Hindostan was "eens een vorst, die bijzitten bij honderden had. Doordien er "zooveel waren, kwam het er toe, dat ze niet-ieder haar beurt " of nacht kregen. Op het einde gingen de overgeslagenen over"spel bedrijven. De Vorst, dit ontdekkende, verdelgde ze; een "groote menichte menschen werden door hem gedood, zóo-zelfs "dat de stad bijna ontvolkt raakte. In de hitte zijner drift ver"gat hij, dat hij zelf van de heele zaak schuld was; dat hij "volstrekt niet voor de bevrediging van de natuurdrift zijner "vrouwen gezorgd had en dat de natunr van den mensch sexueele "gemeenschap van vrouw en man gebiedend eischt, evenals "zelfs in de dierwereld" (de heerschende wet is).

De goede bedoeling dezer regelen zal ik volstrekt niet ontkennen. Maar, hoewel in gewijzigden zin, ook-hier, dunkt me, geldt het spreekwoord: "le chemin de l'enfer est pavé de bonnes intentions." De ontucht wordt hier voorgesteld als een zeer vergeeflijk iets, als voldoening aan een onwederstaanbare behoefte van de menschelijke natuur; en de veelwijverij, die vloek der Oostersche maatschappijen, onbewimpeld gewettigd, mits ze maar binnen zekere grenzen blijve, daar anders uit een matschappelijk oogpunt nadeelige gevolgen te vreezen zijn. Zulk een leer moet, zoo-mogelijk, den zedelijken zin noch-verder helpen verstompen. Op naam van het Goevernement mag ze niet worden verkondigd. Oneindig beter, het kwaad onangeroerd te laten, dan het zóo te bestrijden.

Wat de taal van de Rarlja Soedibja betreft, die zal noodzakelijk een herziening moeten ondergaan. Ik ben zeer geneigd, om in dezen tembang, waarvan ik begrijp dat hij tembang blij ven moet, veel door de vingers te zien. Maar woorden als de, ieder oogenblik gebruikte, Javaansche Kawiwoorden: pramèswari, (radja atas) maroeta, roekmi, poera en poeri, sri maha (radja) sangkaton, sri nalendra, wikoe en mahavikoe, (mantri) panèwoe, djoerit, jang pertang gapati, rasmi, (djoeroe) telik, tepiswiris, wadja bala, pandii, ngampil en ampilan, mirong, prawira, tamtama, sarageni, maharesi, raspati, sawoeng galing, saoer paksi, maligè retna, wilis, kantjana en dergelijke zullen tóch door andere, Soendaneesche, vervangen dienen te worden; zelfs voor velen van de aanzienlijken zijn ze volkomen-onverstaanbaar, gelijk trouwens de pangoeloe zelf velen er van niet zon kenneu indien hij niet veel kennis van het Javaansch had. 
Ik wil nu net eens spreken van 's pangoeloes hebbelijkheid om onophoudelijk èndah, ngandika, prihalin (in den zin van kasoesahan), gagaman, moeni, gamelan, srengèngè, kalah, woewoeh, en meer andere Javaansche woorden van dien stempel te gebruiken, alsof ze in het Soendaneesch het burgerrecht hadden gekregen. Ik zal me maar troosten met de gedachte, dat die woorden ten minste voor de lezers van het boek versta a n ba ar zijn; dat ze waarschijnlijk ter wille van den dongding of eindklank vereischt werden, en dat uitheemsche w o or d en het wezen eener taal in veel mindere mate geweld aandoen dan uitheemsche woord-vormen. Ons hedendaagsch Hollandsch heeft minder geleden van den invloed dergenen die hun lezers plegen te vergasten op uitdrukkingen als b. v. "een sneer om de lippen" en "een Ahnung van ongeluk", dan door de taalbedervers die "onweêrzwangere wolken" en "sneeuwbeladen bergen" hebben binnengesmokkeld.

I $\mathrm{k}$ meen, met deze vingerwijzingen te kunnen en te moeten volstaan. Wilde ik koeplet voor koeplet alles opgeven, wat mijns inziens verbetering behoeft, ik zou der Regeering weder een zeer lange lijst met veranderingen kunnen voorleggen; maar om den tembangvorm van het boek zou de pangoeloe er zich toch niet aan kunnen houden. Ik wacht met de samenstelling van die lijst, tot ze mij uitdrukkelijk gelast wordt.

Ten slotte noch twee opmerkingen.

Vooreerst wensch ik aan het Goevernement in overweging te geven, om het barbaarsch-hybridiesche hoeppangoeloe, dat op den titel van dit en andere boekjens prijkt, te vervangen door het oud- en zuiver Soendaneesche pangoeloe gedè.

Ten tweede wensch ik te konstateeren, dat de Radja Soedibja door de groote menichte Javanismen (die onmogelijk allen kunuen wechgenomen worden) voor het eigenlijk-gezegde volk onverstaanbaar is, en ook wel blijven zal; hetgeen wellicht een beperkter oplaag dan b. v. van de Dongèng-dongèng verkieslijk maakt.

\section{RAPPORT No. V.}

Bandoeng 31 Januari 1864.

Ten vervolge op mijn schrijven van 15 dezer $\mathrm{n}^{0}$. 16 zal ik 
alsnu de eer hebben te rapporteeren omtrent de Woelang Tani

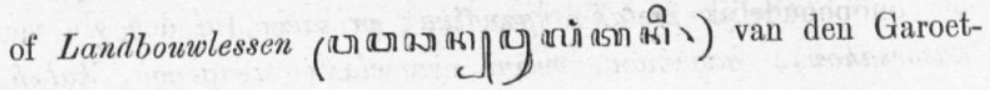
schen hoofdpangoeloe.

Tegen den herdruk van dit boekjen kan wel geen bedenking bestaan, wat de algemeene strekking van den inhoud betreft Het handelt over den aanplant van nuttige boomsoorten en gewassen; onder veel overtolligs, dat iederen kampoeng-bewoner minstens even goed bekend zal zijn als den schrijver, bevat het ook nuttige wenken en opmerkingen; en als zoodanig verdient deze eerste poging van den pangoeloe om de positieve kennis zijner volksgenooten uit te breiden, naar mijn bescheiden oordeel wezenlijken lof, al mis ik met leedwezen èn in den aanleg èn in de uitwerking de leiding van een Europeaan.

Onder het overtollige rangschik ik bovenal de, geregeld teruchkomende, opgaaf van hetgeen de vruchten en andere gewassen, waarover het boekjen handelt, op den pasar te Garoet plegen op te brengen. Wechlating daarvan zou ik zeer wenschelijk geacht hebben, vooral ook omdat het boekjen er een speciaal Garoetsche tint door gekregen heeft, alsof het uitsluitend voor de bevolking daar ter plaatse geschreven ware; iets wat, to oordeelen naar hetgeen ik hier te Bandoeng opmerkte, plaatselijke antipathiën schijnt op te wekken.

Zeer bevreemd heeft het me, noch van de pisang noch van de djagong of Turksche tarwe in het boekjen met een woord gerept te vinden. Twee gewassen, die onder de voedingsmiddelen der bevolking zulk een hoofdrol spelen, hadden hier, dunkt me, niet gemist mogen worden.

Een zonderlinge miskenning van de eerste beginselen der staathuishoudkunde is de raad om tjangkoedoe's (boomen, uit wier wortels roode verfstof bereid wordt) bij geheele bouws, en djeroeks bij honderden te planten, met voorspiegeling van behoud der tegenwoordige prijzen. Voorzeker zou bittere teleurstelling gevolg zijn, indien de bevolking in massa aan dien raad gehoor gaf. Gelukkig echter zullen, deels gemis aan energie, deels aangeboren gezond verstand, haar wel van dergelijke spekulaties teruchhouden.

Verdere aanmerkingen op den inhoud van de Woelang Tani heb ik niet. Alleen moet ik noch, last not least, in bedenking geven, of de wechlating niet raadsaam is van hetgeen in, vs. 8 en 9 over de verkieslijkheid van den landbouw boven den handel 
gezegd wordt, en luidt als volgt: "De handelaar is niet gelijk de landbouwer, vergenoegd van hart en vreemd aan logentaal. De handelaar kan iu den regel niet nalaten te liegen; dingen die $8 \frac{1}{2}$ cent waard zijn, beweert hij dat een waarde hebben van een gulden. Daarom is het veel-beter, landbouwer te zijn." Me dunkt, onder een volk als de Soendaneezen, welks ontwikkeling vertraagd wordt juist doordien het noch bijna uitsluitend een landbouwend volk is, moeten dergelijke scheeve voorstellingen worden bestreden, niet gevoed en bestendigd.

Wat de taal betreft, begroet ik in de Woelang Tani met blijdschap wederom een zuiver Soendaneesch boek; ontdaan van al die Javaansche en Maleische inmengsels, waardoor zoovelen van de door het Goevernement uitgegeven volksboeken ontsierd en onverstaanbaar worden.

Jammer maar, dat ook hier de zin noch zoo-dikwerf an de eischen van den tembangvorm is opgeofferd.

[Van de lange lijst verbeteringen laten wij maar een paar meer in 't oogspringende volgen. M.]

Vs. 110 moet worden: Diala papaganana, ngarah pakang aloes kër tali oesěp, djeng ngarah loengloemna. Tapi lamoen kawoeng ngora kènèh, tatjan poegoer, oelah diala pagagana; matak gorèng kawoengna, matak tě reà lahangna, enz. Althans, indien mijne bij verschillende landbouwers genomen, en door mijn inlandschen schrijver met een proef gestaafde, informaties juist zijn zou dit voorschrift van den pangoeloe veel overeenkomst hebben met de aanschrijving der Kamer van Zeventien om meer muskaatnoten, maar minder foelie te planten.

Vs. 129 mandalika bibit siki moet zijn: melak mandalika; koedoe sikina. - Zoo de mandalika, gelijk me van onderscheiden kant verzekerd is, de zuurzak is, zouden de woorden : tara lěbět boeahna; ngan oekoer poeloehan siki, als volkomen onjuist moeten wechvallen.

Vs. 212 zal keеr elat moesim, daar men volgens getuigenis van den Bandoengschen hoofdpangoeloe en anderen die uitdrukking niet bezigt, en ik dit gebruik van elat met de gewone beteekenis van het woord ook niet weet te rijmen, wel een stoplap zijn, die moet, en kan, wechvallen.

Het kan, dunkt me, der Regeering niet verwonderen, dat ik ten slotte wederom aankom met mijn "ceterum censeo Carthaginem esse delendum", vrij vertaald: "Voorts ben ik van oordeel, dat dit boek van zijn tembangvorm moet ontdaan 
worden." Waar (gelijk in de Woelang Tani het geval is) het opofferen van de zaken aan de eischen van den eindklank zoo ver gaat, dat bij de beschrijving der ananassoorten de zoogenaamde Hollandsche ananas wordt opgegeven als "afkomstig uit Oostindië" (asal ti India wètan), in plaats van Westindië, alleen omdat de schrijver in de eindlettergreep een a moet hebben, en dus het woord Koelon niet gebruiken kon; kan daar de noodzakelijkheid van overbrenging in proza noch aan twijfel onderhevig zijn?

\section{RAPPORT No. VI.}

Bandoeng, 11 Februari 1864.

Ten vervolge op mijn schrijven van 31 Januari jl. no. 18 heb ik de eer, alsnu aan te bieden mijn rapport betrekkelijk

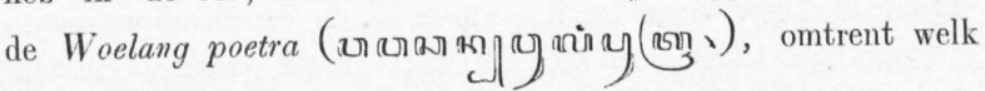
boek ik reeds vroeger (bij nota van 29 Augustus $1863{ }^{1}$ ) de vrijheid nam, zijner Excellentie den Goeverneur-Generaal eenige opmerkingen mede-te-deelen. Wanneer er geen andere keuze was dan tusschen onveranderden herdruk of niet-herdrukking van de Woelang poetra ik zou, reeds om de in genoemde nota ontwikkelde redenen, niet-herdrukking met den meesten ernst moeten aanraden. Want Mohammedaansche geloofsijver te helpen voortplanten, is naar mijne overtuiging niet de roeping eener regeering die een christelijk volk vertegenwoordigt en Nederlands heerschappij ove zijn Indiesche bezittingen wenscht te handhaven.

Doch gelukkig zie ik kans om, zonder-dat de eenheid van het boek daardoor verbroken wordt, het te zuiveren, van al hetgeen me toeschijnt niet met de goedkeuring en medewerking van het Goevernement onder de bevolking te mogen verspreid worden.

De veranderingen, die $\mathrm{ik}$ wensch aangebracht te zien (en die natuurlijk een samenhangend geheel vormen), zijn de volgenden:

10. moet in den aauhef van vs. 50 het woord ngadji vervangen worden door dagang zoodat een ambtelijke loopbaan, de landbouw, en de handel (niet-meer de bestudeering der theologie van den koran) daar genoemd worden als de drie hoofdberoepen, waartusschen de aankomende knaap kiezen kan.

1 Deze nota is niet onder de kopijen gevonden. M. 
2o. Moeten wechvallen vs, 51 tot en met 54 gedeeltelijk luidende als volgt:

"Wanneer ge aan de bestudeering der theologie van den "Koran" (wij zouden zeggen: aan de studie der theologie) "de "voorkeur geeft, word dan leerling van de oelama's. Zoolang "ge als santri onder hun leiding zijt, moet ge uw uiterste best "doen om hun hart te winnen. Volg den wil van uw leermeester "met volkomen overgegevenheid des harten op. Die leermeester "is, zoo-te-zeggen, uw heer en meester; en het is uw pligt, "hem lief-te-hebben, want dat ge het zoo-ver brengt van den "Koran behoorlijk te leeren lezen en zijn theologie te leeren "verstaan, hebt ge te danken aan het onderwijs van dien leer"meester. Leg u met de borst op uw studie toe, ten einde u "te bekwamen; laat $\mathrm{u}$ door de moeijelijkheden niet halverwege "afschrikken; wanneer ge u eemmaal al de lessen van uw onder"wijzer hebt eigengemaakt, zult ge, van de pasantrèn teruch"gekeerd, zekerlijk den zegen daarvan ondervinden. De pangoeloe "erkent $\mathrm{u}$, en neemt $\mathrm{u}$ om, in verbinding met hem, geschillen "over eigendomsrecht te berechten en uit-te"maken;" 1 en daarvan trekt ge zekerlijk vrucht. Hoe-langs "hoe-meer wordt uw bekwaamheid opgemerkt door de Grooten; "zekerlijk wordt ge tot pangoeloe verheven; ge oefent gezach uit "over lietibs en Modins" (priesters van minderen rang); ge "verzorgt en regelt den godsdienst; ge zit op een hooge plaats, "ge klimt in rang. Dat is de zegen van degeen die devotelijk "in den Koran studeert; hij zit te samen met le aanzienlijken."

3o. moet, dunkt me, vs. 57 wechvallen, gewijd aan wat ik zou wenschen te noemen een onzinnige rijstvergoding:

"Alle menschen zeggen, ten blijk hoeveel ze er van houden: "de rijst is de koningin der wereld, het voedsel van al wat "leeft. Haar wedergade zult ge, niet-licht vinden. Onfeilbaar "bezorgt ze u rijkdom en levensgenot."

De Regeering, vermoed ik, verlangt dezen schadelijken volkswaan niet opzettelijk te voeden.

4. moet om dezelfde reden, en bovendien om de ondubbelzinnige afmaning van den handel, die het bevat, het verhaal vs. 70 tot en met 84 wechvallen, waarvan de toepassing aldus luidt:

1 Ik heb deze woorden onderschrapt om er de aandacht op te vestigen met het oog op de kwestie van de toepassing van het Mohammedaanseh recht op Java. M. 
"Wie den landbouw beoefent, wordt ontwijfelbaar rijk; de "landbouw is een bron van rijkdom en levensgenot. Versta wèl "de leering, die er in het verhaal van den handelaar en den „landbouwer ligt opgesloten. De handelaar bezat veel schatten, "de landbouwer veel rijst; en het eind was, dat de handelaar "voor den landbouwer het onderspit moest delven. Al bezit men "menichte schitterende kostbaarheden, een groote hoeveelheid "paarden en koeijen en buffels, en men bezit geen rijst, men "zal zich op-den-duur zijn levensgenot niet gewaarborgd zien. "Rijst geeft kracht Rijst behoudt duurzaam haar glans."

$5^{\circ}$. Komt het me voor, dat de volgende beschrijuing van de voordeelen, die het schoolgaan afwerpt, niet boven bedenking verheven is (vs. 100 en 101):

„Buiten eenigen twijfel krijgen de Grooten u lief, roepen ze $\mathrm{u}$ tot zich, en worden $\mathrm{u}$ voordeelige betrekkingen gegeven, "door de gunst van uw Heer, ingevolge de voorbeschikking van "God den Allerhoogste. Wie zich met hart en ziel op het leeren "toelegt, wordt ten-langen-laatste door-middel-van zijn bekwaam"heid een welgesteld man, ja, een aanzienlijke (een mènak). "Dat is de vrucht van het vlijtig leeren. Men is altijd te ge"bruiken. Men is rijk door de giften van zijn Heer; men oefent "gezach uit over de onderdanen; men wordt zelfs beleend met "dorpen; men heeft macht om te bevelen; men helpt de in"komsten van zijn heer regelen; vele zijn de belooningen, groot "het leveusgenot, die men er op áarde van ondervindt."

Uit dat "men wordt zelfs beleend met dorpen" blijkt onwederlegbaar, wat ik in mijn nota van 29 Augustus 1863 reeds met een enkel woord zeide: dat namelijk al wat voor de zaak van het inlandsche schoolwezen gedaan is en wordt, door den schrijver wordt beschouwd en voorgesteld als het werk, niet van het Nederlandsche Goevernement, maar van zijn Heer, den inlandschen Regent. Het behoeft, dunkt me, geen betoog, dat deze grove onjuistheid, ook uit een politiek oogpunt allezins bedenkelijk, dient te worden wechgenomen.

Doch ook met die eenzijdige voorstelling der materieele voordeelen van het schoolgaan kan de Regeering, dunkt me, geen vrede hebben. Ze kwam wellicht te pas, zoolang het onderwijs als middel gebruikt werd om voor 's Lands dienst te vormen; ze moet ophouden, nu het onderwijs dienstbaar zal gemaakt worden aan volksontwikkeling. Dat men deze kindernenschen wijzen moet op het tastbaar voordeel, is ook mijne overtuiging, 
op het schoolgaan als de weg om vooruit te komen in de wereld. Maar laat men niet het ambtsbejach, een vau de verderfelijkste volksziekten, die hier reeds véel-te-endémiesch is, moedwillig aanwakkeren; het streven van den inlander er heen richten, om werktuig ja eenmaal lid te worden van de aristokratie; en verwachtingen opwekken, die zoodra het schoolgaan wat-algemeener wordt, voor de meesten zouden uitloopen op de bitterste teleurstelling.

$\left[\begin{array}{l}6^{0} \\ \text { en }\end{array} 7^{0}\right.$ zijn veranderingen voorgesteld bij wechlating van enkele stukken.]

80 acht ik niet-herdrukking van het volgende noodzakelijk (vs. 150 tot en met 162).

"De zangwịjs Midjil" (bevat onderrichting) "voor wie wenscht "te trouwen, opdat hij het doe met keunis van zaken. Ge moet "een vrouw hebben; maar ge moet tusschen vijf dingen kiezen, "aan welk daarvan ge de voorkeur geeft. Vooreerst een vrouw "van adel; een kind van iemand die een waardigheid bekleedt. "Ten tweede een vrouw, die een priesterdochter is. Ten-derde "een dochter van een rijk man. Ten-vierde een vrouw die mooi "is. Of ten-vijfde een die ree en knap is.

Hierna worden de voordeelen opgenoemd, die eene vrouw uit eene van de vijf genoemde kategoriën zal aanbrengen. Opvolging in een ambt; "veelheid van wetenschappen"; rijkdom en een rustig, zorgeloos leven; in een schoone vrouw "zal uw hart zich verheugen"; een "die ree is, zal uw leven veraangenamen". Zijn dat lessen voor het opkomend geslacht? Is dergelijk onderwerp geschikt om den inlander uit den staat van onzedelijke verdierlijking, waarin hij verzonken ligt, op te heffen? Mag onder de vlag van het Nederlandsche Goevernement een leer worden verkondigd, die het huwelijk tot een laaghartige spekulatie op stoflelijk voordeel verlaagt? Ik wil aamemen, dat deze stuitende epizode getrouw den geest weêrgeeft, die in de inlandsche maatschappij leeft. Reden te meer, dunkt me, om, nu de Nederlandsche natie haar lang verwaarloosde roeping tegenover de volken van den Indieschen archipel eindelijk terhand neemt, dien wangeest niet opzettelijk te gaan voeden. Maatschappelijke hervorming zonder zedelijke herschepping is bouwen op een zandgrond. En zedelijke herschepping wordt onmogelijk, indien de allerlaagste zelfzucht de drijfkracht is, die men in beweging tracht te brengen. Het is alsof men een zieke een gifdrank gaf. 
Ik heb me verplicht geacht, bij den inhoud van de Woelang poetra zoo-uitvoerig stil-te-staan, en van zoovele plaatsen een nagenoech-letterlijke vertaling in mijn verslag op-te-nemen, opdat het Goevernement met kennis van de zaak over de waarde mijner bedenkingen zou kunnen oordeelen.

In mijne aanmerkingen op de taal zal ik kort zijn.

Vs. 3 wordt loeas hier op Bandoeng niet verstaan; althans niet in den zin, dien het woord hier hebben moet.

Vs. 7 moet Pagoestèn, ons Godheid, een geheel-ongebruikelijke vorm, Goesti of Allah Toehan Allah worden.

Vs. 30 moet kipas worden sapoean.

Vs. 38 is niti soerti wellicht Garoetsch dialekt. Hier zegt men titi soerti.

Vs. 56 moet oepama het Javaansche minangka vervangen.

Vs. 67 moet masing, een schrijf- of drukfout, naar ik vermoed, worden: masih.

Vs. 106 is voor omong zeer verkieslijk bohong.

Vs. 112 is Kènana, schijnt het, Garoetsch dialekt. Verkieslijk ware: rasa manèh, rèanoe mertjaja, dunkt me.

\section{RAPPORT No. VII.}

Bandoeng, 4 Maart 1864.

Ten vervolge op mijn schrijven van 11 Februari jl. no. 19 heb ik de eer, bij deze aan-te-bieden mijn rapport omtrent de

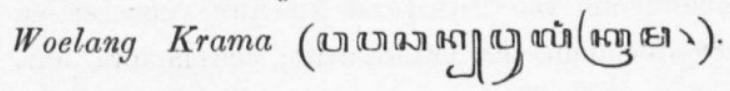

Wat den inhoud betreft, (die weinich heeft van hetgeen we gewoon zijn in het Hollandsch een "zededicht" te noemen), de langwijligheid daarvan heeft me bizonder getroffen. De pangoeloe ontziet zich niet, twee-, drie-, viermaal, nagenoech woordelijk, hetzelfde te zeggen; geheel in den trant van dien Rotterdamschen prediker, wiens "En Eli stierf, en hij brak zijn nek, en hij blies den laatsten adem uit, en hij was niet meer" noch in veler herinnering voortleeft. Het boek verschilt in dat 3e Volgr. IV. 
opzicht hemelsbreed van den "korten inhoud" indertijd der Regeering aangeboden, en ook aan mij in afschrift (ter inzage) mêegedeeld. Een paar proeven ten bewijze.

"Vierde kwestie. - Men behoort er zijn zinnen op te zetten, "om zijn zorgen wech-te-nemen als men zorgen heeft. Er zal "denkelijk wel een geneesmiddel voor zijn om dien drukkenden "last van zich wech-te-nemen. Welaan, neem ze wech, opdat "ze verdwijnen (vs. 6).

"Zesde kwestie. - De mensch behoort op zijn hoede te zijn. "Een onheil is wel eens-te-zien, dat noch-niet gekomen is. Even "als een betrokken lucht een teeken is, dat er regen zal komeu; "evenzoo is een onheil wel-eens" (vooruit-) "te zien. Zooveel in "uw vermogen is, moet ge op afwending van zulk een dreigend "onheil zinnen, opdat ge de moeijelijkheid moogt ontgaan, en "het dreigend onheil niet over u kome" (vs 9 en 10).

Lessen van levenswijsheid dienden, dunkt me, in genietbaarder vorm te worden gegeven. Vooral, wanneer de modellen die men (zonder ze te noemen) volgt, in een korten en zaakrijken stijl zijn gesteld. En bedrieg ik me niet, dan is dat hier het geval, dan is de Woelang Krama een navolging van Winter's Javaansche Darma Wasita. Ik werd onlangs in de gelegenheid gesteld, een Soendaneesche vertaling in proza van dat boek, afkomstig uit het Cheribonsche, met de Woelang Krama te vergelijken; en ik kon geen onderscheid opmerken, behalve dat het werk van den pangoeloe hier-en-daar een Mohammedaansche tint heeft gekregen, een meer-inlandsche moraal (gebazeerd op eigenbelang en gemakzucht) ademt, in tembangvorm is gegoten, en bij grooter omvang veel-armer van inhoud is.

Ik acht me verplicht, ook-daarom de aandacht der Regeering op die neiging van den pangoeloe tot omslachtigheid te vestigen, omdat het een, voor den Lande zeer kostbare liefhebberij is. Me dunkt, een honorarium van honderd gulden voor zestien bladzijden klein 80 Soendaneesch letterschrift; een honorarium, minstens vijf malen overtreffende wat aan mannen als van Oosterzee en Opzoomer in ons Vaderland wordt toegekend, en als men de gewone behoeften en inkomsten van een inlander in aanmerking neemt, een waarlijk verbazingwekkende som; zulk een honorarium is te hoog, om een dergelijke omslachtigheid te kunnen dulden........

Het spreekt overigens van zelf, dat het gezegde enkel een wenk voor de toekomst is, en niet om, nu het honorarium 
eenmaal betaald is, den herdruk van de Woelang-krama te ontraden. Ik voor-mij zou, om verschillende redenen, den voorkeur gegeven hebben aan de Cheribonsche prozabewerking. Maar ook die van den pangoeloe bevat menig voorschrift, dat behartiging verdient. Een nieuwe uitgave kan zelfs in tembangvorm misschien veel nut doen. Maar ik durf die niet aanraden zonder dat de inhoud enkele wijzigingen onderga.

Vooreerst moet vs. 23 worden omgewerkt, dat nu den ouders op net hart drukt om hun kinderen naar de priesterscholen te zenden. Ten tweede schijnt de inhoud van vs. 17 en 18 me allerberispelijkst. "Als er iemand is, die u het een of ander "vraagt, laat hem dan niet met geheel-ledige handen henengaan; $\ldots$. "De toekomst is voor $\mathrm{u}$ verborgen; het zou kunnen gebeuren, "dat ge gedwongen waart om ook te vragen. En dan zoudt ge "schande inoogsten.... men zou u stellig uitlachen, enz." $1 \mathrm{k}$ verg geen zuivere moraal, geen aanprijzing van de deugd om haar zelfs wil, die op den inlander geen vat heeft. Maar mag haar beoefening verlaagd worden tot een zelfzuchtige kansrekening? Is er dan geen middenweg? Kan men niet zeggen. Stel $\mathrm{u}$ in de plaats van den vrager: verbeeld u dat ge zélf in nood zat, en dat men $u$ hulp weigerde; hoe zoudt gij te moede zijn?

Ten derde mag de ergerlijke leer niet blijven, verkondigd in vs. 84-86: "'t Is beter een beleediging te vergeven, dan er zich warm over te maken, en alzoo zelf nadeel te lijden; althans als men geen doeltreffend middel kan vinden om de schande te vergelden."

Eindelijk moet uit vs. 177 het beroep op een uitspraak van nabi Isa ("den profeet Jezus") worden wechgenomen. Het is onvereenigbaar met het neutrale standpunt der Regeering door het Regeeringsreglement en de billijkheid voorgeschreven.

In de taal van de Woelang krama schijnen me de volgende verbeteringen absoluut-noodig.

Vs. 9 en elders acht ik voor prajalna, hier te Bandoeng ongebruikelijk, ialna te verkiezen.

Vs. 15 voor měntas, om diezelfde reden tas of bëtěng.

Vs. 22 stel ik, ter vervanging van het niet-Soendaneesche makè adjèn voor: aja rasrasan.

Vs. 51 zou ik voor jukin, een woord, dat ik ook in een 
Bantamschen tembang veelmalen gebruikt vond, maar hier weinich verstaan wordt, èstoe verkiezen.

Vs. 92 moet kabangkit, wellicht Garoetsch en stellig Bantamsch dialekt, zijn: kabisa.

Vs. 110 moet njela zijn ngahina. Te Bandoeng wordt tjela, njela niet verstaan.

Vs. 117 .... zuiverder Soendaneesch dan diwiraos is : dipiraos.

Vs. 171 stel ik wechlating van bingbang voor, dat, althans hier te Bandoeng, zelden verstaan wordt.

Vs. $196 \ldots$... Papa (in het Javaansch een synoniem van hina) wordt hier niet verstaan.

Vs. $205 \ldots \ldots \ldots-$ Ngaroeroeh, het Javaansche angloeroeh, verstaat men hier niet.

Vs. 235 zou ik voor sotja-sotja, hier ongebruikelijk, verkieslijk achten: mat $\approx$-mata.

Vs. 236 is voor kaloenta-loenta, geen Soendaneesch maar een Javanisme, naar men me verzekert, wellicht verkieslijk: toetoeloejan.

Vs. 300 is voor pakon, een Javaansch woord dat hier niet verstaan wordt, wellicht papagon verkieslijk.

\section{RAPPORT No. VIII.}

Bandoeng, 20 Maart 1864.

Ten vervolge op mijn schrijven van 4 Maart 1864 no. 23 heb ik de eer, bij deze aan te bieden mijn rapport omtrent de Djaka Miskin ( ฯ ช

De inhoud van dit alleronbeduidendst boekjen laat zich in weinige woorden samentrekken: Een arm man, niets anders bezittende, legateert bij zijn sterven aan zijn zoon een djampè, dat "loopen beter is dan stilzitten en opstaan beter dan slapen"; met aanmaning om die djampè enkel tegen vooruitbetaling van honderd rijksdaalders, te verkoopen. De zoon is zoo gelukkig, in een rijk Vorst een kooper te vinden. De Vorst is aanvankelijk van oordeel, dat hij een slechten koop gedaan heeft. Maar, op een nacht door slapeloosheid gekweld, staat hij op, verkleedt zich, en onderneemt een zwerftocht door zijn hoofdstad. Hij ontmoet een man, die bij den Patih wil inbreken; stelt hem 
voor om gemeene zaak te maken; wint daardoor zijn vertrouwen en komt zoodoende op het spoor van een samenzwering, door den Patih beraamd tegen zijn gezach. Met behulp van een scheermes, dat ze in het huis van den Patih vinden, weten ze dezen laatste in zijn slaap (zonder dat hij er iets van merkt!) de linkerwenkbraauw en de rechter helft van den knevel af-tescheren. En het eind van de geschiedenis is, dat de Vorst den volgenden dag den Patih laat onthoofden, den verkooper van de djampè, die hij thans weet te waarderen, tot Patih verheft; en den dief, die hem op het spoor van de samenzwering had gebracht, met een aanzienlijke waardigheid beschenkt. Een opwekking om tevreden te zijn met de betrekking, hoe klein ook, die men bekleedt, en oin te gehoorzamen aan zijn Goesti of Heer besluit het stuk.

Zeer gaarne zou ik tot herdrukking adviseeren; al ware het enkel-maar, omdat de Djaka miskin het éenige van de Soendaneesche volksboeken is, dat geen inwoner van Garoet tot maker heeft. Want mij is van verschillende zijden verzekerd, dat liet bij velen misnoegen verwekt, de aanzienlijke sommen, die het Goevernement bij voortduring voor de vervaardiging van Soendaneesche volksboeken uitbetaalt, naar Garoet te zien vloeijen.

Maar ................... na de bekrooning van den Garoetschen hoofdpangoeloe, omdat hij in zijn Radja Soerlibja het geloof aan djampè's bestreden had; na de uitgave, nu onlangs weêr, van de Geschiedlenis van Abdoerahman en Abloerahim, waarin op hetzelfde aanbeeld geslagen wordt; mag er, dunkt me, niet meer gedacht worden aan her drukking van een boek als de Djaka miskin, dat allezins bestemd is om den handel in djampès weêr in eere te brengen. Of hier al sprake is van een onschadelijke, ja nuttige, djampè, doet niets ter zake. De inlandsche bevolking zal onfeilbaar in haar voorliefde voor het ingeworteld kwaad bevestigd worden, als ze leest van een djampè, die voor verkooper en kooper beide zoo-uiterst-voordeelig was. Ze zal, op haar onontwikkeld standpunt, het met de soortelijke onderscheiding zoo naauw niet nemen. En het eind zal zijn, dat de bedriegerijen, die thans dag-aan-dag met die djampè's gepleegd worden, blijven voortduren; dat de heilzame invloed, dien de Radja Soedibja en de Geschiedenis van Abdoerahman en Abdoerahim tot bestrijding van schadelijk bijgeloof wellicht kunnen uit-

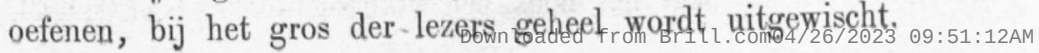


Met dubbelen ernst moet ik daarom de Regeering in-overweging geven, om de Djaka mïskin, als in lijnrechten strijd met hetgeen zij door de verspreiding van Soendaneesche volksboeken beoogt, NIET te herdrukken.........

Omtrent de taal van de Djaka miskin zal ik, in de hoop van onnoodig werk te verrichten, me tot enkele hoofdaanmerkingen bepalen.

Vs. 2 moet kalangkoeng zijn: kaliwat.

Vs. 4 moet weweling zijn: woewoeroek.

Vs. 6 moet patjoean zijn: papatjoean.

Vs. 12 moet prihatin zijn: ngenes of soeker.

Vs. 16 moet tepis wiring zijn: pasisian.

Vs. 20 moet papanggil zijn: kadiě.

Vs. 22 en elders moet voor emban; althans om een in Bandoeng gangbaar en verstaanbaar woord te bezigen, staan: oerang dalem.

Vs. $64 \ldots$ Voor perlampah, geen Soendaneesch, is lampahua verkieslijker.

RAPPORT No. IX.

Bandoeng, 2 April 1864.

Ten vervolge op mijn schrijven van 20 Maart jl. no. 25 heb ik de eer, bij-deze aan-te-bieden mijn rapport omtrent de T'jaritana (lees: tjarita) Ibrahim.

De titel van dit boek zal, bij eventueelen herdruk, noodzakelijk moeten gewijzigd worden. Hij is noch-véel-onjuister dan de titel: Tjaritra orang pamales (Gedicht over de luiheid) van de onvergelijkelijk-slechte Maleische rijmelarij, onlangs ter Landsdrukkerij verkrijgbaar gesteld, eu waarvan ik de uitgave, voor de eer van het Goevernement, diep betreur.

De geschiedenis van Ibrahim beslaat maar vijfeutwintig van de honderdtwaalf bladzijden, en dus noch-geen vierde gedeelte van het boek. Het moest heeten: Verhalen, fabelen en anekdoten, of iets dergelijks.

Tegen den inhoud heb ik geen bepaalde bedenking. Dat wil zeggen: ik acht het boek een volkomen-ouschadelijke 
lektuur .... maar ook dat er voor de ontwikkeling van taal en volk hoegenaamd-geen heil van te wachten is, alleen voor tijdkorting bruikbaar. Het staat natuurlijk niet aan mij, te beoordeelen, of het geld, dat de herdruk zal kosten, niet nuttiger zou kunnen besteed worden, b. v. voor de oprichting van een paar distriktsscholen. Hërnieuwde verspreiding van dit boekje zal geen kwaad doen; zoo geen gewichtiger belangen onder deze soort uitgaven lijden, kan de Regeering zich troosten met de gedachte: baat het niet, het schaadt niet.

Een paar geestigheden op bladzijde 110 ("Welk haar heeft het paard van den sultan van Madoera? Paardehaar" ; - en : "Waarom ziet een hond, op wien men schieten wil, om? Omdat hij geen oogen in zijn achterste heeft") zouden, dunkt me, gemist kunnen worden. Ze schijnen me niet zeer geschikt, om den inlander een hoogen durk te geven van Hollandschen spirit.

Ten slotte moet ik zeer ernstig adviseeren tot wechlating van den saïr, voorkomende op bladzijde 105-107. De inlandsche lezer zal er niets bij verliezen; want de zwevende, nevelachtige zin van het vers (zoo ik me niet vergis, een vertaling uit een der Duitsche dichters van de romantische Schüle), "als een galmend gerucht, rolt ledig zijn ziele voorbij." Een overplanting van den saïr der Maleijers op Soendaneeschen bodem is een zaak, waartoe mijns-inziens de Regeering de hand niet mag leenen. .......... Het invoeren van den saïr der Maleijers zou niets-anders zijn dan het openen eener nieuwe, mild-vloeijende, bron van taalbederf en zinledigen klinkklank. De taal, waarin de Tjarita Ibrahim geschreven is, komt me voor, beneden kritiek te zijn en gebiedend een algeheele omwerking te vereischen. Het boek maakt den indruk van opgesteld te zijn door een Europeaan....... Het wemelt van Hollandismen; van zinwendingen, waarin de uitdrukking van den zin der gedachte voor den inlander volkomen-onverstaanbaar is, ofschoon de gebezigde woorden allen zuiver-Soendaneesch zijn. De konstruktie is op vele plaatsen uiterst-stijf; en evenzoo vindt men op bijna-elke bladzijde fouten tegen de grammatika, waaronder zeer zinstorende.....

In een uitgewerkte opgaaf van hetgeen me foutief schijnt en van hetgeen ik daarvoor in de plaats zou wenschen te stellen, zal ik niet treden. Zulk-een opgaaf, zeer omvangrijk en tijdroovend, zou tóch maar een zeer betrekkelijke waarde hebben, doordien geheele omwerking vereischt wordt, en loutere 
wijziging van op-zichzelf-staande woorden en volzinnen niets zou zịjn dan een palliatief.

Ik zal me daarom vergenoegen met het meêdeelen van een drietal proeven, ten bewijze hoe weinich de vervaardiger van de Tjarita Ibrahim voor zijn taak berekend is geweest.

Vooreerst de titel: Tjaritana Ibrahim. Dit beteekent, in het oor van den inlander, Een verhaal van Ibrahim, in den zin waarin wij Hollanders van "Vertellingen van Vader Jakob" spreken. Doch dit bedoelde de vervaardiger niet; dit kon hij niet bedoelen. Tbrahim is niet de verhaler, maar de persoon over wien het verhaal handelt. Het is niet een verhaal, maar de geschiedenis van Ibrahim, waarmeê de lezer kennis maakt......

Tweede voorbeeld: het gebruik van boedak voor ons sla af in het derde verhaal, waardoor dat heele verhaal onverstaanbaar is geworden. Het is de geschiedenis van een Perziesch nangkoda, die door een fijnen vond van den rechter, wiens huip hij inroept, tegen de bedriegerij van een schurk gevrijwaard wordt......... Alles komt hier aan op de juiste vertaling van het woord slaaf. De Polyneziesche talen, waarschijnlijk omdat de instelling niet imheemsch is, hebben daarvoor geen eigen woord. De Suendanees behelpt zich met de omschrijving: djelma běnang měli (d. w. z. een mensch, door koop verkregen). In plaats hiervan gebruikt de vervaardiger boerlak; een woord dat zooveel als ons jongen, knaap beteekent: en maakt daardoor dat de gewone lezer van de geschiedenis niet-het-minste begrijpt. Derde voorbeeld: de vertaling vau ons afgetrokken begrip tijd door het basterdwoord: tèmpo. De Polyneziesche volken kenneu dat begrip niet, gelijk ze trouwens bijna-geen-énkel afgetrokkeu, en zelfs van vele dingen uit de zinnelijke wereld, zooals b. v. van dragen, geen algemeen of verzamelingsbegrip hebben. Ze hebben er dan ook in hun talen geen woord voor. Wie een zuiver-W estersche gedachte als: "verspil den tijd niet; tijd is geld" in een van die talen wil weêrgeven, kan derhalve niet slaafs vertalen; hij moet zich verplaatsen op het standpunt van den Polyneziër en de gedachte uitdrukken in den vorm, waarin deze haar met zijn voorstellingsvermogen bevatten kan. De vervaardiger van de Tjarita Ibrahim gebruikt voor ons tijd het Portugeesche tèmpo, dat in het Soendaneesch konstant de beteekenis, van een ergens voor gestelde tijd of termijn, en van uitstel heett. Zoo is hij er toe gekomen, 
om den onzin neer te schrijven: "Werp den gestelden termịnn niet wech; een termịnn is geld." Wie op zulkeen wijs den inlander tracht te ontwikkelen, komt me voor, met de beste bedoelingen van de wereld, niet-veel-verstandiger te handelen dan de beer, die, toen hij de vlieg op het voorhoofd van zijn vriend wou dooden, dezen met ziju klaauw het hoofd verbrijjselde.

Ik weet niet, of de Tjarita Ibrahim als leesboek op de Goevernementsscholen in de Soendalanden gebruikt wordt. Zoo ja, ik durf der Regeering de verzekering geven, dat het in ziju tegenwoordigen vorm enkel dient, om den inlander te versterken in zijn gedachteloos opdreunen van woorden en klanken, zonder om den zin en samenhang zich te bekommeren.

\section{RAPPORT No. X.}

Bandoeng, 17 Mei 1864.

Ten vervolge op mijn schrijven van 2 April 1864 n $n^{0}$. 26 heb ik de eer, bij deze der Regeering aan-te-bieden mịn rapport over het Soendaneesche rekenboek, kitab èlmoe itoengan (of, zooals de titel, foutief luidt: kitab èlmoe hitoengan). Over de waarde of onwaarde der in dat rekenboek gevolgde methode, met andere woorden: over het gehalte als leer- of schoolboek, kan ik geen oordeel uitspreken. Ik bezit den moed niet, om, op goed geluk af, over zaken waarvan ik geen kennis heb, mijn gevoelen te zeggeu; en dat bestudeering van de moeijelijke kwestie, in welken vorm en in welke opklimming men kinderen het best de eerste beginselen van lager onderwijs kan inprenten (een kwestie trouwens, wier oplossing naar mijne overtuiging niet uit boeken, enkel uit de praktijk te leeren is), nooit op mijn weg heeft gelegen, zal ik wel naauwelijks behoeven te zeggen.

De taal, waarin het boekjen geschreven is, heeft veel overeenkomst met het Fransch der vertaling van de Camera obscura, waarin meu b. v. onzen volksuitroep "Heere mijn tijd" door "Seigneur mon temps" vertaald vindt. Ik weet niet, waarover me meêr te verbazen: over de ạanmatiging of over de onkunde van den man, die zich aan de samenstelling van dit rekenboek gewaagd heeft. Van het begin tot het einde is 
het klinkklare onzin; een aaneenschakeling van Soendaneesche woorden tot volkomen-o nsoendaneesehe volzinnen, voor den inlander even-onverstaanbaar als Chineesch of Japansch. Het zij me vergund, met eenige weinige proeven, dit mijn, oogenschijnlijk wellicht eenzijdig en overdreven, oordeel te staven.

Niet eens de Soendaneesche benamingen van de vijf hoofdregels heeft de schrijver geweten. Voor aftrekken gebruikt hịj ngalaän, in-plaats-van njokot; voor vermenigvuldigen, in-plaats-van ngalarab, nikel (dat vouwen beteekent!) en, terwijl hij, voor deelen nevens ngabagi niet opgeeft het evenzeer gebruikelijke ngaïnkisar, zou hij ons willen diets maken, dat voor ons optellen, nevens ngadjoemlah, ook ngoempoel gebruikt wordt, en is met deze zijn dwaasheid zóo-ingenomen, dat hij op bladzijde 14, de regels van het optellen maar kortwech tot atoeran ngoempoelkěn verdoopt.

Ons met, waar het dient ter aanwijzing van het middel wa armeê of wa a rdoor iets gedaan wordt, dus in zijn oorzakelijke beteekenis, vertaalt de man geregeld door djeng, hetgeen ons met in een geheel-anderen zin, namelijk in dien van in vereeniging met, in gezelschap van, beteekent. Dit geeft natuurlijk aanleiding tot den belachelijksten onzin. Zoo lezen we b. v. op bladzijde 1: "In gezelschap van deze regels zijn de menschen in staat, allerlei berekeningen te maken" (ëlijëng atoeran ië djelma bisa mënangkěn saniskara itoengan); en op bladzijde 6: "De eigenwaarde van dat cijfer wordt vermeerderd in gezelschap van zijn plaats (harga dirina angka tèa ditamba, onzin die moet luiden: hargana angka sorangan tèa ditambak, ědjěng harga enggonna). Van de prépositie koe schijnt de schrijver nooit gehoord te hebben.

Voor ons eenheden, tientallen, honderdtallen enz. worden hier benamingen gebruikt, deels bestaande uit nieuw gesmeede woorden, deels nit woorden waaraan de Soendanees gewoon is een geheel anderen zin te hechten, zoodat hij zich b. v. (ik heb er onderscheiden malen de proef van genomen) maar niet kan voorstellen, hoe tien (sapoeloeh) tot de poeloehan of tientallen kan behooren. Dat de Soendaneezen voor de rangschikking der cijfers, althans tot acht toe, eigen benamingen hebben, waaraan hij zijn terminologie had kunnen en moeten vastknoopen, om verstaanbaar te schrijven, wist onze schrijver weêr niet. Trouwens ziju onkunde is zóo-verregaand, dat hij (terwijl laksa tienduizend en keti honderdduizend beteekent) 
de Soendaneesche schooljeugd wil leeren (op bladzijde 9), om in-het-vervolg de tienduizenden ketian en de honderdduizenden laksaän te benoemen.

Van dwaasheden als bv. atoeran in den zin van lijn, rị, regel; těndèn 6 dihandapěn enggon noe mimiti" (= zet de 6 onder de eerste plaats") in plaats van: noe 6 tëndén dihandapěn èka; sagala angka anoe salidiji $\mathrm{RAG \textrm {GAG }}$ dina enggon noe mimili" ( $=$ al de eénen vallen van boven naar beneden op de eerste plaats") in-stede-van: èka kabèh tënděn dina enggon noe panghelana sabelah li kaloehoe; mangka noe 0 èta gawèna paragi ngadjangkepkěn enggon baè" (= "wat de nul betreft, deze dient om de plaatsen toteen even getal te breng en), in-plaats-van: Ari nol tèa gawèna paragi nambahan harga baè; van deze, en duizend soortgelijke dwaasheden wemelt het boek. $1 \mathrm{k}$ durf beweren, dat er niet eene zinsnede dragelijk Soendaneesch in voorkomt. Het is wartaal van begin tot einde.

En niettemin wordt het kitab èlmoe itoengan, zoo ik me niet bedrieg, sints jaren op de inlandsche scholen in een deel der Soendalanden gebruikt, zonder-dat over de volslagen onbruikbaarheid zich ooit een klacht heeft doen hooren. Ligt in die hoe zal ik het noemen? onverschilligheid of overbescheidenheid? van den inlander niet een ernstige waarschuwing opgesloten om de samenstellers van lees- en leerboeken scherp op de vingers te zien?

\section{RAPPORT No. XI.}

Bandoeng, 28 Mei 1864.

Ten vervolge op mijn schrijven van 17 Mei jl. no. 32 heb ık de eer, bij deze aan-te-bieden mijn rapport omtrent het kilab Tjaljarakan soenda no. 1 (Soendasch spel en leesboekje met latijnsche letter door K. F. Holle le deel).

Over de meerdere of mindere bruikbaarheid van dit boekjen als spel- en leesboek voor eerstbeginnenden heb ik, op grond van mijn volslagen onbevoegdheid om dergelijke zaken te beoordeelen, me wederom tot den heer G. J. Grashuis gewend, wiens beschouwingen ik ook-ditmaal van genoegsaam gewicht 
acht, om ze als bijlage van mijn rapport onder de aandacht der Regeering te brengen.

I $k$ veroorloof me, die beschouwingen (die zich tot algemeene omtrekken bepalen), met de meest mogelijke bescheidenheid, naar de mate mijner kennis, op enkele punten aan te-vullen en uit-te-werken

Zoo schijnt me b. v. wechlating der op bladz. 5 voorkomende modellen van pijpletters en Gothiesche letters allerwenschelijkst. Ze zijn niet in ons hedendaagsch Hollandsch letterschrift gebruikelijk, ook in Indiesche dienstbrieven worden ze nooit gebruikt, en Soendaneesche boeken zullen er, naar ik vertrouw, wel nooit mêe gedrukt worden. Waarom dan de hersentjes der jonge Soendaneezen met dien ballast bezwaard en den leertijd er mêe verspild.

In no. 3 en 4 (op bladz. 6 en 7) zullen hra, tjra, lra, djra, jra, njra, ngra, aw, èv, ̀̀j, ij, iw, ow en oew dienen geschrapt te worden. In een "Soendasch spel-en leesboekje" behooren toch geen letterkombinaties te worden opgenomen, die men in geen enkel Soendaneesch woord aantreft, en waarvan een gedeelte voor den Soendanees zelfs niet uit-te-spreken is.

No. 5 (op bladz. 6), een opgave behelzende van tweeklanken, schijnt me toe, wederom geheel te moeten wechvallen. Ik dring hier op aan, omdat de hier gevolgde theorie op onbekendheid met het wezen van den tweeklank berust. Het Soendaneesch heeft, evenals het Javaansch, geen tweeklanken; niet-enkel de allerongelukkigste benaming sora dirangkep, hetgeen NB. verdubbelde klank beteekent), maar de zaak zelf is een splinternieuwe uitvinding. Een tweeklank ontstaat gelijk een kind weet, als twee klinkers tot een klank samensmelten (b. v. in ons uil en leugen); van dergelijke samensmeltingen is in het Soendaneesch geen sprake. $O j$ (niet oi dat in strijd is met de uitspraak en schrijfwijze der Soendaneezen, die b. v. tonggoj zeggen

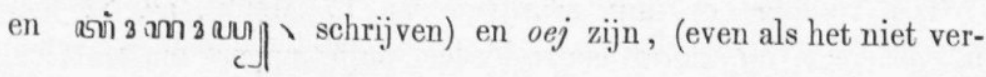
melde $a j$ en $\check{c} j$ ) samenstellingen van een vokaal met een mede-

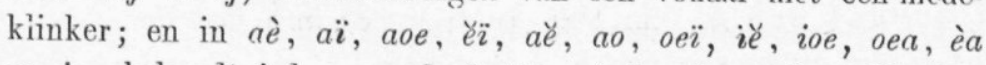
en $i a$, behoudt ieder van de beide vokalen haar eigen klank.

Het onderricht voor den onderwijzer ("arljiěn goeroe") op bladzijjde 14 vlgg. is, dunkt me, eigenlijk misplaatst in een leerboekjen voor de schoolkinderen. Dit is echter louter 
een kwestie van vorm. Doch daar komt bij, dat op de waarde of bruikbaarheid van den in houd zeer veel valt af-te-dingen. De nieuwgesmede benamingen voor onze zin-, lees-, en scheidteekens, gedeeltelijk uiterst-gebrekkig (zooals b. v. panggoegal, d. w. z. a anklager, voor ons a anhalingsteeken, en koma létik, d. w. z. kleine komma, voor ons komma), en allen bij den eersten oogopslag voor den inlander onverstaanbaar, worden door geen enkel voorbeeld opgehelderd. De omschrijving van den zin dier teekens is in vele opzichten beneden kritiek; zoo wordt b. v. van het af brekingsteeken enkel maar gezegd, dat het "dient om aaneen-te-hechten (zonder eenige nadere bepaling van het wát), en van de dubbele punt, dat het de pada is, die "de rede tot staan brengt.".......; terwijl geleerd wordt, dat men "na een punt en een dubbele punt" (?) "een groote letter moet gebruiken," zwijgt men er van, dat men b. v. na een vraagteeken hetzelfde moet doen. Ja, de zaken zijn in deze afdeeling met zoo-onverantwoordelijk-weinich zorg behandeld, dat de opgaaf van den inhoud der voorgaande afdeelingen bijna geheel-foutief is, zoodat ze alleen dienen kan om den onderwijzer in een doolhof van verwarring te brengen.

Het "1 1 ste deel" op den Hollandschen titel van dit Abcboekjen (want dát, niet "spel- en leesboekje" is de Hollandsche vertaling van kitab tjatjarakan) en het "no. 1" op den Soendaneeschen titel, schijnt me een lapsus calami, alleen verklaarbaar doordien de vervaardiger te veel aan ons Hollandsch woord leesboekjen heeft gedacht. Een tweede stukjen van dit, en van elk A bcboek schijnt me een ondenkbaar iets.

Ik neem deze gelegenheid waar, om (éens-voorál) te protesteeren tegen den woordvorm: "Soeudasch." Indien men, in strijd met alle analogie het adjectief niet verkiest af-te-leiden van den volksnaam (gelijk b. v. Javaansch van Javaan, Amerikaansch van Amerikaan, Chineesch van Chinees) en te schrijven: Soendaneesch, behoort men ten minste overeenkomstig den aard ven het Hollandsch taaleigen Soendaasch of Soenda'sch te schrijven. In Soendasch laat de $a$ zich niet-auders uitsprekeu dan b. v. in wasch.

Uit vrees van in te-groote uitvoerigheid te vervallen zal ik de $\mathrm{t}$ a alfouten, die ik in het boekje meen te hebben opgemerkt, maar niet éen-voor-éen nagaan en opsommen. Ik vergenoeg me 
met de algemeene opmerking, dat het, ook uit dit oogpunt, niet beantwoordt aan hetgeen ik gemeend had te mogen verwachten. Zoo wordt b. v. in no. 12 voor ons getuige in den zin van toevallig toeschouwer van iets zijn het woord njaksian gebruikt, dat een zaak als getuige bevestigen, geroepen getuige bij iets zijn, beteekent; een fout, nietminder-erg dan die van Boudewijn, toen hij The Lord's Supper door Mylord's soupé, in-plaats-van door Het Nachtmaal des Heeren, vertaalde. Zoo lezen we in no. 15, niet (gelijk de zin vordert) dat de Vader tot zijn zoon Sarman, maar dat hij tot den zoon van Sarman ("ka anakna Si Sarman," een oubestaanbaar wezen) zeide. Zoo in no. 12: silih nenggelan, in-plaats-van silih tenggelan, hoewel de neusklank van het werkwoord na silih altijd wordt weggeworpen.

\section{RAPPORT No. XII.}

Bandoeng, 30 Mei 1864.

Ten vervolge op mijn schrijven van 28 Mei jl. no. 33 heb ik de eer, bij-deze aan-te-bieden mijn rapport omtrent het kilab pikèn moerangkalih anoe mimiti diadjar matja Soenda (Soendasch spel- en leesboek met Soendasche letter, door K. F. Holle)

Het verheugt me zeer, dezen arbeid .......... gunstig te mogen beoordeelen. Geleidelijke opklimming, het hoofdvereischte en de hoofddeugd van een spel- en leesboekjen voor eerstbeginnenden, wordt hier niet, gelijk in het "spel- en leesboekje met latijnsche letter" gemist. De inhoud der leesoefeningen in aaneengeschakelde rede is met blijkbare zorg gekozen; geheel berekend naar de vatbaarheid van kinderen, en tegelijk er op ingericht om hun nuttige kennis in-te-prenten. Die leesoefeningen vallen niet, gelijk in het leesboekjen met Latijnsche letter het geval is, met de deur in huis.... Ik zou op de hier gevolgde methode geen aanmerking weten te maken; ik geloof, dat ze bij eventuëelen herdruk van het boekjen onveranderd kan worden behouden.

Ik haast me echter hier bij-te-voegen, dat mijn ingenomenheid met het boekjen haar grenzen heeft; dat mijn gunstig oordeel niet geacht moet worden, zich tot al de onderdeelen uit-te-strekken. Integendeel; ik heb, speciaal wat de ta al betreft, zeer gewich- 
VैAN MR. D. ḰOOKDERS.

tige bedenkingen, die ik me verplicht acht met eenige uitvoerigheid te ontvouwen.

Vooreerst zijn hier (op bladzijde 5 tot 8 ) weêr allerlei letterkombinaties opgenomen, die geen Soendaneesch, die gedeeltelijk voor een Soendanees niet uit-te-spreken zijn : @ (

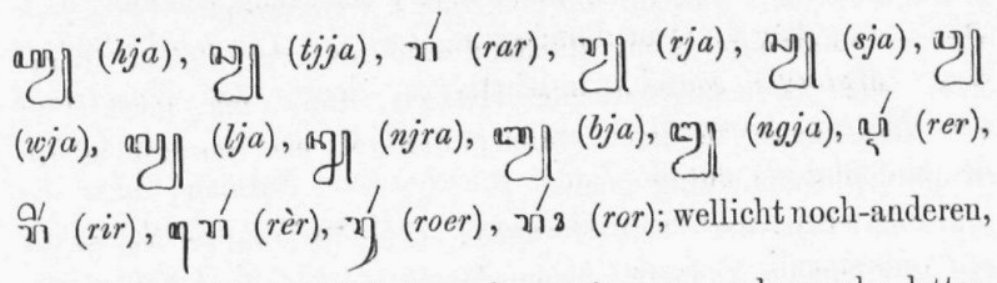

die ik over het hoofd heb gezien, zijn on soendaneesche letterverbindingen, die in een Soendaneesch spelboekjen niet mogen geduld worden.

Onder de pada's of scheidteekens zijn (op bladzijde 3) zeer ten-onrechte ons vraagteeken en uitroepteeken opgenomen. Ėvengoed zou men een of twee van onze Hollandsche letters in het Javaansch-Soendaneesche alfabet kunnen overbrengen. Zoo iets gaat natuurlijk niet aan. Het is een geheel-ándere kwestie (gelijk ik de eer had, reeds in mijn rapport van 14 December 1863 $\mathrm{n}^{0}$. 12 op-te-merken), of het niet mogelijk en wenschelijk zou zijn, ons heele systeem van zin-, lees- en scheidteekens der Soendaneezen, ook bij het gebruik van hun-eigen letterschrift, te leeren. Maar het verraadt verregaande onbekendheid met het wezen der pada's in de Polynéziesche talen, daaraan een paar van onze zinteekens te gaan toevoegen, die, juist omdat ze zinteekens zijn, in het systeem dier pada's, bloote scheidteekens, volstrekt niet passen.

De aksara gedè of hoofdletters, waarvan op bladzijde 3 opgave geschiedt, en van wier gebruik op bladzijde 14 eenige voorbeelden worden gegeven, zijn, volgens hetgeen me van verschillende zijden verzekerd is, en ik ook uit handschriften heb meenen op-te-merken, met uitzondering van de ga ditjoerek (die dan echter, ook in dien vorm, de funktie niet vervult van aksara gedè) in de Soendalanden ten eenenmale ongebruikelijk. Wil men ze den kinderen leeren, omdat ze in Javaansche stukken zoo dikwerf voorkomen, uitmuntend; maar men voege er bij, dat het zuiver-J a va ansche lettervormen zijn.

De benaming sandangan (op bladzijde 3) is een Javanisme. Het Soendaneesch daarvoor is rarangkèn. 
(nder de pasangans of aanvoegletters mis ik met groote bevreemding de $C$ en de $Q$, beiden algemeen ia zwang: en de laatste zelfs (met uitsluiting van de vorm 느) in de handschriften, die ik bezit, de éenig-gebruikte.

De beteekenis van de, op bladzijde 3 voorkomende, benaming aksara panambah is mij duister; even als verschillende inlanders, wien ik haar voorlegde. Het zal, dunkt me, goed zijn; een klassifikatie te laten varen, die tot een onverstaanbare terminologie aauleiding geeft.

In de taal der leeroefeningen, eindelijk, vallen een reeks van grootere en kleinere onnaauwkeurigheden te verbeteren. Zoo moet b. v. op bladzijde 15 wechvallen: "sagara dèèt batan laoet, laoet djero batan sagara"; het is onzik, even-groot, als of een Hollander zeide: "de zee is ondieper dan de oceaan, de oceaan is dieper dan de zee." Zoo is op bladzijde 17 warna, in den zin van ons begrip kleur, voor den inlander volkomen onverstaanbaar. Zoo is op bladzijde 27, en elders, voor sato-sato verkieslijk: sasatoan. Zoo klinkt de rangschikking, op diezelfde bladzijde 27, van de visschen onder de sato lěwěng of wilde dieren wel eenigzins-zonderling. Zoo is de spelling van taûla met een pangwisad volkomen-foutief, en alleen uit onbekendheid met het $\Lambda$ rabiesch te verklaren. Zoo zijn uitdrukkingen als Goesti noe lěwih oeninga (pag. 28) en Goesti noe kawasa Hollandismen; de inlander zegt enkel Goesti Allah of Allah taâla. Zoo is een zinwending als narljan koemaha lemboetna èta baè, voor: hoe $\mathrm{klein} \mathrm{dat}$ ook $\mathrm{zijn} \mathrm{moge,} \mathrm{een} \mathrm{stijve,}$ slaafsche navolging van een Hollandsch modèl; de Soendanees zou zeggen: sakoemaha baè lemboetna. Zoo .... doch waar zou ik ophouden, indien $\mathrm{ik}$ een gespecificeerde lijst van al de vergrijpen tegen het taaleigen woû geven? Het meêgedeelde zal wel voldoende zijn, om te doen zien, dat de lof, dien ik aan de in het boekjen gevolgde methode heb toegezwaaid, op de taal niet van-toepassing is; dat deze-laatste noch op vele plaatsen verbetering behoeft, zal het boekjen wezenlijk bruikbaar worden. 


\section{RAPPORT No. XIII.}

Bandoeng, 31 Mei 1864.

Ten vervolge op mijn schrijven van 30 Mei jl. no. 35 heb ik de eer, bij deze aan-te-bieden mijn rapport omtrent het Kitab tjonto-ljonto soerat (of gelijk het twee bladzijden verder heet: Kitab soerat-soerat tjonto) pikèn moerangkalih anoe iskola djisid $\mathrm{n}^{0}$. 1 (Soendasche modellen vau verschillende brieven, door Holle.)

Dit brievenboek is, naar het me voorkomt, met weinich oordeel samengesteld, en zat bij eventuëelen herdruk geheel dienen omgewerkt te worden.

Vooreerst passen $\cdot n^{0}$. 50 en 51 , zijnde een vertaling van de "Voorloopige bepalingen omtrent het beleid van de justitie en politie in de afdeeling Sindjai", op Celebes (St. $1860 \mathrm{n}^{0}$. 44) en van de "Instructie voor de districtshoofden op Java en Madura" (St. 1859 no. 102) zeer zeker niet in een boek met brievenmodellen. Ik laat daar, of het gelukt is, onzen ingewikkelden, omslachtigen wetstijl overal even-trouw en evenverstaanbaar in het Soendaneesch weêr-te-geven. Ik wil aannemen, dat in de lektuur van die "Voorloopige bepalingen omtrent het beleid van de justitie en politie in de afdeeling Sindjai" een, mij tot-heden raadselachtig nut schuilt. Ik ontken niet, dat vroegtijdige bekendmaking der aanstaande distriktshoofden met hun Instruktie wellicht haar nut kan hebben. Maar ik beweer, dat dergelijke stukken niet in een Brievenboek behooren te worden binnengesmokkeld. Laat alle dingen eerlijk en met orde geschieden.

Ten tweede is het de voorliefde voor tembangs toch watvér drijuen, dat de inleiding (bladzijde 3 tot 5 ) in tembangvorm is opgesteld....... Dat een inleiding in proza oneindig-meer in harmonie zou zijn met den uiterst prozaïschen inhoud van een Brievenboek, zal wel geen betoog behoeven. Dat zulk-een proza-inleiding, die niet gedachteloos kan worden opgedreund, maar tot nadenken noodzaakt, ook daarom de voorkeur verdient, is, dunkt me, middagklaar.

Ten-derde is de taal, waarin de brieven vervat zijn, een bont mengelmoes van Javaansch en Soendaneesch......... De dwaze, taalbedervende, gewoonte der Soendaneesche aanzienlijken, om hun brieven met Javaansche woorden te doorspekken; hun voor de toekomst van het Soendaneesch allerschadelijkst, voor- 
oordeel, dat een Javaansch woord veel fatsoenlijker klinkt, dat het onvermengd gebruik van hun moedertaal alleen den kleinen man past: wordt er door bestendigd. Dit kan de bedoeling van het Goevernement niet zijn; veelmeer zou ik durven beweren, dat het er meê in lijnrechten strijd is. Tk vlei me dan-ook, dat de Regeering tot herdrukking van het boek niet zal overgaan, voordat het door herziening tot een modelboek van zuiver-Soendaneesche brieven vervormd is.......

Ten-vierde en laatste schijnt het me zeer wenschelịk, dat aan de brieven in Javaansch-Soendaneesch letterschrift een evenredig getal worde toegevoegd, met latijnsche letter gedrukt. Dat we, indien het ons ernst is om de Soendaneezen met ous Hollandsch alfabet gemeenzaam te maken, hun speciaal het gebruik daarvan in hun brieven moeten leeren, is duidelijk. Maar waarom dan in dezen brievenbundel niet opgenomen, wat er eigenaardig in thuis behoort; wat een van de krachtigstwerkende middelen tot algemeenmaking van ons letterschrift zou blijken te zijn?

En hiermede is de taak, mị door de Regeering opgedragen, ten-einde.

Ik heb getracht, haar zoo-goed en zoo-spoedig als me, bij mijn noch zeer beperkte kennis van het Soendaneesch, mogelijk was, af te werken.

Niemand kan minder voldaan zijn over mijn arbeid dan ik-zelf.

Maar éen ding ben ik me bewust: dat het namelijk mịn streven geweest is, de waarheid, de volle waarheid, en niets dan de waarheid te zeggen. 


\section{AANTEEKENINGEN OP EEN REIS DOOR ZUID-BANTAM.}

31 Mei. Vertrek van Bandoeng.

1 Juni.... Weêr prachtig weêr; kwart over zevenen vertrek ik naar Soekaboemi. Een schilderachtig mooije weg over het zadel van den G. Gedè, rechts voortdurend, bijna tot Soekaboemi toe, diens in wolken gehulde kruin en welig beplante voetglooijing, links steeds het Kendang-gebergte in-het-verschiet. Tusschen Tjiandjoer en den eersten post (Waroe, of Waroeng? Kondang) het voorstuk van mijn wagen in groot gevaar, doordien een van de paarden met zijn achterpoot over den boom springt (ngalangkah bom) en, met dien poot den grond niet rakende, met zijn heele zwaarte op den boom komt te liggen, dien hij door zijn trappen en slaan stellig zou verbrịjzeld hebben, zoo alle-man niet geholpen had om ventre-à-terre de paarden uit te spamnen. Toch avarij, die we echter eerst te Soekahoemi ontdekken.... Tusschen $\mathrm{T}$ ji Roempoet (den derden post) en Soekaboemi, aan de brug over den Tji Moentjang, vernieling van de Sasak 1 waarmeê mịn wagen overdekt is, doordien het dak van de brug aan den Oostkant te-laag is, en de sasak, in de volle vaart van het rijden, tegen zoo'n karambole niet bestand is. Aankomst te elf uur bij d'A.... Afbranding der werkplaats van een ijzersmid; kennismaking bij dien brand met den wadana, een flink man.... Wandeling door de distrikt hoofdplaats (pakěmitan).... De erven en wegen in de kampoengs uitmuntend in orde; kuilen hier-en-daar aanwezig ter verzameling van mest. Overal welvaart en tevredenheid uit voorkomen en kleeding blijkbaar (zooals trouwens den héelen weg van Tjandjoer af, langs).

2 Juni.... De wadana deelt me mede, dat er te Soekaboemi geen-andere tembangs onder de bevolking in-omloop-zijn dan twee of drie Javaansche, die weinigen verstaan, maar om te "menjanji" altijd goed zijn. Tegen schemeravond vertrek naar Karang Tĕngah (9 paal). De nieuwe militaire weg alles behalve vrij van up and downs. We passeeren drie redelijke rivieren, geen-

1 Sasak wordt meest in de beteekenis van brag gebruikt. Hier zal het een kap van gevlochten bamboe zijn. 
van-allen noch met steenen bruggen voorzien, den Tji Goenoeng, den Tji Pèlang en den Tji Koekoeloe.... Het wordt onderweg stikkedonker, zoodat ik reeds van de pakĕmitan Tjimahi, waar we doorrijden, niets meer zien kan, en ter naauwernood het hooge gebergte kan onderscheiden, dat links van den weg gedurende het laatste gedeelte van den weg me dreigend tegengrijnst. De wadana van Tji Hělang vraagt nieuwsgierig met welk doel ik naar Bantam ga en verzekert me, dat buiten Junghuhn, noch-nooit iemand langs dezen weg Bantam is ingedrongen. Trouwens v. K. zeide me gisteren al, dat, volgens hetgeen hem was meêgedeeld, van de Bantamsche grens af tot Madoer geenandere weg is dan een smal en onbegaanbaar voetpad. Nu, dit zal de tijd leeren; bovendien, mij prikkelen zulke moeijelijkheden, ze verhoogen mijn genot en energie.

3 Juni. Om half vijf op weg naar Palaboean Ratoe op een magnifieken Makassaar, maar ongelukkig wat zwak op de pooten, lělěs soekoe. Prachtig weêr, prachtig berggezicht, links op den boomloozen Goenoeng Walad, rechts op den G. Panendjoan, vooruit op den Batoe Toeri. De zeer slingerende weg is in den beginne $(3,4$ palen ver) zeer mooi, vlak en gemakkelijk, maar reeds door onbewoonde streken, vol kaso en ěri 1 loopende. Na het passeeren van den Kampoeng Tji Mèntèng komen we aan den G. Batoe Toeri, (links van den weg, die over zijn zadel henenloopt), welks uiteinde de grens is der districten Tjihělang (waar ik uitkom) en Tjimahi (dat ik nu binnenrijd); drie distrikten voorzien er zich uit van kalksteen. De vrij-breede, met donderend gebruis voortstroomende Tji Tjatji, wiens bronnen (sirahna) op den G. Ki Salak ontspringen, vertoont zich een eindjen vóór den G. Batoe Toeri uit, rechts van den weg. Daarachter de G. Kasoer. We passeeren sukcessievelijk, door de zoo-goed-als-onbewoonde streek voortrijdende, nú steil op, dan steil af, den Tji Mèntèng, den Kampoeng Tji Angsana (uit één huis bestaande) daarna het riviertjen van dien naam, vervolgens den Tji Djambè waar zich rechts de pasir ${ }^{2}$ Djambi vertoont, twee waroengs, en komen zoo eindelijk aan den Tji Tjatji, een 4 dĕpa diepe rivier (mịnn schrijver zegt: hij heet Tji Tjatjik), die men op een sasak kambang ${ }^{3}$ (in deze streken bandoengan genaamd) oversteekt. Een eenzame waroeng staat

1 Kaso Sdnsch. = glagah; èri zijn doornstruiken. (M.)

2 Sdn. heuvel, kleine berg.

3 Snd. vlot of pont, op twee schuiten. (M.) 
an de Tjimahische zijde der rivier (want aan de overzijde begint Palaboean Ratoe). Men is nu Limapal (5 paal) van Karang Tèngah. Het boomlooze landschap wordt hier voor een oogenblik afgebroken, doordien links de, overigens slechts met gras bedekte en heuvelachtig-oploopende glooiwanden der rivier, die het gezicht begrenzen, met een lachend groepjen welig-groenende boomen begroeid zijn. We komen door den Kampoeng Tji Noetoeng en krijgen de rivier van dien raam in het oog. Van het Kendenggebergte is nu niets te zien, doordien de pasir Tji Noetoeng hem onderschept. Prachtig is, als men den Kampoeng Tji Noetoeng een eindtjen voorbij is, rechts het gezicht op den lang-uitgestrekten Pasir Pinang Gading, en daarachter, in een ver verschiet, op den hoogen G. Oenoet. Links van den lemboer 1 Tji Gombong vertoonen zich weêr, als een oaze in deze woestenij, enkele boomgroepen, waar het vermoeide oog met welgevallen op rust; rechts houdt men den Oenoet altijd in het gezicht; vooruit en links wordt de horizon, zoover het oog reikt, begrensd door het trotsche Kendeng-gebergte. We passeeren vervolgens Tji Langkap en den waroeng Kiara. Daarna begint de, ongelooflijk-steenige, weg over den naakten Pasir Baĕd te loopen, (waarna hij, tot-aan de brug over den Tji Tjarěh, Tanjakan ${ }^{2}$ Baĕd heet.) Vóor de brug ligt de kampoeng Gèntong; de weg daarheen, over de heuvelhelling naar omlaag, glooit langzaam (njangsaja, in tegenoverstelling van pontèng, montèng, steilomlaag loopen). In deze streken (waar men slechts enkele tipars en hoema's ${ }^{3}$ ziet) kost de $t$ jaèng ${ }^{4}$ padi gemeenlijk, op zijn goedkoopst $f 15$, op zijn duurst $f 20$; hier en daar was nog al soeoek ${ }^{5}$ geplant, die veel beloofde. Als men de Tji Tarĕh is overgegaan, rijst, steil maar trotsch, rechts van den weg, de pasir Tji Djambè omhoog, prachtig met boomgewas begroeid, van den top tot-aan den voet links, de weiwich-hoogere, G. Boetak; de Tji Tjarěh-zelf heeft zijn stroombedding in een breed en diep ravijn waar-de vegitatie recht-tropiesch is. Na de rivier Tji Djambé aan gene zijde van den pasir Tji Djambè (over wiens heuvelhelling de weg loopt, die tot-aan de brug over die rivier tanjakan Tji Kembang heet) te zijn overgegaan,

1 Rigg: lumbur, Holl. dorp.

2 Rigg: an ascent, a hill on a road etc.

3 Jav. tegal en gaga. Ml. ladang.

4 Een gewigt van 1000 katis.

5 Sdn. voor Ml. katjang tanah, Holl. aardnoot. (M.) 
ziet men te midden van een eindeloos getal ándere bergen en heuvels, voor zich uit den, enkel met gras bedekten, pasir Moentjang. Even-vóor Bantar Gadoeng bracht de weg ons door den kleinen kampoeng Pasapèn (welks tegalvelden Karang Sapèn heeten). Zoo bereikten we eiudelijk het, 13 paal van Karang tèngah liggende, Bantar Gadoeng, waar ik me haastte aan den pasanggrahan af-te-stappen. Ik was tamelijk-vermoeid; het was bij twaalven, de reis was dus niet voorspoedig geweest, deels door de groote bezwaren van den weg, deels door de brandende zonnehitte in deze kale onherbergzame landstreek, die reeds om zeven uur hinderlijk begon te worden. Bantar Gadoeng ligt in een kleinen dalkom, het is er warm. - ..... Het dorpjen, vol vruchtboomen en te midden van een kleine uitgestrektheid sawahs gelegen, maakt een gezelligen, aangenamen indruk. Hier ontdekte ik voor-het-eerst (wat me later, oòk in Palaboean het geval bleek te zijn) dat men het inlandsche hoofd, hetwelk in rang op den palinggi (die ónder den ljamal, sahandapěn tjamat, staat) volgt, en op zijn beurt den panglakoe onder zich heeft, niet loerah of roerah, maar kvewoe noeint.

Den Tji Bantar Gadoeng (waarvan de brug reeds-tweemaal in weinige jaren is wechgeslagen) moesten we doorwaden (njoektjroek);.... Aan de overzijde der rivier slingert aanstouds de weg zich weêr, even-steenig als vroeger, omhoog; tusscheu den pasir Pogor (rechts) en den pasir Malang (links). We passeeren den kampoeng Tji Sěsĕpan, daarop den kampoeng Pangaïran, den waroeng Bodjong galing, den Tji Djarian en aan diens overzijde den kampoeng van dien naam, van-waar-uit de weg weêr dadelijk klimt, over den met eenig houtgewas begroeiden pasir Soerèn zich henenslingerend. Op een terreinverheffing, waar we links van ons den pasir Kiwara zagen liggen, werd me voor-het-eerst, in de verre verte vooruit, over den G. Djajanti (recht vóor ons) en (iets-meer-rechts) den G. Rĕma heuen, door mijn geleide de zee gewezen. Ze vertoonde zich als een valblaauwe, bijna loodkleurige streep aan de kim, een scherp kontrast vormende met de donkergroene Urwälder van den Djajanti en den Rĕma..... Na den Tji Kawini gepasseerd te ziju, en bij den Tji Gombong (dien we links zich door een diep en rijk begroeid ravijn zagen heenslingeren) op nieuw de zee in het oog gekregen te hebben, veranderden de woeste weg en de wilde natuur eensklaps van voorkomen. We reden over 
zwarten, mullen grond, aan weêrskanten met boomen beplant, en vau het hooge punt, waar we links den Tji Gombong aan onze voeten zagen liggen, ..... vertoonde zich (rechts van den weg), voor-het-eerst na ons vertrek uit Karang tèngah, weêr een echt-Oostersche kampoeng aan ons oog, omringd door sawahs en half-verscholen tusschen wuivende kokospalmen. Het was de kampoeng gobang 1 Tji Loa. Iets-verderop (links) lieten we den kampoeng Tji Korèd liggen, gingen de rivier vau dien naam met een brug over, en kwamen zoo-eindelijk aan de bedding der breede en snelstroomende Tji Tarik, die we met een sasak kambang overstaken. Aan den overkant dier rivier ligt de kleine kampoeng Tji Boeaja, dien we door moesten; vervolgens leidde onze weg ons sukcessievelijk door den kampoeng Tji Kadoe, over de kleine riviertjens Tji Bolang en Tji Lĕngsi, (welke laatste, rechts van den weg komende, zich in den ter linkerzijde voortbruisenden Tji Tarik uitstort) en door den kampoeng Tji Lĕngse. Even-voorbij dien kampoeng kwamen we den G. Geplak (links) en een met boomen mooibegroeide streek (rechts) langs. De mooije kampoengs Tji Pitjoeng (links), daarachter (méer links noch) Tonjoug, een eindtjen verder (eveneens links) Nagrog omzoomden en vervrolijkten een verder gedeelte van ons pad. Bruggen brachten ons vervolgens over de, zich in de Tji Tarik uitstortende Tji Logawa en Tji Gadog. Over deze-laatste gekomen, dwong ik onwillekeurig mijn paard tot stilstaan, getroffen door het gezicht (rechts van den weg) op den G. Djajanti, die zich, van deze zijde gezien, voordeed, als uit drie stukken bestaande, alle drie van boven tot ouderen met ondoordringbare bosschen bedekt. Als men den kampoeng Tji Saäd (rechts van den weg) voorbij en de rivier van dien naam over is, krijgt de weg, weêr stijgende over den pasir Tji Saäd, en weêr met rolsteenen bezaaid, tot-aan het uiteinde van den kampoeng Tji Barèngkok den naam van Tanjakan Tji Saäd. Naauw is men dien kampoeng door of links van den weg ziet men den breeden Tji Maniri (die hier den Tji Tarik reeds in zich heeft opgenomen) zijn zilverkleurige wateren tusschen boorden, begroeid met trotsch geboomte, naar zee stuiven, hier met donderend geweld, ginds rustig-kabbelend als een beek. Men moet zoo-lang door dor en waterloos hoogland gereden hebben, als ik toen gedaan had,

1 De beteekenis door $R$. gegeven past hier niet. 
om het welddadig verkwikkende en verfrisschende, dat in het aanschouwen van dien zich door lage boorden voortkronkelenden stroom gelegen was, te kunnen bevroeden. Tegelijk met den Tji Maniri vertoonde zich, rechts van den weg, de Tji Boeria, een klein winterstroompjen, welks wateren (s'il y en a) zich in den grooten slokop, den Tji Maniri (de eenige van al die rivieren, die tot zee doorloopt), uitstorten. Al verder gaande, den grooten kampoeng Tji Djajanti door, komt men vervolgens weêr in een bij-uitstek woeste streek, waar de weg zich tusschen den hoogen G. Djajanti (rechts) en den niet minder hoogen G. Tangkoeban Parahoe (links), die geheel den vorm van onzen Bandoengschen Tangkoeban Parahoe heeft, al dalende met naauw merkbare glooijing, henenslingert. Op een kleine paal afstands van de plats onzer bestemming passeerden we den kampoeng Tji Tjangngègar, en naderden we (tegen vijf uur 's middags) Palaboean. De gezichteinder was aan alle kanten door bergen begreusd; van Palaboean en van de zee was geen spoor te ontdekken, zoodat mijn schrijver en ik gedurig teleurgesteld aan onze geleiders vroegen, of ze zich in den ofstand niet vergisten. Ik had me, op gezach van A., den heelen warmen en vermoeijeuden dag lang, getroost met de gedachte aan het prachtige gezicht, dat men op ḋrie kwartier afstands van Palaboean, na het neêrdrukkende van uren lang bergen en niets dan bergen, hoogland en niets dan hoogland aanschouwd te hebben, heette te wachten. Maar helaas! van dat vreedsame gezicht, voordat men in drie kwartier tijds een vijftien-honderd voet daalt, op het in een dalkom aan zee liggende Palaboean en de stille wateren van de Wijnkoopsbaai genoot ik niet; en wel om de eenvoudige reden, dat ik den gewonen weg en niet van Soekaboemi af door Djampang koelon gegaan was.

Plotseling, bij het omdraaijen van een hoek, bevond ik me in Palaboean, een lange, rechte rij van huizen, met een breeden weg er tusschen door; weldadig was het gezicht op de wuivende palmen en de, voor de woningen neêrhurkende, menschengroepen; maar mijn illuzie was vervlogen, mijn hooggespannen verwachting verijdeld, van de zee (waarvan ik later vernam, dat ik noch 13 minuten verwijderd was, en waarvan ik enkel het dof geklots tegen het strand kou onderscheiden) was, hoewel ik de rechte straat, die ik doorreed, ten einde tuurde, geen zweem te ontdekken; en met een wrevelig gemoed stapte ik aan den pasanggrahan af. Deze ligt, zooals ik zeide, 13 minuten 
van zee, als men de bovengenoemde straat omstreeks-halfweg is, aan den aloen-aloen recht-tegenover de, onder lachend groen bevallig verscholen, en tegelijk, door de witte muren, schilderachtig uitkomende woning van den Europeschen pakhuismeester. Het is een vrij-slecht en bouwvallig gebouwtjen.

Daar mijn paardrijden, bijna 12 uur lang, in de brandende zon, up and down, door een woest berglandschap me tot mijn verbazing niet had vermoeid, wandelde ik tegen schemeravond met den pakhuismeester en zijn vrouw naar het strand, ten einde naar het visschen te kijken, dat door zijn menschen daar met een soort van zegen geschiedde. Glooijend als te Katwijk en Scheveningen loopt de oever van duinzand hier af; en als ik recht voor me uitstaarde, den onmetelijken Stillen Oceaan in, was het me te-moede alsof ik weêr thuis was, en de Noordzee zich aaน mijn voeten uitspreidde; maar zoodra ik het oog ter zijde wendde, links naar de hooge bergen van Djampang Koelon, rechts naar de niet-minder hooge Bantamsche bergen, die de inspringende Wijnkoopsbaai begrenzen, en naar de naakte klippunten rechts, waarover onophoudelijk witte stuifzeeën heenrolden, voelde ik weêr, dat ik me niet in Holland bevond, hoewel dit besef me waarlijk niet minder vatbaar maakte voor 'den indruk van het goddelijk-schoon panorama, dat me te zien werd gegeven.

Van 5 tot 10 Junij ontbreken de aanteekeningen.

Den 11 Junij bevond K. zich te Bajah (?) aau de Preangerzijde van de Tji Barènoh. Eenige beschrijvingen van den weg door Zuid-Bantam mogen hier wederom volgen.

11 Junij...... De koewoe verklaart, dat hier nooit Europeanen geweest zijn, met uitzondering van (in 1855) een njonja, reizende van Soekaboemi naar Bantam. Aan den overkant, in het Bantamsche, wordt de rivier, bijna zoover het oog reikt, begrensd door den hoogen, langen, met ondoordringbare bosschen (maar met voetpaden tot boven toej bedekten pasir Mangga. Tusschen de rivier en dien G. ligt het Bantamsche Tji Barènoh (welvarend). Tusschen den, van het Preanger Tji Barènoh uit gerekend, linker uiteinde van den pasir Mangga en het, als men zich omkeert met het gezicht naar achteren, naar den G. Bodas, rechter uiteinde van den G. Bodas, stroomt de Tji Barènoh in zee. 
's Avonds vaart op een bandoengan (zoo geheeten, omdat er geen tali hò̀ 1 is, waar langs de pont wordt overgetrokken, anders èrètan) de Tji Madoer, breed en kristalhelder, met lage groene boorden als een Hollandsche rivier (maar hier-en-daar suelstroomend met steenbanken) af naar zee, meestal tusschen de prachtigste boomgroepen, zich welvend over het water, een enkele maal afgewisseld door een troep vreedzaam grazende buffels. De tocht duurt meer dan een half uur, eer we aan zee komen, maar verveelt geen oogeublik door de goddelijk-schoone gezichten, vooral aan den linkerkant op den G. Madoer, zich met zijn groene bekleeding uitstrekkende tot in de rivier. Aan zee vlak-strand en daarvoor woeste branding, wel een kwartier ver, met (links, vlak bij ons) den scherp in zee vooruitstekendes, maar ook-hier even-welig begroeiden uithoek van den G. Madoer (antjol Madoer) en (rechts) een bij het vallen van de avoudschemering zich flaauw, maar toch blaauw tegen den horizon afteekenenden, lang-uitgestrekten, ver in zee vooruitspringendeu (van hier te zien), G. Tjihara. Dáar noch-weêr vooruit hemelhooge branding te zien. Teruchvaart. De bocht, waar de Tji Madoer zich van de G. Madoer afwendt om door de smalle dalstrook te stroomen, waarin Bajah ligt, vertoont zich op korten afstand noch, door de hier bij uitzondering als stroomzand oprijzende rotsblokken, wier omtrekken door het overwelvende loofdak niet scherp te onderkennen zijn, als de ingang van een grot.

12 Junij..... N. van Bajah ligt de K. Babakan aan deu hoogoprijzenden oever, tegenover een eilandtjen, door de rivier (Tji Madoer) gevormd, schilderachtig, met bamboe begroeid. Bajah ligt in een kom, begrensd teu O. N. W. door bergen, O. door G. Madoer (N. N. O. naar Z. Z. W.); N. door pasir Loa en pasir Lĕwih Malang (N. N. O. naar Z. Z. W.) en pasir Tji Karatjak (O. naar W.). Daarna taalonderzoekingen met den Demang.....

13 Junij. Door slagregens en donderslagen gewekt. De Tji Dikit gisteren noch laag, helder en vrij kalm, nu zijn bruingeel-gekleurde wateren met woedende vaart naar zee stuivende; vlak tegenover ons valt een zware boom van den oever in de rivier, met een vreeselijk geweld, tegen half zeven. Spoedig daarna vertrekken we. De Madoer met een sasak over. Daarop

1 hoè, Rigg: hoih, rotan, dus touw van rotan. Vgl. bl. 52 onderaan. 
misschien $1 \frac{1}{2}$ paal rijzen en dalen binnen door. Vervolgens langs eentoonig strand, overal met pandau en bakoeng 1 omzoomd. 3 paal van Bajah de Tji Koempaj, 3 gardoehuisjens; 5 minuten verder de ondiepe Tji Moenggoel Asěpan (breed), 5 minuten verder spitse rotspunten op strand en in zee. Altijd door pandan. Een eindtjen verder de Tji Mangpang. Merkwaardig, de bedding dier beide laatste rivieren ligt lager dan het duinzand; 6 paal ver gekomen, komen we aan den vrij breeden, 10 à 12 voet diepen Tji Mantjak, die op zijde vam ons tusschen groen geboomte door komt stroomen, zich na een eindtjen met een bocht gestroomd te hebben met den Tji Siih, die van den anderen kant, parallel met het strand, komt aanloopen, vereenigt en dan zamen met verbazende snelheid in zee stroomen, liet strand doorbrekende, zoodat we overgezet moesten worden, en om den snellen stroom een heel omwegje moesten maken, (we kunnen niet recht door de uitwatering, maar moeten het staartjen van den Tji Mantjak omvaren, en zoo met een bocht door de Tji Siih, weêr op strand komen). Bij het overvaren zien we den G. Batoe Poetri (laag, begroeid) voor ons over den Tji Siih heen. Menschen vau den K. Pangarangan (4 paal van den post) zetten ons over; 6 man moesten, tot aan den hals door het water wadende, de schuit, die gebosèhd ${ }^{2}$ werd, halverwege te gemoet komen om haar door den stroom heen, aan wal te brengeu. Na 5 minuten verder een baloengbang (zelf gevormde zijtak) van den Tji Siih, uu Tji Talanța geheeten, doorwaad te hebben (1 (?) voet water), waar vroeger de weg, recht langs strand, tot aan G. Batoe Poetri voortliep (die nu verlegd is moeten worden en binnen doorloopt) kwamen we aan den eersten post van Bajah, behoorende onder Pangarangan, aan de overzijde van den Tji Siih. Op ongeveer een paal afstands doorwaadt men den Tji Mandiri, breed maar ondiep; vervolgens den Tji Poenaga Rokoj, Tji Pabèasan, Tji Borètè, Tji Soerèn (tusschen welke laatsten woestmooije rotspartijen zijn); de overigens duinzandige weg loopt hier over rots, tusschenwelke-door de Tji Borètè zich met een naauwe sleuf den weg naar zee baant. Een schilderachtig gezicht was bij den doortocht van de bedding der Tji Poenaga Rokoj de zee links vlak-bij, schuimende over de klippen, en over den stroom niet hangende maar liggende, een 'reeks van donkere njamploengs, hun takken

1 Bekende, aan zee groeijende planten.

2 Ngabosèh, zooveel als het Mal. gajoeh, menggajoeh (roeijen). 
in het water en rotsblokken daaronder en tusschen door. De Tji Kiraj had meer water, en werd doorwaad, evenzoo de Tji Naranas, de (drooge) Tji Tahi-kebo, de Tji Dahoe, met een breede maar drooge kalk- en schelpbedding; de Tji Pangendogan; we gingen Tandjoeng Tjariang voorbij; daarop Tji Panjawoengan, Tji Tjang Kangkrang, Tji Kĕsal en Tji Bobòs (vlak langs zee, met stoute, woeste klippartijen); eindelijk, vlak bij den post, Tji Bedil, daarop steil klimmen op een helling van den G. Tji Hiara, even steil dalen, na van boven-af een prachtig gezicht op den, zich 100 voet dieper, voortzettenden weg gehad te hebben, met een rakit of gètèk (aan elkaâr bevestigde bamboes, met een sasak er over heen) den Tji Hara, (Hiara? M.) 25 à 30 voet hier diep, en toch onbevaarbaar, overstaken, (prachtig gezicht, de breede, heldere stroom rechts zich voortzettend tusschen donker groen, waaronder ook klappers, overblịfselen van een oude dèsa, nu verlaten). Aankomst te post Tji Hara. Eten djodjongkong ${ }^{1}$ en visch. Vervolgen onzen weg. 12 paal. We blijven onzen weg vervolgen, op kleineu afstand van de zee, door een meestal met laag kreupelhout, soms ook met hooge boomen, overschaduwd duinpad, zoo-te-zeggen effen en vlak. We doortrekken sukcessievelijk weêr een reeks van winterstroomen, meestal droog, soms-ook net 1, 2 voet water; den Tji Tjatang, Tji Tjantigi, Tji Moendoe, Tji Tjankroewang, Tji Djompong (wiens water, in de naauwelijks 3 voet breede bedding, schilderachtig over kolossale, met mos begroeide rotsteenen, onder donker loof half verborgen, van den noordkant komt aanbruisen, op kleinen afstand een schuimend, zilveren, liefelijk watervalletjen vormend, en links van den weg zich wêer schuimend en bruisend verliest in het witte duinzand, en op 1 minuut afstands opgenomen wordt door den Oceaan). Tji Poenaga, Tji Soeoeb, Tji Sedekan (waar-vlak-voorbij duin en duinpad en strand ons eensklaps verlaten, en we een halven cirkel van eenige oogenblikken moeten beschrijven over rotsbrokken en klippunten, nú droog, maar bij hooge zee stellig niet te passeren, zoodat b. v. de patih van Lebak er eens heeft moeten overnachteu, eu tegen wier wilde voortzetting in zee de woeste branding onophoudelijk maar machteloos kampt), Tji Poenaga Rojom, Tji Kanjèrè, Tji Karang hidĕng, Tji Sawĕg, Tji Kadjar Kadjar en Tji Panghèotan, 5 paal ruim van Tji Langkahan,

1 Dit woord is mij onopgehelderd gebleven. 
van waar af onze toch al doodsche en vrij eentoonige weg nu, tot-op $1 \frac{1}{4}$ paal afstands van Tji Langkahan, nu-weêr onophoudelijk langs het, hier harde vaste zandstrand, begrensd door pandan loopt, altijd rechtuit. Na den Tji Pager betrekkelijk een heel poosjen vlak langs ons strandpad gehad te hebben, steken we hem over (hij is vrij breed, doch we hebben maar door een half voet water te waden) en verlaten kort-daarna het strand, om, ons landwaarts in buigende op een vlot den breedeu, vischrijken en 25 à 30 voet diepen Tji Langkahan over te varen. We rijden een eindtjen tusschen groene alang-alang-velden, die een baar voor jonge tarwe zou aanzien, door, doch komen welhaast langs wuivende klappers met vruchten beladen, en waaronder vreedzame woningen verscholen liggen; trekken met overdekte houten bruggetjens de kleine, nu bijna-waterlooze Tji Rantja Toendjoeng (iets meer dan een $\frac{1}{2}$ ) en Tji Kangkang hoè (veel-minder dan $\frac{1}{4}$ paal van de hoofdplaats), en komen zoo, een hoek omslaande in de kom der gemeente, klein, maar lachend en vriendelijk, waar een recht, breed pad, aan weêrskanten belommerd met klapperboomen (van vorm ngarandakah (?)), wier takken onzen weg overschaduwen, ons, over den aloen-aloen, omplant met jonge, frissche tamarinde's, naar den, na den tot 5 uur geduurd hebbenden tocht, zeer welkomen pasanggrahan leidt.

14. Junij Om 7 uur weêr te paard om B. gezelschap te houden op een 4 paal verren tocht ter opneming en opmeting van een door het inlandsch bestuur ontworpen waterleiding, waarvan 100 baoe's nieuwe sawahs de schoone vrucht zouden zijn. De Demang zegt me onderweg, dat hier enkel aan menschen, volstrekt niet aan goeden grond voor het aanleggen van sawahs, gebrek is.

Op den terugweg van het Soesoekan 1 opnemen had ik van een legok, 2 rechts van den weg, het eilandtjen Tindjel zien liggen, met klappers beteeld, die aan inwoners van Tji Langkahan toebehooren en door hen geëxploiteerd worden. B. bv. kocht van menschen hier zijn olie. In den laatsten tijd schijnt er echter een ziekte of zoo onder de boomen te heerschen, die de heele teelt met vernietiging bedreigt. B. beịvert zich nu om den nieuwen demang de noodzakelijkheid te betoogen, dat de

1 Rigg: a canal, an artificial water-course.

2 Rigg: hollow, ... A deep narrow valley. 
uitgestrekte, frissche alang-alang vlakte, 'die van-uit den pasanggrahan te zien is, met klappers en vruchtboomen beplant worde; dit zal waarschijnlijk het volgende jaar gebeuren. Dan zal deze oude zetel van het Regentschap wel weêr wat van zijn vroegere bevolking en welvaart teruchkrịggen (over den breeden Tji Langkahan was, waar wij overvoeren, toen een brug). - Om 5 uur ben ik, al schrijvende aan dit journaal, getuige van de verkiezing van 2 djaro's of dorpshoofden, waarbij ik de vrijmoedigheid van den kleinen man bewonder, waarmeê hịj uit volle borst tot zijn hoofden spreekt; met verbazing opmerk, hoe een kampong haar rechten bij deze gelegenheid wil doen gelden op een stuk onontgonnen boschgrond, voór meer dan 25 jaren door een naburig dorp, zonder weêrspraak van die kampoeng, geokkupeerd en ontgonnen; en de kiezers van het eene dorp (de verkiezing van het andere dorpshoofd was niet doorgegaan, omdat de verkozene bepaaldelijk weigerde djaro te worden, zoolang de bovengenoemde kwestie over den, zijn kampoeng oorspronkelijk toebehoorenden, boschgrond niet was uitgemaakt) op de gewone plechtige wịjs (nl. op de knieën liggende, met het lichaam vooruitgestrekt, en, na het maken van een sembah, de tot dat einde vooruitgestrekte handen van hun nieuw hoofd even tusschen de hunne drukkende) één-voor-één de gebruikelijke hulde aan hun nieuw Hoofd zag brengen.

15 Junij. Vertrek van Tji Langkahan. Schaduwrijke weg, met hooge waroe's aan weêrskanten. Zachte up and down's, maar altijd toch rijzende; mooi, breed en zacht, enkel in het laatste gedeelte een paar minuten steenbrokken. Vlak-vóór den eersten post (Kandang Sapi) passeeren we met een overdekte brug de Tji Sangiang. Vlak-voorbij den post passeeren we tweemaal den Tji Giri Laja, noch een andere rivıer Tji Boeroeloek, tweemaal; daarop in langen tijd geen. Sterkere golvingen van den weg. De Tji Pataäp, breeder dan de beide vorigen, vlak-bij de Tji Boeroeloek noch eens. -3 paal van den $2^{n}$ post de Tji Pénděj, die we per overdekte brug overgaan, en waar ik rechts den Tji Kadoe zich door de diepte zie slingeren en verder niets dan eindeloos woud. Bij de Tji Pĕndĕj eenige sawahs, 5 minuten verder de Tji Kadoe over, met een brug; aan weêrszijde eeuige sawahs. Oeroet kebon pedes. ${ }^{1}$ Vervolgens gaan we den Tji Rantja (daarbij overblijfselen van een kampoeng), vrij breed en

1 Overblijfselen van pepertuinen? (M). 
waterrijk, over; den Tji Palaboe, beide met sasaks, en komen aan post Wasang Krama. Iets-minder dan 2 paal voorbij dien post neemt onze demang afscheid en begint het demangschap Parong Koetjang. De weg wordt nu een aaneenschakeling van steile, steenige up and downs. We gaan verscheiden riviertjes over, o. a. de Tji Liman, $2 \frac{1}{2}$ paal van den post, breed (redelijk-) met een overdekte 'brug; met (links) op korten afstand deн Pasir Kopo Kopo, begroeid met hooge boomen. Gedurig prachtig bosch en berggezichten, diepe dalen en glooijende berghellingen, welig begroeid, vooral rechts. Komen welhaast aan post Kadoe Batara, vervolgen na eenig oponthoud onze reis, bedreigd door regen, die weldra losharst, en ons drie palen lang op 't lijf valt, zoodat we druipnat te Goenoeng Kentjana aankomen. De weg is nu vol tjadas 1 en rotsstukken, met vrij-steile hellingen, en zeer glibberig.

We gaan onderscheiden riviertjens over. Op de laatste hoogte of rug zouden we een prachtig vergezicht over het noorder landschap gehad hebben, dat zich hier met zijn bergen en vlakten en dalen aan onze voeten ontvouwde; maar de regenlucht omnevelde en bedierf het. Aankomst, na 21 paal rịjdens.

Ik mak met kompagnies- en andere duiten kennis.

16 Juni. De weg nu een aanhoudende opeenvolging van lange hellingen, vreesselijk uitgespoeld en gedurig vol tjarlas. Op \pm 2 paal afstands van de pasanggrahan gekomen, verrijst (links van ons) de Poelo Sari, daar nevens de Karang, en voorts het eindelooze, vlakke eentoonig- dofgroene, halfgrijze noorderlandschap. Op bijna 3 paal afstands gekomen, passeeren we, rechts van ons den kampoeng Bodoer, bevallig op een groene heuvelhelling gelegen en geheel verscholen onder zijn klapperboomen en ander opgaand hout; tusschen de heuvelhelling en ons ontmoeten we weêr (o merkwaardigheid!) een 10tal baoes sawah, besproeid door water uit de Tji Kolè, die we daarop passeeren en welhaast te post Bodoer (enkel-post) komen. We vervolgen nu onzen weg een tijdlang over een zachten, zwarten, holklinkenden aardweg, meestal door waroe's beschaduwd, na alvorens vlak-na ons vertrek van den post eenmaal steil te zijn geklommen,

1 Tjadas is volgens een gevonden aanteekening tufsteen en er worden toe gerekend alle conglomerata, van den fijnsten zandsteen tot den grofsten puddingsteen, in het algemeen alle uit water afgezette steensoorten, bijgevolg kleilagen. (M.) 
en op den legok den Karang, den Poelosari en het geheele noorderlandschap aan onze voeten gezien te hebben. Tets meer dan een paal van den volgenden post (pos Polèng) begint het tanjakan Bodo, uit tjadas paèh ${ }^{1}$ bestaande, en de bezwaarlijkste daling verrewech, die ik noch gezien had. We moeten van onze paarden en langs tjadas-trappen die zeer steil zijn, een lang eind dalen. Eerst-vlak vóor de Tji Lajang, waar het tanjakan Bodo eindigt en tanjakan Polo begint, stijgen we weêr te paard. We doorwaden den Tji Lajang ( $\frac{1}{2}$ voet water), komen 2 minuten later aan den Tji Oedjoeng, dien we met een sasak parahoe (een sasak op praauwen, door menschen voortgeduwd) overgaan, om te ankeren op Post Polèng. We krijgen nu, na aanvankelijk een paar vrij-steile tjadashellingen te zijn overgegaan, een eind wegs zeer redelijken en belommerden weg, waarop, door het gedurig kronkelen de Poelosarı en de Karang, die zich verscheiden malen over het eindelooze bosch- en glagahlandschap henen, met de noorderkuststreek aan ons oog vertoonen, nu-eens rechts, dan eens links van ons, dan-weêr achter ons liggen. Het la atste gedeelte van den weg, waar hij over den Pasir-Angin loopt, is verschrikkelijk. Het gaat al dalende, eerst over blaauwe steenklompen, later langs glibberigen, brokkeligen tjadlas, langs een zeker 100 voet diep ravijn naar-omlaag, naar den Tji Simět. B. gaat in een tandoe; allen stijgen van hun paarden; alleen-ik, gesteund door mijn uitmuntend paard en bemerkende, dat ook de twee voorrijdende dorpshoofden niet afstijgen, blịf te-paard tot-aan de laatste helling, al-te steil en glibberig om zonder gevaar, (hoewel het mijns inziens kan) te-paard te blijven; een helling die men in eene minuut afgaat, doorwaad daarop, wederom te-paard, de hier breede en vrij-diepe (soms was het achterste gedeelte van mijn paard geheel onder water) Tji Simět, dien ik dwars moest doorgaan om den sterken stroom te ontwijken, en kom in de ruime woning van den demang van Lebak.... $\mathrm{Na}$ het diné heb ik een voorloopige ontmoeting met vier hoofden van de Badoewis; den Girang pohon, den kokolot, en den Girang serat, benevens den djaro van hun dorp Kanèkès. Het zijn forschgebouwde menschen, met geheel-andere gelaatstrekken dan de Soendaneezen; veel geelbleeker ook van kleur; zeer bescheiden maar zonder in het-minst verlegen te zijn. Op onze vragen gaf altijd de Girang pohon het antwoord. Hij zeide, dat ze drie

\footnotetext{
1 Paih bij R., dead; hier onvruchtbaar? (M).
} 
dorpen bewonen, Kanèkès, Tjibéo en Rawajan; dat in een dorp niet-meer dan 40 koerènan (een man met zijn vrouw, een gezin) mogen wonen; dat ze besnedẹn worden (disoenatan); dat ze een eigen letterschrift hebben, waarmeê ze op bamboe griffelen (hij gaf daarvan een proeve door met onverklaarbare streepjes zijn naam Jasma te schrijven), dat het leeren van Arabisch letterschrift boejoet (door de godsdienst verboden) is; evenzoo het aanleggen van sawahs (ze hebben enkel hoema's), het dragen van goloks, het planten van andere gewassen dan dangder, 1 rijst en pisang..... Na het vertrek van de Badoeï's worden we vergast op een muziekgezelschap uit Karang, bestaande uit twee zingende jongens, geakkompanjeerd van een tarawangsa en een soeling, wel melodieus en het meest Europeesch klinkende, dat ik noch van inlandsche muziek gehoord heb. Wandeling door Lěbak of liever Kĕsang, waar de Demangswoning ligt. Lěbak is aan de overzijde der rivier, (op een kleinen afstand). Lěbak (om hier het woord in den ruimsten zin te nemen, dat het èn Lěbak èn Kĕsang omvat), draagt zijn naam met eere, want het is in een diepe, kleine dalkom (men zou hem, dunkt me, in een half uur kunnen rondloopen), eingeklammert tusschen den pasir Angin, pasir Salem (links, als men van G. Kentjana komt), pasir Ipis, (rechts, idem), en pasir Lamè, waar morgen onze weg naar Rangkas Betoeng over leidt. Reeds bij het afdalen der laatste hoogte van den pasir Angin was het gezicht op die sterk bewoonde dalkom, bijna van alle kanten door de breede wateren van de Tji Simět, die zich hier als een slang heen en weêr kronkelt, en zelfs een paar eilandtjens vormt, en met een grasrijke weide, vol grazende buffels, een verrukkelijk gezicht, en bij onze rondwandeling werd de eerste indruk bevestigd, hoewel we ons verbaasden over de massa noch onbenutten grond, waar men althans, dunkt me, klappers zou kunnen planten.

Ik vergat noch-twee dingen: 1. Het kostuum der Badoeï's. Eiffen-donkerblaauw, indigokleur. De girang pohon had een doek van grof wit, de girang serat een van grof-geel katoen om 't hoofd geknoopt, de beide anderen een donkerblaauwe. Enkel de djaro had een kris. - 2. Ik vond hier een gedrukt exemplaar vau 's pangoeloe's Tjarita Ibrahim, maar vernam, dat ook-hier buiten den demang niemand het Jav. letterschrift kent.

1 Rigg: Janipha Manihot

3e Volgr. IV.

\section{Kassave.}

22

22023 09:51:12AM

via free access 
17 Juni. Vroeg op reis, passeeren, na ruim een paal steil klimmen en dalen, met een sasak de Tji Simět. Aan weêrskanten een K. Lěwih Damar. Passeeren een reeks van vruchtbare dalen, door de Tji Simĕt bespoeld, met prachtige buffelkudden en vrij-wat sawahs. Vooral de dalvlakte, waar de welvarende dessa Tjilaki in ligt, uitgestrekt en lachend. De Tji Simĕt slingert zich met een oneindig getal kronkelingen rechts van onzen weg voort, een aantal eilandtjens vormende en door zijn afgescheurde kanten zi.jn kwaadaardig karakter toonende. - $\mathrm{Al}$ verliezen we hem nu en dan een poosjen uit het oog, de uitstekende kruinen der kokospalmen in de verte wijzen van zelf aan, waar hij langs loopt. De weg-zelf loopt meestal tusschen glagah en kreupelhout door, en tot de afdeeling Waroeng Goenoeng toe (3 paal van de hoofdplaats) komen we maar zelden door dorpen (ik herinner me enkel Dago, daar-vlak-bij Wanti, en een derde, waarvan de naam me ontschoten is.) De weg-zelf, hoewel beter en gemakkelijker dan we sints Tjilangkahan er een gehad hebben, loopt toch tot aan de grens van het Rangkas-Betoengsche over zeer geakcidenteerd terrein, van tijj tot tijd uit gemeenen tjadas bestaande, Het aanleggen van dien breeden weg, die NB. toch voor geen rijtuig begaanbaar is, door de up and downs, moet ontzettend veel arbeid gekost hebben; we kwamen o. a. door een uitgraving (water om te "spoelen" is hier niet), waar men zeker vijf voet tjadas heeft moeten wegwerken. De namen van allerlei winterstroompjens die we overtrokken, ben ik gelukkig vergeten. Aan de grens der afdeeling Waroeng Goenoeng, $3 \frac{1}{2}$ paal van de hoofdplaats, wachtte ons de demang, een flink, aangenaam man. Allerwege op onzen verderen weg ontmoetten we nu teekenen van toenemende welvaart en bevolking. Na de Tji Simět, hier breed en diep, aan het veer met eeu èrèlan te zijn overgezet, bevonden we ons onmiddelijk in de hoofdplaats, een lange reeks van onder het groen verscholen, wijd uiteengebouwde woningen, links van den weg (rechts-noch tegal, en hier en daar uitgestrekten aanplant van oneetbare pisang.) $\mathrm{Na}$ een klein kwartier rijdens kwamen we op den keurig-onderhouden, frisch groenen aloen-aloen, dien we schuins opdraaiden, ten-einde zoo, langs den weg die van den dalem naar het, recht daartegenover liggende en van hier zichtbare fort voert, aan de verwelooze, maar ruime en smaakvol gemeubeleerde woning van B. te komen, waar we kwartier voor twaalven afstappen. 
23 Juni. 's Morgens vergadering, ten huize van B., met inlandsche hoofden, ten-einde hen te konzulteeren over het Waroenggoenoengsche dialekt. Een demang, die een erge pratevâar is, maar wiens autwoorden ongelukkig nooit slaan op de hem gedane vragen; de eenvoudigste dingen op dit gebied (anders is hij niet dom) moest men hem driemaal herhalen, eêr hij de portée van de vraag begrijpt. Een gepensioneerd onderkollekteur, die geen mond opendoet. Een "panghoeloe landraad" met een energiek, maar fanatiek gezicht, die eveneens stommetjespeelt. Een "panghoeloe distrikt" endelijk, wiens bewegelijke oogen tintelen van intelligentie, en die zich van-tijd-tot-tijd permitteert de verkeerde opgaven van den demang te verbeteren. Het resultaat van de zitting is luttel, het werken met zulke menschen een wanhopig iets. $\mathrm{Tk}$ ben dankbaar, dat de aankomst van de post me om elf uur aanleiding geeft tot het wechsturen van de stoethaspels. Tk verbaas en erger me op nieuw over de minachting, waarmeê deze Soendaneezen over hun taal en hum letterschrift spreken (welk laatste hier niemand, zelfs de demang niet kent). Van Soendaneesche tembangs geen spoor te ontdekken. De Tjarila Ibrahim van den Garoetschen-hoofdpangoeloe (om dit feit hier pro memorie te noteren) vond ik te Lěbak in handen van den djoeroe-toelis en de djaro's, maar toen ik vroeg of er iemand was die hem !ezen kon, was het antwoord: "niemand dan de afwezige demang." De Muzelmansche vroomheid hier overigens, evenals overal waar ik tot-nu-toe kwam in het Bantamsche, zeer groot. Het wemelt van hadji's, van kleine bidplaatsen in de kampoengs en de mesigit (die men in elke kaloeharan, wij zouden zeggen: in elke gemeente, aantreft) wordt druk bezocht. Ronggèngs, die pest voor de bevolking, worden hier niet geduld; enkel om de noord, in het Sèrangsche, heeft Javaansche invloed ze gebracht.

....... het fortjen, dat, hoewel vóór vijf jaar nieuw opgebouwd, in beginsel een antikwiteit is. Andere tijden, andere zeden. Wat misschien noodig was, toen de kommurikatiemiddelen zooveelgebrekkiger waren, en het Europeesch gezach zich in deze streken oneindig-minder rechtstreeks gelden deed, zoowel ter handhaving van de rust, als ten voordeele van de door hare hoofden geknevelde bevolking, schijnt me nu tamelijk overbodig. Maar het gaat Bantam (de éénige residentie op Java, waar men op de hoofdplaats van elke afdeeling zoo'n fortjen vindt), gelijk het spreekwoord zegt: "wee den wolf, die in een kwaad gerucht 
staat." Ten overvloede is het fortjen door geen gracht, maar enkel door een aanplant van aloé (waaromtrent geregeld gerapporteerd en geïnspecteerd wordt!) gedekt, zijn de blindeeringen der ramen door hun zwaarte bijna-niet tilbaar; en is geen enkel stuk geschut in het fort anwezig. De bouw kost $f 100,000$. Maar voor waterleidingen, ten-einde de bevolling nieuwe sawahs zou kunnen aanleggen, heeft de Regeering Lěbak noch nooit één cent te goed-gedaan, in weêrwil zij er jaarlijks aan landrente $f 80,000$ uittrekt, en die uitgaaf spoedig een zeer produktieve zou blijken te zijn.

24. Junij.... 'k Vind op B's kantoor een stapel Soendaneesche boeken, waaromtrent B. me meêdeelt dat ze hier onverkoopbaar zijn. Datzelfde had ook de heer H. me reeds meêgedeeld, met bijvoeging dat er in het zoutpakhuis stapels lagen.

27 Juni. Oın half zeven ga ik met mijn gewoon eergeleide op weg. De weg is, tot een eind vóór post Gentèng, mooi, vlak en effen, zoodat we bijna altijd in gestrekten draf rijden, ınaar leidt door een waterlooze en bijna onbevolkte streek, waar niets groeit dan wat houtige struiken, kreupelhout en een enkel groepjen opgaande boomen hier-en-daar. We komen hier niets voorbij dan ( $1 \frac{1}{2}$ paal van Rangkas Bitoeng) den Tji Djoro paèh (dien we per brug overgaan); den kampong Tji Dadap, een eindtjen ter zijde van den weg; de Gardoe Tji Kapas (3 paal) en de Gardoe Tjampaka ( 6 paal). Even als tusschen Tjilangkahan en Rangkas Bitoeng, ook hier-weêr op last van den Rezident, aanplant van vruchtboomen langs den weg, die totaal mislukt is, omdat na het planten er niemand meer naar omgezien heeft. Dicht bij post Gentèng, misschien $1 \frac{1}{2}$ paal er van daan, zien we, op een verheffing van den weg, eensklaps een prachtig panorama zich voor onze oogen ontrollen. Ver-links, bijna op zijde van ons, de Goenoeng Doelang; eveneens links van ons, maar een eind rechts van den Doelang, de G. Djasinga; vlak vóor ons uit de G. Endoed met zijne twee toppen en de G. Boetak; vèr rechts de, schijnbaar althans, lage heuvelenrijen, waar tusschen Lěbak besloten ligt. Lachend en vriendelijk is het gezicht van de kampoeng Gentèng, rechts vóor ons uit, in een vallei liggende, aan den Tji Bèrang, omringd door groene heuvels. Nadat we deze wechverheffing zijn afgedaald, wordt de weg, hier over den G. Gentèng loehoer loopende, ongelijk en moeịjelijk; heele einden bestaan uit tjadas, de up and downs zijn vele en steil: en zoo blijft het, tot we na den 
Tji Bihoek, een riviertjen dat in den Tji Bèrang uitwatert, te zijn overgegaan, den post Gentèng bereiken, die een half uur van den kampoeng Gentèng verwijderd ligt.

De weg blijft van hier tot Sadjera toe onophoudelijk over een, nu meer dan minder, golvend terrein loopen, maar de landstreek wordt vriendelijker en volkrijker. Even-nadat we van den post vertrokken zijn, passeeren we den links van ons, een paar minuten van den weg liggenden, kampoeng Tji Loewak, behoorende tot het distrikt Sepang; er woont een mantri tjatjar. ' $\mathrm{Na}$ een groote paal te hebben afgelegd, dalen we ongemerktglooijend af naar de breede, maar wederom ondiepe Tji Bèrang, wier wateren ons verkwikkend tegenruischen, terwijl aan de overzijde, een weinich rechts van het punt waar we ons bevinden, de huizen en klapperboomen van den kampoeng Bolang het landschap alleraangenaamst stoffeeren. Met een kleine kromming van den weg links-om, komen we, na vijf minuten langs de rivier te zijn voortgereden, aan het punt waar we haar met een èrètan (een vlot, dat met een touw wordt overgetrokken) oversteken moeten. Vlak-bij dat punt kronkelt zich, links langs den weg, de smalle, bijna-waterlooze, maar onder het hoog geboomte, waarmeê de pasir Djanggot begroeid is, schilderachtig verscholen Tji Djanggot. Aan den overkant van de Tji Bèrang wordt het landschap steeds waterrijker en bevolkter. Vlak-bij den stroom noch, passeeren we, links van ons, den kampoeng Soesoekan; gaan daarop de kleine Tji Djadjawaj over; en komen vervolgens den, door den Tji Mèntèng in twee deelen gescheiden, grooten en welvarenden kampoeng Karian door, van-waar-uit het gezellig geluid van het rijststampen ons tegenklinkt. $2 \frac{1}{2}$ paal van Sadjera gekomen, gaan we de kleine, vlak bij elkaâr liggende, Tji Tjahoer en Bajoe-poetih over. Op $1_{2}^{1}$ paal van Sadjera leidt onzé weg ous door prachtige sawahs, toebehoorende aan de kampoeng's Bondol (links van ons, aan den zoom van die sawahs tusschen zijn klapperboomen zichtbaar) en Somang. We passeeren de gardoe Tjarèktjèk; dalen, even voorbij die gardoe, naar de Tji Lèwoh af; en komen, na het stroompjen te zijn overgegaan, op nieuw langs prachtige sawahs, behoorende bij den kampoeng Sawah (dien we welhaast, in het voorbijgaan, links van ons, aan den zoom van den weg, zien liggen.)

\footnotetext{
1 Vaccinateur. (M.)
} 
..... Doch revenons à nos moutons, of liever: laat ons den tocht naar Sadjera voortzetten. We hebben niets meer te doen dan de Tji Bitoeng over-te-gaan, en een weinich rijzende, bevinden we ons eensklaps bimnen de kademangan (distriktshoofdplaats), eene kleine, landelijke plaats, aan den westkant van de Tji Bèrang.

30 Juni. Nieuwe konferentie met de inlandsche hoofden, van achten tot elven. Tk begin, met groot suceès voor het doel mijner reis, hun de Woelang Poelra voor-te-lezen, en daaraan allerlei vragen vast-te-knoopen, ze luisteren als vinken. Om elf uur moet ik uitscheiden, daar het kiezersvolk van onderscheidene dorpen reeds-lang zit te wachten, om (behoudens goedkeuring van den kontroleur) in onze pandopo zich nieuwe djaro's of dorpshoofden te kiezen. Het is een kurieus iets, zoo'n verkiezing. De aftredende djaro zit vóór het kiezersvolk, en op de éérste rij van dit laatste zit, door zijne nettere kleeding ouderscheiden, degene die de kandidaat van het kiezersvolk is. De demang speelt voor tolk, staat uit naam van den kontroleur het verzoek van den ouden djaro om ontslach toe, en noodigt de heeren kiezers, "jongen en ouden", uit om zelfstandig en ieder naar eigen, vrije overtuiging een nieuw hoofd te kiezen. Daarop neemt een van die heeren, gewoonlijk de buurman van den kandidaat, het woord, om (vingerwijzend op het individu) diens naam te noemen. Vraag van den demang, of jemand een andere kandidaat heeft. Algemeen, en onveranderlijk-e en p a rig gemompel van: "Met uw verlof, geen ander." (soemoehoen, lĕ aja $\left(\boldsymbol{C}^{\prime} i\right)$, onder even-eenparig brengen van de saamgevouwen handen naar het voorhoofd. Soms moet nu de kandidaat op een apart plekjen, meer vooruit of op zijde, gaan zitten (soms laat men die formaliteit na), en worden de heeren, die zijn kandidatuur ondersteunen, uitgenoodigd om queue achter hem te vormen. Algemeene overlooperij natuurlijk; het kiezersvolk is hier een even zelfstandig ras als in Nederland. Daarop proklamatie van den nieuw verkozene, door intermediair wederom van den demang. Vervolgens een stereotype (men zou zeggen ernstig-gemeende, als we niet wisten dat bij voorkeur de Pecksniffs met een ernstig gezicht hun infame leugens zeggen) aanmaning aan de kiezers om de bevelen van den nieuwen chef gehoorzaam op te volgen, en aan deze laatste, om bij de uitoefening van zijn gezach recht en billijkheid tegenover zijn onderhoorigen stipt te betrachten. En nu hiermeê is de vertooning afgeloopen. Is het een doode vorm, geheel zonder wezen? Ik weet het niet. 
's Middags van vieren tot zessen zette ik mijn lektuur van de Wuelang Poetra met de hoofden voort.

1 Juli. 's Ochtends van achten tot twaalven voortzetting der lezing met de hoofden van de Woelang Poetra. 's Middags van vieren tot zessen op nieuw. Daarna een wandeling door de, alle blijken van welvaart dragende kampoeng (die volgens opgaaf van den demang 115 heerendienst-plichtigen, Orang Koewal, 900 zielen, telt.)....

2 Julij. 's Ochtends breng ik van zevenen tot twaalven wederom met de inlandsche hoofden door, en voleindig met hen de lezing van de Woelang Poetra.... Om half drie gaan we gezamenlijk naar de rivier (de Tji Bèrang) om naar een bizondere manier vau vischvangen te kijken. In het midden van de rivier liggen, tot een lijn aaneengebonden, drie praauwtjens, waarboven vischnetten ter hoogte van drie voet uitsteken. Van de beide uiteinden der praauweurij naar de beide oevers loopen schakels, die het voorbijzwemmen van de visschen beletten. Nu wordt de visch door meuschen, die op zekeren afstand de rivier ingaan, en zich langsaam in de richting der praauwen voortbewegen, met groote steenen opgejaagd; aan de praauwenrij gekomen, en niet verder voortkumnende, springt hij in zijn doodsangst boven het water uit, stuit tegen de uitstekende netten, en valt in de praauwen. Gelijktijdig zijn sommige van de opjagers bezig, om vlak-nabij de praauwen naar den visch te duiken, ten einde dien met de hand te grijpen. Ter onzer eer leenden zich, zooals ik naderhand hoorde (aan de nakende lichamen, zooals de demang terecht opmerkte, was het niet te zien) voor dat opjagen en duiken ditmaal bij-uitsluiting hoofden.

3 Juli. Om half-zeven op de gewone wijs van Sadjera naar Lěbak. Het landschap en de weg verschillen weimich-of-niet van hetgeen ik tot heden zag. Het terrein heuvelachtig, vol up and downs; bijna-uitsluitend begroeid met galagah en laag kreupelhout; weinich-bevolkt; en bezaaid met lichtgeelen wadas, ' die aan den (weêr zeer dom aangelegden) weg gedurig een zeer unheimisches aanzien en in den regentijd, dunkt me, een alleronpleizierig karakter geeft. Na bijua-drie paal gereden te hebben, gingen we de Tji Latoek over, die in de Tji Laki uitwatert; passeerden, een paal verder, den zijweg (rechts van ons), die

$1 \mathrm{Ml}=$ tiadas. 
naar den kampoeng Maraja leidt; gingen vervolgens de, vlak bij elkaâr liggende, Tji Tjangkohkor en Tji Malèger over, beide zeer klein: passeerden sawah tarlah, ${ }^{1}$ aan de bevolking van Maraja behoorende; gingen, na ongeveer $4 \frac{1}{2}$ paal gereden te hebben, de Tji Tjangkor over; passeerden, even verder, den K Tjoemenggèr (rechts van ons), en kwamen welhaast (иа, meen ik, noch een K. Tji Bërih met mooije sawah tarlah te zijn voorbijgereden) aan den eersten post, Tji Laki geheeten, eu 5 paal van Sadjera liggende. Vlak-voorbij dien post wachtte ous het overgaan van de smalle $\mathrm{Tji}$ Waroe, het passeeren van den K. Tji Laki, en de doorwading van den, vrij-waterrijken en redelijk-breeden Tji Laki, de grensscheiding van de afdeelingen Sadjera en Lěbak. Even-voorbij paal 50 (van Sĕrang wel-teverstaan) gingen we de kleine Tji Djamboek over, passeerden den gardoe en pasar van Tji Minjak (de kampoeng zelf van dien naam was op een kleiuen afstand, links van ons in liet verschiet zichtbaar) en doorwaadden, eerst den lang-niet-oubeduidenden Tji Minjak, onmiddelijk daarna den kleinen Tji Nambo, waarna ons pad een eind aan weêrskanten omzoomd werd door sawal ladah. De demang van Sadjera en zijn gevolg had ons tot aau de grens van zijn afdeeling uitgeleide gedaun, hoewel die van Lĕbak ons reeds onder den post Tji Laki, dus op Sadjeraasch terrein, had opgewacht, ten-einde niet in de barre zon te moeten wachten. Al voortrijdende, passeerden we, even-vóor paal 51, K. Moentjang (rechts van ous) en kwamen welhaast in een uitgestrekt en lommerrijk bosch met prachtig opgaand geboomte, waaruit nu-en-dan het liefelijk gefluit van eeu zangvogel ons tegenklonk. Het is naauwelijks te gelooven, hoe'n weldadigen, verkwikkenden en verfrisschenden indruk zoo'n Urwald, met zijn aangename koelte, zijn tooverachtige lichteffecten, zijn krachtige vegetatie, zijn zachtsuizend gebladerte, op het, door de woestheid en naktheid van het eenvormige landschap neêrgedrukt, gemoed vau den reiziger maakt. Jammer maar, dat ons genot niet-langer dan hoogstens een paal duurde. $\mathrm{Na}$ de gardoe Lěwĕng podol gepasseerd te zijn, inochten we op nieuw tusschen eindelooze galagah doorrijden, hetgeen voortduurde tot-aan den tweeden post, Hantap geheeten, toe. We

1 Saroah tadah, Jav. ( welke hun water alleen van den regen, niet uit een stroom, ontrangen. (M.) 
haddeu nu 10 paal, twee derde van het traject afgelegd. Het derde en laatste gedeelte van den tocht liep door een totaal onbevolkte streek. We passeerden enkel de gardoe Hantap (een heel eind verder dan de post van dien naam), de gardoe Tji Lěsoeng, gingen, even vóor paal 58, den kleinen Tji Děngdĕng en den noch-kleineren Tji Tawa over, en kwamen spoedig daarop in de ruime, koele pasanggrahan te Lěbak of liever te Kĕsang (Lěbak ligt aan de ove rzijde van den Tji Simět; de woning van den demang en de pasanggrahan zịjn te Kĕsang), waar de gastvrijheid en goede smaak van den demang ons een uitmuntende ontfangst bereid had.

4. Juli. Den heelen ochtend, van zevenen tot twaalven besteed ik met mijn schrijver en eenige inlanders, aan het nagaan en noteeren van de hier gebruikelijke benamingen voor de verschillende ouderdeelen van een inlandsche woning. 's Avonds na den eten komen de demang en al de inlandsche hoofden nit deze afdeeling, met wie ik, bij gebrek van iets beters (mijn Soendaneesche volksboeken waren bij vergissing te Rangkas Bitoeng achtergebleven) het eerste gedeelte van den vuilen Si Miskin lees.

5 Juli. Aanvang van den tocht naar de Badoeï's. We gaan de Tji Simĕt over, in wier bedding, ten onze behoeve, tot aan het punt, waar eenige meerdere diepte begint, een geregeld voetpad van keijen is aangelegd, opdat we onze voeten niet zouden nat-te-maken hebben. Aan den overkant vau de rivier gekomen, zie ik bevestigd, wat ik reeds van-verre gemeend had op-te-merken, dat de bijua loodrechte afhelling van den weg naar de rivier, die het zelfs mij, toen we indertijd van Goenoeng Kentjana naar Lěbak kwamen, onmogelijk maakte, om op mijn paard te blijven zitten, nu uitgekapt (het terrein bestaat uit weeken ljarlas) en glooijend gemaakt is. We verbazen ons wel, dat niet veel liever een rigzag is aangelegd, hetgeen een oneindigradikaler verbetering zou geweest zijn; maar zijn al blijde, dat we oumiddelijk te paard kumnen stijgen, en vervolgen langs dit allerfataalste tjadaspad, steeds klimmende en dalende, hotsende en glidserend, twee palen ver, tot aan de gardoe Tji Boengoer onzen weg. Daar gekomen, verlaten we den grooten weg van Lěbak over Goenoeng Kentjana naar Tjilangkahan, en slaan een links, dus oostelijk, liggend voetpad in, dat naar Bodjong Mèntèng leidt. We doorwaden tweemaal de smalle Tji Manoek; éene maal op een punt, waar ze, vlak-bij ons, aan onze rechterhand, een klein, maar liefelijk, aangenaam-ruischend 
watervalletjen volgt. We passeeren de, rechts van ous, vlak aan den weg liggende, maar door de hooge alang-alang onzicht. bare, grot Karang pangantèn, volgens de legende zoo-genoemd naar een jong getrouwd paar, waarvan de man bij eene afdaling in deze grot om naar vogelnesten te zoeken zijn dood gevonden, en de vrouw toen uit verdriet zijn treurig voorbeeld opzettelijk nagevolgd zou hebben. Geen wonder, dat nooit een inlander noch den moed gehad heeft (gelijk de demang er bij vertelde), om zich in de diepte nêer-te-laten. We doorwaden den smallen Tji Dangdĕr, nadat we vooraf het voetpad, dat naar Bodjong Mèntèng leidt, verlaten, en op nieuw een, rechts, dus ongeveerzuidelijk, liggend'zijpad zijn ingeslagen; doorrijden een prachtig, boschrijk, met een dikke laag plantaarde bedekt, en (zoo er maar menschen woonden) voor de koffikultuur onbetwistbaar uitstekend-geschikt, landschap, waar een groep graven, schil. derachtig onder hoog geboomte half-verborgen, het vroegere aanwezen van een dessa noch verraadt; en komen nu zoo ain de Tji Boeniang, de grensscheiding van de afdeelingen Lebak en Paroeng Koedjang, dien we doorwaden, ten-einde over ParoengKoedjangsch grondgebied een eindweegs onze reis te vervolgen. Met steile dalingen, maar altijd over zwarten humusgrond, bereiken we welhaast de kleine, maar lachende, hoogvlakte van Parakan Běsi, op welks prachtige rijstvelden en ruime, nette woningen, die beide sprekende bewijzen der nabijheid wederom van menschen, we reeds onder het dalen geheel-onverwacht, en daardoor met dubbel genot ons oog mochten laten rusten. Parakan Bĕsi, dat geheel-afgezouderd ligt (want de gewone weg naar de woouplaatsen der Badoeï's loopt over Bodjong Mèntèng), is een groot, welvarend dorp. Met uitzondering van den rezident Buyn, was er noch-nooit een Europesan geweest. Voor een landschapschilder zou, dunkt me, een bezoek van dit liefelijke plekjen goud waard zijn. Aan de boording van den zacht kabbelenden, waterrijken, Tji Oedjoeng komt het, met zijn fraaije rijstvelden en wuivende kokospalmen en levendig gejoel van menschen en huisdieren, tegen de beklemmende eenzaamheid der wouden, die de omringende bergruggēn bedekken, zoo ongeloofelijk-vreedsaam en bevredigend uit. Althans dit was de indruk dien wij ontfingen. We waagden ons niet aan het overgaan van het smalle bamboezen brugjen, dat, hoog boven de rivier nit, blijkbaar ten dienste der bewoners, over het water gespannen, en met zijn beide uiteinden (zeer praktiesch!) op twee, over 
den stroom horizontaal zich welvende, waroeboomen bevestigd is; we maakten gebruik van het, blijkens zijn groene kleur nieuwe, voor de hooge gasten opzettelijk-vervaardigde, bamboevlot, dat gereed lag om ons den Tji Oedjong over, en in Parakan Bĕsi te brengen.......

De weg liep voortdurend door een prachtige bosch-stroek, berg-op berg-af. Eenmaal zagen we, rechts van ons, aan den snmiddelijken zoom van ons pad, een steil en diep ravijn, waardoor meneer de Bordes stellig, zoodra hij het maar zag, een spoorweg zou aanleggen, want het was geen "woeste wildernis", maar met gras en geboomte weelderig-begroeid. Een-andermaal kwamen we op een punt, waar zich (links) een trotsch berggezicht voor ons opende, doordien we heuvel aan heuvel en bergtop aan bergtop met scherp-uitkomende grenslijnen of omtrekken zich aan elkaâr zagen schakelen, in de grilligste vormen, tot in een eindeloos-vèr verschiet. $\mathrm{Na}$ lange en sterke dalingen, langs het, door gevallen regen slibberig kleipad, en het doorwaden van de kleine Tji Sèkè, kwamen we aan het kleine plateau van Tji Awi, waar een deputatie van de Badoeî's ons wachtte. Het waren de door het Goevermement aangestelde Djaro, een echte Badoei, Tarpi geheeten en wonende te Tjibéo, benevens diens eigen gekozen plaatsvervanger, den kokolot Tajoen, een van de uitgestootenen, wonende te Tji Barani, een ampihan of onderhoorigheid van Tji Samodor. De ongemeen-kloeke, breed- en forschgebouwde gestalte der beide mannen, hun blanke huid, hun edel, fraaibesneden gelaatstype, hun open, rustig oog frappeerde ons-beiden zeer. De djaro, een oud man met sneeuwwitte haren stak ons dadelijk trouwhartig, maar zonder de minste aanmatiging, zijn groote hand toe. In een opgeslagen loodsje dronk ik een klapper, terwijl B. eenige inwoners van den naburigen kampoeng Kebon tjaoe in het verhoor nam over de onwettige handhaving van een afgezet dorpshoofd door den demang van Paroeng-koedjang. We moesten nu, na een rid van 20 paal, afscheid nemen van onze paarden; want zoodra we den kampoeng Tji Awi verlaten en het tamelijk breede en waterrijke riviertjen van dien naam doorwaad zouden hebben, zouden we ons bevinden op het grondgebied der Badoë's, en daar worden door de godsdienstige overlevering, in treffende overeenstemming met de terreingesteldheid, geen paarden geduld. Weldra stelde de optocht zich in beweging. Ik zeg: de optocht, want de tegenwoordigheid van al de djaro's of dorpshoofden (door den demang, minder voor hun pleizier 
dan te zịnner-eigener eere meêgenomen, geloof ik) en de sleep koeli's die onvermijdelijk-noodig was om bultzakken en duizend andere dingen te kunuen overbrengen, maakte van zelf ons gezelschap tot een zeer lange trein. Aan de overzijde van de Tji Awi kwamen we tegelijk weêr van Paroeng-koedjangsch op Lebaksch grondgebied. Ik had mijn kousen en schoenen uitgetrokken, en me met een stok gewapend; daardoor viel het loopen over het voortdurend-rijzend terrein, en het doorwaden, eerst van de $\mathrm{Tji}$ Awi, daarna van de Tji Barani, vervolgens (driemaal) van de zich in allerlei bochten heêu-en-weêr kronkelende Tji Bogoh, en eindelijk van de breede, kristalheldere Tji Oedjoeng, me zeer gemakkelijk. Het smalle pad was op vele plaatsen uiterst-steil en uiterst-glibberig; maar we hadden bijna voortdurend schaduw hetzij van hooge galagah of hoog geboomte, en daarbij, door de hooge bergstreek waar we ons bevonden, een koele, verkwikkelijke temperatuur. Dit hielp. Daarbij de wandeling duurde niet lang. Na hoogstens-drie paal te hebben afgelegd, waren we aan den Tji Oedjoeng, en dezen doorwaad hebbende, in den op een heuvelrug aan diens oever liggende $\mathrm{K}$. Tji Samodor, het doelwit onzer reize.

Bij de beschrijving van dezen kampoeng vallen sommige dingen op te-merken, die tegelijk van de beide andere kampoengs der Badoeï's, Kartawana en Tjibéo gelden. Zoo ziju de huizen allen even-groot en moete n dat zijn. Ze zijn gedekt net daven kiraj, 1 een zeer stevige dakdekking die het minstens-drie jaar uithoudt (zeven jaar na den aanplant kan men de bladen voor-het-eerst oogsten; op vruchten moet men poeloehan, welasan, ${ }^{2}$ ja soms tot 20 jaar, wachten; de vruchten anoe bĕněr, diala tjangkokna, ${ }^{3}$ en worden eveneens behandeld als kitri djambé; ${ }^{4}$ de ljangkok ${ }^{5}$ en de boom beiden worden bij voorkeur in ranlja's, d. w. z. in drassigen grond geplant); alle àndere dakbedekking is boejoet, d. w. z. door de godsdienstige overlevering verboden, atap van alang-alang, atap van sè̀l, ${ }^{6}$ ja zelfs (behalve voor dekking van den nok) atap van injoek, den hier in-het-wild-groeijenden arènpalm. Het huis van

1 Bladen van de sagopalm (M.)

2 Tien of elf en daarboven. (M.)

3 Die goed zijn, daar worden de poters van genomen. (M.)

4 Pinangboomen?

5 Afleggers of poters. Zie Rigg.

${ }^{6}$ Een soort rotan. 
den girang poeöen (het, voor zijn leven uit een bepaalde familie door de dorpelingen gekozen plaatselijk hoofd, tenzij zijn vrouw sterft, als wanneer hij onmiddelijk voor een ander moet plaats maken, omdat hij niet voor de tweede maal trouwen mag, en een ougetrouwd man geen girang poeöen mag zijn) staat aan het zuidelijk uiteinde van den kampoeng, met de deuropening naar het noorden gekeerd. Daar-tegenover, met zijn frout naar dat van 's girang-poeöen's woning, dus naar het zuiden, gekeerd, staat de zoogenaamde balè, een gebouw, bestemd oin hun oogstfeest, de kawaloe (waarover later), in te vieren en gasten in te ontfangen (waar B. en ik dan-ook, zoo wel te Tji Samodor als te Tjibèo, met onze jongens werden ingekwartierd). De overige woningen (waarvan er te Tji Samodor enkelen ook-noch be n o o r den de balè stonden) zijn allen volgens een zelfde model, op houten stijlen hoog boven den grond, en dicht aan elkaâr gebouwd, zonder iets er tusschen in wat naar een boom of plant zou kunnen zweemen. Men vindt bij de woningen geen lisoengs of rijstblokken, er is één gemeeuschappelijke, met atap kiraj gedekte, loods, staande benoorden de balè, voor dat doel afgezonderd, waar al de vrouwen gezamenlijk in één prachtig-mooije, zeker meer dan 12 voet lange, lisoeng de rijst stampen. Het front van de woningen is onveranderlijk ò naar het noorden of naar het zuiden gekeerd. De rijstschuren of lëit's staan niet in de onmiddelijke nabijheid van de verschillende huizen, maar een eindtjen buiten de kom van het dorp, in de buurt van de lisoengloods, op een hoopjen bij elkaâr. Ze zijn, even als de huizen-zelf, met veel zorg bewerkt, en op houten stijlen, ettelijke voeten boven den grond uitgebouwd, an wier bovenste gedeelte, een klein eindjen beneden den vloer van de rijstschuur-zelf, noch een vrij-groote, ovaalronde, plank horizontaal is aangebracht, om de muizen af-te-weeren. Jaarlijks éenmaal (wanneer de padi in de schuur geborgen is) wordt in een kleinen klapperdop, die onder de schuur is opgehangen, en die wij er ook noch vonden, een mengsel van menjan, garoe en djämaka ${ }^{1}$ gebrand, en steekt men tusschen latwerk, tegen de zijwanden der schuren van-buiten bevestigd, drie soorten van kembang kadaka ${ }^{2}$, namelijk kakadelan, lërěp en ilat, die men soesoemping lë̈ı (d. w. z. verbergsel van de rijstschuur)

1 Benzoë, aloëhout; en 't laatste zal waarschijnlijk djambaka zijn, vol gens Rigg, een plant wier wortels als wierook worden gebrand.

2 Kadaka-bloem. 
noent, en die eveneens bij onze komst op de meeste plaatsen, hoewel in verdroogden staat, aanwezig waren.

Doch vóor ik met deze soort opmerkingen van algemeenen aard verder ga, een enkel woord over onze ontfangst en ons verblijf te $\mathrm{Tji}$ Samodor.

We vonden een zeer eigenaardig onthaal gereed staan, bestaande uit gekookte talěs, 1 in de asch gebakken pisang die een raadselachtig-groene kleur had, en een bamboezen kokertjen voor ieder van ons-beiden met pěém, ook-wel wajoe of toevak geheeten, en van den lahang of eigenlijken toewak onderscheiden, doordien er een boemboe, zekere boomschors, in wordt afgetrokken. Een eigenaardige bizonderheid met betrekking tot die pě̌m is, dat dagelijks om twaalf uur al de mannen, oud en jong, bijeenkomen, om in een bamboezen koker of lodong, batjok geheeten, die pě̌m onder zich te laten rondgaan, en hun zoogenaamd papaïran te vieren. $\mathrm{Na}$ afloop van ons diné werd ons als thee een kopjen aftreksel van daoen Kras toelang, een soort boschblaêren, gepresenteerd, een hondenkostjen, waarbij het aftreksel van daoěn Manglèt, dat me een djaro onderwech tusschen Tjilangkahan en Lebak te drinken gaf, noch godendrank is te noemen, maar dat ik naar 's Lands wijs, zonder een gezicht te vertrekken, opdronk. Saïdan had, o jammer! mijn onsterfelijke pantoffels te Lebak gelaten, zoodat ik genoodzaakt was, den heelen avond in het kleine tentjen, dat men vóor ons nachtverblijf ten onze behoeve had opgeslagen, en dat juist groot-genoech was om de tafel en de twee stoelen te kunnen bevatten, die de demang voor ons had meêgesleept, met bloote voeten te zitten. Het was in deze hooge bergstreek na zonsondergang vervaarlijk-koud. De vooravond ging voorbij, onder vragen in het Soendaneesch gedeeltelijk door mij, gedeeltelijk door den demang, naar allerlei zaken. We hoorden allerlei, oud en nieuw. De kampoeng Tji Samodor, zeide men ons, was zes jaren geleden aangelegd, toen de vroegere bevolking van den, op Melvill's kaart van Bantam voorkomenden, maar nu lang-verlaten K. Rawajan, die eerst naar het nu eveneens verlaten Tji Kĕsik verhuisd was, zich metterwoon hier gevestigd had. De kampoeng telt 15 huizen en koeren of gezinnen; de imah-randa, d. w. z. de gezinnen van weduwen, worden niet meêgeteld. Van muziekinstrumenten zijn de tjaloeng en

1 Een bekende aardvrucht op Java. (M. 
soeling 1 boejoet; daarentegen de angkloeng (die ik dan-ook later, te Tjibeo, in de balè waar we sliepen, boven mijn hoofdeinde op een balk zag liggen) zeer-geliefd; de tarawangsa, ofschoon in den kampoeng niet aanwerig, niet verboden, en de katjapè dagelijks bespeeld. Wat de kleeding betreft, het dragen van tjelana's en sapoetangan's is boejoet; de samping of saroeng's en de barljoe's moeten eigen maaksel uit den kampoeng zijn, de hoofddoek mag ook-gekocht, maar moet blaauw, wit of zwart zijn; de mannen dragen saroeng's van polèng-aros (donkerblaauw met een witte streep), de vrouwen daarnevens ook effen-blaauwzwarte saroeng's; het badjoe moet wit of zwart of ook blaauwzwart zijn Lezen en schrijven is oubekend en boejoet, zooals trouwens zelfs daloewang (een soort inlandsch papier) is. Het sirihpruimen is niet boejoet, maar wel de tabak en het rooken, zoodat dan ook de sirihpruim van den Badoeï enkel uit sirih, gambir, pinang en kapoer (zonder bijmenging van tabak) bestaat. Het is boejoet den vuurhaard, waarop men de rijst kookt, buitenshuis te maken, men moet de rijst in huis koken. De kinderen mogen niet worden ingeënt (ditotol, gelijk ze ons dikoeris noemen) alleen voor de kinderen van de uitgestootenen is de inenting niet boejoet. Daarentegen worden de kinderen wel besneden (Ilisoenatan) door eigen bèngkon's of "bonsnyder's", waarvan er éen hier op Tji Samodor, éen te Kartawana en éen op Tjibèo is. Houten kammen zijn niet, hoornen, wèl boejoet; evenzoo bedog's wel en gobang's (wat elders golok toengkoel genoend wordt) niet, - eijeren, talěs, pisang, visch, kippen en gevogelte, vleesch van sapi bantèng (wilde koeijen) en buffels en kidang's (mentjek's) geoorloofd, daarentegen vleesch van herten, geiten, schapen en ossen, kassave (hier dangdlěr genoemd), en ook (in weêrwil van al wat de Mohammedanen zeggen) apenvleesch ongeoorloofd voedsel.

Oor- en vingerringen (tjingtjing en soeweng) zijn niet boejoet, hetgeen ik dan ook bevestigd vond door het feit, dat bijna-alle vrouwen en kinderen zich de luxe permitteeren van houten cylindertjens, iets dikker dan een dik potlood, in de ooren te dragen. Het aanleggen van sawal's of natte rijstvelden, en evenzeer van lipar's (zoogenaamde drooge rijstvelden; maar

1 Rigg: tjaloeng a musical instrument beinghalf a dozen slips of bambu fastened to a string, like the steps of a ladder and, when hung up tapped with a bat of wood; solang is fluit. (Verg. over deze muziekinstrumenten nog de Hollander, Laı:d, en Volkenkunde van Ned. Indie. I p. 382.) 
die geploegd of omgespit worden), is streng verboden, in weêrwil het terrein volgens de verzekering vau den demang zich op vele plaatsen voor het aanleggen van sawah's zoo-uitmuntend leenen zou; de rijst mag niet auders worden geteeld dan op hoema's, d. w. z. bosch- of glagahgroud die eenvoudig afgebrand wordt. Goudgeld is boejoet, evenals het nieuwe kopergeld; toen een van de Gouverneur-Generaals (ze noemen hem van der Capellen, maar het moet een látere geweest zijn) aan de hoofden der Badoeï's, die hij te Paroeng Koedjang bij zich had laten komen, een goud tientje prezent woû geven, weigerden ze doodbedaard, en hij was genoodzaakt rijksdaalders te nemen, die nóch altijd door den djaro als poesaka bewaard worden. $\mathrm{Zilver}$ is overigens, behalve als muntspecie, boejoet; daarentegen salaka niet, en eveumin de kris (ofschoon ik dezen-laatste door niemand zag dragen). Van schapen, koeijen, buffels (?), paarden en geiten mag men zelfs den $\mathrm{naam}$ niet uitspreken, laat staan, dat men ze er op na zou mogen houden, njö̈; men duidt ze enkel aan onder de algemeene benaming van tjotjoöwan, d. w. z. tamme dieren. Apen mag men, ofschoon niet eten, toch houden. Alle geneesmiddelen zijn verboden, met uitzondering van eigengemaakte van sirih, die didjampè, en in welke djampe's of bezweringsformules de eigenlijke geneeskracht geacht wordt gelegen te zijn. Er is, voor al de drie kampoengs gezamenlijk, maar éen djaro; die djaro is de middenpersoon, door wien deze kleine wereld haar zaken met het gouvernement regelt en de bevelen van het gouvernement ontfangt. Gewoonlijk kiest men er een orang dikaloearan, d. w. z. een uitgestootene, voor; maar degeen die nu sints onheuchlijke jaren, meer dan 25 zeker, die betrekking bekleedt, onze vriend Tarpi, is een Badoei van het echte soort, wien men om zijn geschiktheid indertijd boven ieder-ander gekozen heeft. Zijn regterhand en, bij ontstentenis, zijn plaatsvervanger is de kokolot, die eveneens bij keuze benoemd wordt; deze kokolot beslist tevens, zonder dat hooger beroep op iemand mogelijk is, allemogelijke geschillen, die oprijzen. - Na den girang poeöen (van wien ik reeds sprak) is in elken kampoeng de tweede in rang van degenen die geroepen zijn om in deze kleine maatschappij de eigen zaken te regelen, de girang sèrat; de derde de pangasoeh kokolot (wèl te onderscheidene van den kokolot, den pangiwa van de Mohammedaansche kampoengs; hij is altijd, niet enkel in naam, máar werkelijk de oudste). Men verzekerde 
ons, dat de kokolot, de girang sèrat en de pangasoeh kokolot alle-drie gekozen worden door de geheele mannelijke bevolking, nadat de girang poeöen vooraf een kandidaat heeft aangewezen; welke mogelijkheid er in dat geval bestaat, dat de pangasoeh kokolot dan werkelijk altijd de oudste in jaren is, bleef me een raadsel. De kleeding van die "groote meneeren" onderscheidt zich door niets van die der overige kampoengbewoners, gelijk deze-laatsten ook nooit tot den girang poeöen van zich zelf met het slaafsche koering of kaoela (= "ons uw dienaar"), hier geheelonbekende woorden, maar met het onaf hankelijke aing (ons "ik") spreken; gelijkheid, absolute gelijkheid, schijnt onbetwistbaar (het blijkt uit alles) de hoofdwet die hier heerscht. Wanneer het sakramenteele getal van veertig gezinnen, dat de drie kampoengs gezamenlijk niet mogen overschrijden, voltallig is, beslist de girang poeöen (dien men bij deze gelegenheid, de Mohammedanen navolgend? den "djoeragan" noemde) geheel-eigenmachtig, wie den kampoeng verlaten moet, om orang diloearan te worden. Ik verzuimde te vragen, of de drie girang poeöen gezamenlijk die beslissing nemen (gelijk ik vermoed, omdat de drie kampoengs gezamenlijk maar-veertig gezinnen tellen.) Men zeide me, dat, wanneer er over het een of ander tusschen de verschillende girang poeöen gedelibereerd moet worden, de beide anderen hier naar Tji Samodor moeten komen, omdat de girang poeöen hier-ter-plaatse thans de oudste in jaren is; hangt dit echter niet veeleer samen met het feit, dat Artja Domas, de heilige graven, (waarover straks) onder Tji Samodor ressorteeren (zoodat dan ook de mannelijke bevolking van Tjibèo en Kartawana bij den jaarlijkschen schoonmaaktocht daarheen, deels hierom, deels ook omdat er geen-andere weg is, over Tji Samodor moeten gaan)? Met historiesche traditıes bleek het me treurig gesteld te zijn. Men verklaarde, de namen der girang poeöen van Tji Samodor's bevolking volstrekt-niet van het begin af te keunen. Al hakkelend en stootend brachten een paar van de aanwezigen er eindelijk de volgende namen uit (die ik noteerde, om ze met de opgaaf van v. Hoëvell te kunnen vergelijken, niet omdat ik aan de juistheid of waarheid der opgaaf eenige waarde hechtte) Sanèkan, Mandjari, Manrljarè, Soedji, Djanggot, Raji, Waksir, T'arsi, Tarsan, en den tegenwoordigen girang poeöen, dien men (zonderling en wantrouwen-wekkend, niet waar?) eerst Njarsan, later Djarma noemde.

Ontrent de afkomst der Badoeì's ontfing ik even-verwarde e Volgr. IV. 
en onvolledige mededeelingen, die ik echter evenzeer, pour acquit de conscience, opschreef. Stamvader: Batara Toenggal, die een zoon had, Batara Patang Djala geheeten. Deze-laatste liet drie kinderen na: éen zoon (Dalem Lagondi) en twee dochters (Dalem poetih en Dalem Djanggala). Dalam poetih (notabene! een vrouw) werd poeöen te Kanèkès, onder den naam (of titel?) van Sanèka (een oogenblik vroeger was het Sanèkan.) Door den Sultan van Bantam, wien het ter oore was gekomen, dat er daar een poeöen was, opgeroepen, werd hij aangesteld tot poeöen te Serang. Zijn zoon, Mandjari, wordt poeöen te Baros; diens opvolger Soedji (waar of Mandjarè gebleven is?) te Pandeglang. Djanggot verhuist naar Lantjar. Raji achtereenvolgens naar Batoe Karoet, naar Tji Larangan, naar Sampang pĕndĕj, naar Bodjong Kopo (in Lěbak.) Waksir, evenzeer met de verhuismanie behebt, sukcessievelijk naar Tjatang, naar Tji Tangtoe (onder K. Tji Boengoer), naar Kadoe hělang, naar Babakan (onder K. Bodjong Mèntèng), naar Badoei, naar Tji Sèrè (beiden in de buurt van Bodjong Mèntèng). Tarsi op zijn beurt, eerst naar Tji Palèr, daarna naar Tji Bokor, van daar naar Rawajan, en van Rawajan naar Tji Běĕng. Tarsan eerst naar Tji Kĕsik (men zeide eigenlijk: moeara Tji Kĕsik), van daar naar Bantar Waroe (vlak-bij Tji Samodor), en vervolgens naar Tji Samodor.

We besloten den toekang pantoen te laten komen. Het was een jongen van hoogstens 20 jaar, met een allerinnemendst uiterlijk en een prachtige stem; niets van dat gillende, krịschende, waarmeê de inlandsche zangers in-den-regel mijn ooren verscheuren. In den beginne was hij blijkbaar verlegen, en kuchtte en hemde gedurig, evenals een burgerman-nutredenaar in ons dierbaar vaderland. Maar dat ging langsamerhand over, en toen zong hij uit volle borst, onder begeleiding zijner katjapè (een soort van inlandsche gitaar, waaraan hij zeer melodienze toonen wist te ontlokken) een van die diep-weemoedige liefdesgeschiedenissen van een vorsten-zoon en vorsten-dochter, die allen in de dagen van lang vervlogen grootheid en zelfstandigheid spelen. Wanneer hij, bij het uitbrengen van hooge toonen, het geluid moest dempen door de hand aan den mond te brengen, hield hij (dit frappeerde me zeer) zijn hand nooit, gelijk ik zou verwacht hebben, aan onzen kant, maar aan den tegenovergestelden, waar het huis van den girang poeöen stond; een aardig blijk, dat hij geen hooger gezach kende of erkende 
dan dat van zijn girang poeöen. We bleven lang, misschien wel twee uur, zitten luisteren; maar het zou een hopeloos iets zijn geweest, op het eind te willen wachten, daar de geschiedenis (gelijk de demang me zeide) wel tot den volgenden ochtend zou duren, nu "de kraan éens los was." We gingen dus ten laatste maar naar bed, teu einde ons daar door zijn gézang op eene aangename wijze in slaap te laten wiegen. - Ik zeg: naar bed, maar dit is voor hetgeen we vonden een zeer oneigenlijk woord. Verbeeld $\mathrm{u}$, twee bultzakken van den demang, op den grond neêrgelegd; gescheiden door een grof, doorzichtig, eigengemaakt stuk ongebleekt katoen (spreijen of iets van dien aard, dat naar gekleurd katoen leek, mogt niet door den demang worden meêgebracht, dat was boejoet); overdekt met een mat van gevlochten bamboe (rotanmatten zijn boejoet); en voorts op ieder van die bultzakken, drie kleine rolkussentjes (groote) zijn boejoet, evenals de bultzakken bij de Badoeï's zijn van kapoek randoe, vuil en zonder eenig overtrek.

\section{LOSSE AANTEEKENINGEN TIJDENS HET BEZOEK BIJ DE BADOEÏS.}

De uitgestootenen mogen met Mohammedaansche vrouwen trouwen.

Een kwartier lang zeker door de bedding van de Tji Samodor heen. Daarua weêr glagahpad, maar nu enkel doorkruising van de Tji Samodor.

We dalen langs een steil en glibberig pad in de Tji Sadjèra af, en moeten die, op een punt waar ze zeker 100 voet verval heeft, langs steile glibberige rotsblokken naar beneden klouteren, om haar overlangs een heel eind te doorwaden. Aan het eind van dit doorwadingsproces, prachtige, breede, kom.

Oneindig klimmen door prachtig bosch; diepe, begroeide ravijnen flauw zichtbaar.

Spookachtig; maar vriendelijk een zonnestraal hier en daar.

Geweldige daling naar de Tji Oedjoeng, de grens waar de Badoeî's aan hun natuurlijke behoeften kunnen voldoen. Talahab ${ }^{1}$ aan de overzijde. Kristalhelder bruischt het water over breede rotsblokken. Prachtig wild bamboebosch. Groen bemoste steenen. Liarien, zich van de takken van het hoog geboomte welvende over het bruisend water.

1 Rigg: a roofing, made of split bambu; dus een soort loods? 
Noch een groot kwartier verschrikkelijk-moeilijke tocht, door de bedding van den Tji Oedjoeng naar Artja domas. 9 mannen eenmaals 's jaars, boelan kalima, 17de. Blijven 2 nachten schoonmaken (onder den girang poeöen met de handen, anders mag niet.) Maar den tweeden dag blijven ze in de talahab, om te sidekah.

Pètak's ${ }^{1}$, met door menschenhanden aangelegde steenhoopen, begroeid met loetoek, en de pètak's beplant? met djěngkir.

Pètak no. van boven 1 graf.

Pètak no. 2 smal, niets.

Pètak no. 3 groot, 5 grafhoopen. Vierkant. Een schuin uitstekende steen met mos begroeid.

Pètak no. 4 en 5 smal, klein, niets.

Pètak no. 6 sasaka pakoembahan tĕ daèkěn saäl, een rond postjen, djalli koe manèh, met mos begroeid, 2 graven met opstaande steenen.

Pètak no. 7, 8, 9, klein, niets. Evenzoo 10, 11, 12, 13. Prachtig bamboe rondom. Zoomt Tji Oedjoeng, aan de zuidgrens diep ravijn, en weêr de Tji Oedjoeng.

De pètaks loopen van noord naar zuid op.

Op den teruchweg komen we langs taněh poetih teruch aan de talahab.

Doodmoede 's middags om 4 uur weêr thuis, - 's avonds vizite van den girang poeöen, die door den demang belet laat vragen. Hij zegt. dat de Badoeï maar-éen vrouw mogen hebben, waarvan ze echter scheiden mogen, en die dan op nieuw trouwen mogen; dat echter echtscheiding onder hen een groote zeldzaamheid is. Dat ze zich zelf oerang Para Hiang, de buitenwereld oerang arè 2 noemen. Dat ze hier zes jaar wonen. Dat er door girang poeöen beslist wordt, of men verhuizen moet; en dat alsdan de paradji, hier doekoen genaamd (een man, de eenige die er zijn mag; en wonende te Tji Samodor) de keuze heeft en de aanwijzing doet van de nieuwe woonplaats. Dat de huwelijken door den poeöen (dien hij met den pangoeloe der oerang slam (Mohammedanen) vergeleek) gesloten worden, die ook echtscheiding regelt. Dat ze niet gelooven aan een leven na dit leven; dat volgens hen de mensch troes paèh baè ${ }^{3}$,

1 Rigg: a garben bed, a bed of anything planted.

2 Rigg: the people living in open country.

3 Door en door dood. (M.) 
maar dat de goede dooden naar Artja Domas, de slechte (eerst zeiden ze: we weten niet waarheen), later naar de kawahs gaan. Dat de huizen volgens éen model gebouwd moeten worden. Dat de girangpoeöen geen geschenken hoegenaamd mogen aannemen, wel de anderen. Dat ze een maanjaar hebben. Dat ze mentjek (kidang) wel mogen eten; alleen herten (die ze menjangan niet oentjal noemen; evenals de djambè pinang, de paradji doekoen) niet. Dat hun maanjaar van oogst tot oogst schijnt te loopen; althans hun oogstfeest, dat ze koewaloe noemen, begint met den eersten dag van de maand Kasa, de eerste van hun jaar; en duurt drie maanden lang (?) Vrouwen en mannen vieren het gesamenlijk en in de kampoengs.

Groote zindelịkheid in de huizen merkte ik op; en vóór dat men van de golodog 1 in huis stapt, wasschen of liever afspoelen van de voeten met het water uit de lodongs ${ }^{2}$, die altijd bij de deur staan.

Ik zag bij den girang poeöen een vrouw op de balè-balè met de mannen zitten praten.

Na de sirah ${ }^{3}$ Tji Kĕsik te zijn doorgewaad, zien we op een hoog punt voor ons de hoema sèrang liggen (waar al de 40 man éen dag njatjar, noewaran, bakar, ngadoeroek, ngasek, ngorèt, diboeat, motjong, ngangkoet. ${ }^{4}$ De girang sĕrat oeroei’t de bewerking van deze hoema sèrang.

Er zijn drie hoema sèrang op de drie plaatsen.

Het toemboeken óok éen dag, maar alleen door de vrouwen van de plaats; eveneens het koken éen dag, eveneens het eten (dat echter later hervat kan worden, als men het niet op kan).

Het padizaad mag niet verwisseld worden; koedoe pagon baè. ${ }^{5}$ Behalve als ze koopen. De Tji Samodorders b. v. altijd zaad van daar.

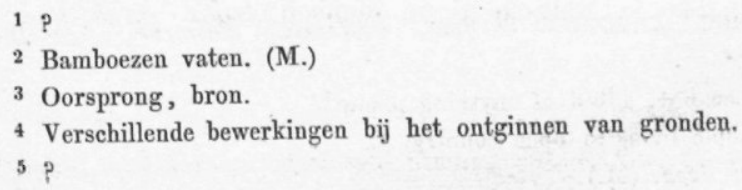


$\mathrm{Na}$ de sirah Tji Kĕsik, gaan we hem noch-tweemaal door. Daarna ongeiooflijk-lange en vrịj steile klimming. Doorwading van de kleine Tji Doelang, en de breede, vreedzame kristalheldere Tji Bŭĕng, de grens van het Tji Samodorsche.

Aankomst langs een zijpad te Tji Kartawana.

Maar 5 koerèn, de imah randa, huizen van weduwen, niet. meêgeteld.

Het wegen van padi door een kommissie noemen ze boejoet, en gebeurt ook niet.

Van Garoegoeg hierheen verhuisd voor 8 jaar.

De Tjibèoërs daarheen verhuisd van Kanèkès.

Van Tji Kartawana naar Tjibèo. - Een klein eindtjen. De redelijk-smalle Tji Parahiang over en we zijn er.

Ik zag hier badjoe's (djamang's) gemaakt van draden van de tangkol pèlah 1 (waarvan echter de mouwen altijd van wezenlijk garen moeten gemaakt zijn); evenzoo zag ik samping ${ }^{2}$ pèlah. Gewasschen kan het niet; dan wordt het boboh.

Te Tji Lèngger en te Lengis worden die dingen ook gedragen, te Tji Samodor vooral, meer dan te Tjibéo.

Er zijn noch acht poeöen's van de.oerang dikaloearan; nl. te Sangkan Wangi of Kamandjing of Tji Handam, Tji Lènggor, Noengkoelan, Tji Patik, Padawaras, Garoenggag, Inggoeng, Tjaroengĕn of Marèngo. Allen zijn ze onderworpen aan den girang poeöen hier te Tjibèo. Bij elke koewaloe (zie boven), dus driemaal 'sjaars, den 17 den van de maand Kasa, en den 18 den van Karo, den 17 den van Katiga moeten die negen (acht)? poeöen's, ieder met twee van hun tëmĕn's naar Tjibèo opkomen. Drie er van (Padawaras, Tji Patik, en Kadoekoedjang $=$ Ing. goeng) moeten meêbrengen oejah (zout) en trasi; niets meer.

Volgorde der maanden. Sapar, Kalima, Kanem, Kapitoe,

1 Naam van een rotansoort (?)

2 Ml, Saroeng. 
Kadalapan, Kasalapan, Kasapoeloeh, Hapit hemat, Hapit Kajoe, Kasa, Karo, Katiga. - "Tanggal tahoen boelan sapar" (Nieuwjaar is in Sapar).

De hoema sèrang wordt gesneden in de maand Hapit Kajoe de andere in de drie volgende maanden. In de maand Sawal (Sapar) is het padisnijden afgeloopen.

In de maanden kasa en kaliga maakt men een laksa, in de maand karo niet.

Ook de 9 buitendorpen hebben ieder hun koewaloe, en wel op den 21 en dag van de boelan Katiga de poeöen's van Garoeggag en Sangkan Wangi (ieder afzonderlijk); - op den 22n die vam Kasue hělang (= Padawaras) en van Inggoeng; op den 23n die van Tji Patik, Marèngo, en Tji Lènggor; - op den $24^{\text {n }}$ die van Noengkoelan, op den 27n die van Kamantjing (een ampihan van Sangkan Wangi).

De methode van viering dezelfde als in de binnenwereld.

2 anak-anakan dari lepoeng (2 poppen nevens elkander?) 1 man, 1 vrouw.

1 langgir, boeat toenggangnja (schorpioen als rijdier) van het mannenbeeld, (Ml. kalarjengking) levend.

1 lantjah (adder), boeat toenggangnja van het vrouwenbeeld, levend.

wajoeh, (pе̌еm) als drinken voor man en vrouw; saboengboeng.

Saboengboeng water, voor hetzelfde doel.

1 běntjěh (groote djangkrik's heeten in het Sdn. kasir; deze zijn bèwok) als eten. (Rigg. eggplant).

1 tjokrom (tèrong), solanum melongena als eten.

1 sauhěn bĕnang ngoeloeb, idem. Sauhĕn is panicum palmaefolium. (Rigg.)

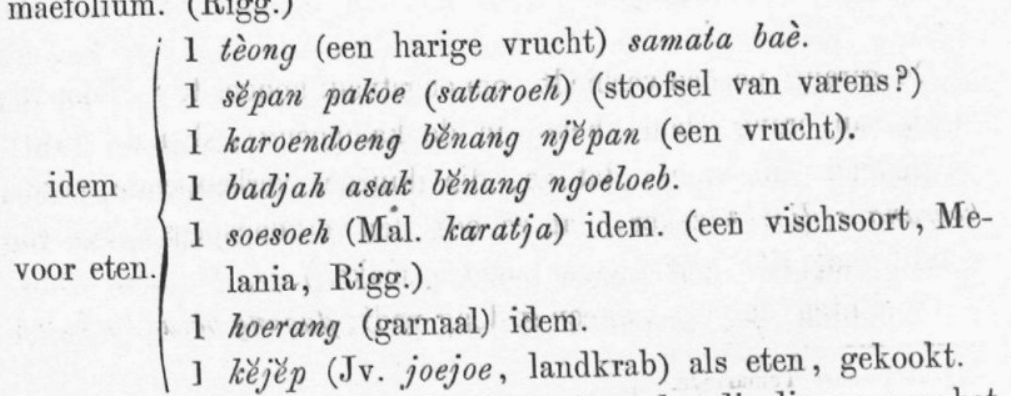

O.p de laatste kawaloe (in Katiga) worden die dingen naar het bosch gebracht, als een diner voor de pa amoenggoe (geen 
sètan's, maar batara batara, noe aja di guenoeng goenoeng; "baris dewa dewa)" na afloop van de koempoelan (vergadering).

De luksa wordt eveneens op de laatste kawaloe door al de vrouwen gemaakt, van meel met hasem honjè ${ }^{1}$; toeloej dirěntjĕt, toeloej ditandèan koe parioek di handapěn djambangan (= tjitakan laksa); sanggěnsa djadi laksa, bidjil tina-djambangan tèa toelvej dibawa kaljai, dikoembah (diberesihan); toelorj diwadlahan, dibawa kaimah, dirioeng, en wordt opgegeten.

Njèrè kawoeng (lidi arèn, Holl. nerf der palmbladeren) wordt rondom de 2 beelden in het bosch gezet. Djoemblahna noeroet koemaha lobana djelma noe aja di lemboer iě (nl. in het dorp dat feest viert, de van-buiten-komenden worden niet meêgeteld).

De njèrè kawoeng worden ditantjelkèn (rechtop in den grond gestoken) van onderen, maar zijn, hoewel speeren reprezenteerende, van-boven niet gepunt, niet tjara toembak.

De Heeren Tobias (Resident van Banten) en een adsistentresident van Lebak, dien ze Sepanol noemden, de éenigen die voor mij te Artja Domas geweest zijn.

De pasir, waarop de Artja liggen, heet pasir Domas.

De girang sèrat precies een gezicht van een Hindoesche pagode. Ontmoeting met den girang poeöen en de heele mannelijke gemeente, vergaderd om een nieuwen djaro te kiezen.

Bezoek in een inlandsche woning, waar de vrouw des huizes minzaam met ons praat.

De girang poeöen verbiedt, om oogstpadi hooger te verkoopen, hetzij aan orang slam, hetzij in de kampoengs, dan 14 duiten de gèdèng; uit vrees, dat ze, die duurder verkoopende, zullen koerang redjeki 2 (zeker, dat ze ook den verkoopsprijjs in tijd van nood, voor zich zelf hooger zouden maken).

14 duiten de prịjs van een gèdèng padi, dagang beras boejoet ${ }^{3}$.

1 Een soort Tamarinde.

2 Gebrek aan levensmiddelen krijgen. (M.)

3 In rijst te handelen is boejoet. (M.) 
Buiten de buitendorpen waar girang poeöen's zijn, zijn er noch onderscheiden (Tji Palěr, Tji Kadoe, Tji Hoeloe), waar er geen zijn, doch waarvan de menschen bij gelegenheid van de koewaloe eveneens hierheen komen.

De hoemagronden van Tji Kertawana en Tjibèo zijn gemeenschappelijk en door geen grens gescheiden.

Vóor het vijftiende jaar mag jongen noch meisje trouwen.

v. Hoëvell werd genoemd toean pangoeloe.

\section{VERVOLG VAN HET JOURNAAL.}

20 Juli... In en nabij de hoofdplaats hadden we gelegenheid, op nieuw de verregaande onbeschoftheid van den Noordbantammer op-te-merken. In weerwil van den zilveren band om B's pet, hielden de mannen geregeld hun soedoeng ${ }^{1}$ op het hoofd, en bleven degenen, die op een paard ons voorbijkwamen, er doodbedaard op zitten. We ergerden ons om-het-zeerst. Gelukkig, dat het vriendelijke landschap ons van zelf langsamerhand in een aangename stemming bracht. Hier geen spoor van wildernissen, van kale of met dorrend rietgras begroeide heuvels, van sombere bosschen of diepe, steile ravijnen; maar overal, waar men het oog liet weiden, elk plekjen benut door noeste menschenvlijt. De zachtgolvende landstreek, waar de weg zich door heen slingert, een aaneenschakeling van de prachtigste sawahs, waarvan het, in rijken overvloed voorhandene, water hier naauw-hoorbaar afzijpelt, ginds in schuimende vaart omlaag stort. En die sawahs overal gestoffeerd met manggahs, wier prachtige kroonen en donker loof, vooral waar het lichtgroen van de pas-ontkiemende zaaipadi er tegen uitkwam, aan het geheel een allerbetooverendst voorkomen gaf, zoodat men zich gedurig in de nabijheid van een Engelsch lustpark verplaatst waande. En daarbij telkens in deze rijkbevolkte streek kleinere of grootere kampoengs, waaruit het gezellig geluid van den rijststamper zich hooren deed; en onder de schaduw van het ge-

1 Groote ronde strooijen hoed (?) elders toedoeng (M.) 
boomte hier-en daar een paar vreedzaam-grazende buffels met hun kleine geleiders; en op de velden de nijvere landbouwer overal bezig, in het zweet van zijn aanschijn met vrouw en kinderen te arbeiden; waarlijk, men zou een Barend Ovink moeten zijn (wiens eerste indruk van het Haagsche bosch zich in deze woorden lucht gaf; "he, als dat eens werd omgehakt! Ik wed, dat men er meer dan $f 100,000$ voor krijgen zou"), om te midden van zulk een liefelijke natuur, aan de weligste en vriendelijkste landouwen van ons dierbaar Europa herinnerend, ongevoelig te blijven.

In de ruime, koele, met glasruiten en chineesche windjalouziën voorziene, passanggrahan te Petir op luijaardstoelen uitgestrekt, rakkten we met den demang aan het praten over de kaneelkultuur. Hij ijverde zeer voor haar behoud, omdat de grond hier (volgens hem) voor alle andere kultures te slecht is (de koffi, zeide hij, na eerst magnifiek te zijn aangeslagen sterft geregeld in het derde of vierde jaar), en omdat de kleine man aan de kaneel nu tenminste noch-iets verdient. lk vernam van hem, dat de kaneelschillers een vast corps vrouwen zijn, wier loon $f 2.50$ 's maands bedraagt (dus evenveel als bij de vrije theekultuur); dat de aanplant noch onlangs is uitgebreid, en nu in zijn distrikt, ik meen 150 bouws bedraagt; dat er onder de kaneeltuinen zijn, die dertig jaar, en noch altijd uitmuntend, staan (afdoende wederlegging van de modebeweering, dat de kaneelkultuur moet worden ingetrokken, omdat ze den grond zoo uitput); dat de inspekteur der Kultures W..., die hier onlangs in commissie geweest was, hem de intrekking als aanstaande had voorgesteld, maar dat hij dringend verzocht had om haar (zonder Europeesch personeel desnoods, ter besparing van kosten) in-stand-te-laten.

Onder dat Europeesch personeel moet ook een "assistent bij de kaneelkultuur", die bij hooge feesten een mooijen rok draagt (gelijk ik gelegenheid had te Serang op-te-merken), en $f 300$ 's maands heeft, gerekend worden.

$\mathrm{Na}$ eene voortreffelijke rijsttafel vervolgden we, nu onder de hoede van een paar dorpshoofden, onzen tocht. Het was gloeijend en broeijend heet; het "keerkrings-middaguur " en de zon met haar verzengende stralen veroorzaakten me een ondragelijke hoofdpijn. Ik had naauwelijks oog meer voor de schoonheden van het, ook-hier-noch, rijke en vruchtbare landschap. Aan de gardoe Tji Sorok wachtte een mantri van Waroenggoeuoeng 
met een talrijk gevolg ons op. Het eerste, wat men er ons aanbood, was toewak, waarschijnlijk ter eere van den plaatsnaam (sorok heet de buis, waarin de toewak wordt verzameld); ook was er een heel diné voor ons heengesleept, waarvoor we echter (daar we geen kameelen waren, die over vier magen te beschikken hadden) vriendelijk bedankten. Tot dicht-bij Waroenggoenoeng behield het landschap zijn vruchtbaar en vriendelijk voorkomen, althans gedeeltelijk; maar van-nu-af, en steeds-sterker naarmate we Rangkas Bitoeng naderbij kwamen, kreeg het terrein den eigenaardigen stempel van 'Zuidbantam's dorre, waterlooze en onbevolkte wildernissen.

21 Juli. Om zeven uur op, en rijd met den reiswagen, eerst, denzelfden weg langs als gisteren, tot Waroenggoenoeng, en van daar (in-plaats-van rechts af te slaan, naar Petir) recht door, den weg naar Pandeglang af, noch twee palen ver, tot-aan de gardoe Sampaj. We slaan nu links-af, en rijden, over een modderigen weg, maar door een allerweligste sawahstreek, tot-bijna aan de gardoe Moentjang, 4 paal ver, toe. We passeeren sukcessievelijk den kampoeng Sampaj, een ampihan van dien kampoeng, Tji Boeah geheeten, den $\mathrm{k}$. Tji Sono, den k. Tji Bangkoer, aan weêrzijde van de, misschien twaalf voet breede en één voet diepe Tji Kondang gelegen, die we doorwaden, den k. Kontjang koelon en Kontjang wètan, de Tji Koepa, die we door-middel-van een brag overgaan, en den k. Tji Loetoeng; totdat we eindelijk aan de gardoe Moentjang Kopong, ressorteerende onder den k. Tji Koeloer, aankomen. Even-vóor de Tji Koepa verandert het waterrijke van sawahlandschap in een golvende, heuvelige tiparstreek, gelijk ik ze in Bantam, waar de hoogvelden veelal, hetzij met harèndong ${ }^{1}$ en hooge alang-alang, hetzij met hoog geboomte bedekt zijn, noch-niet gezien had, maar waarin de wadasformatie, die in de Zuid van Bantam zoo-volstrektalgemeen is, zich toch niet verloochende. Van gardoe Moentjang Kopong reden we, door tipars en glagah, zonder bijna een dorp op onzen weg te ontmoeten, zes paal verder tot-aan gardoe Goemoeroeh. We passeerden den Tji Panas; den k. Anggalan aan déze, den k. Tji Bogoh aan géne zijde van den Tji Lantjar; den k. Woeloekoe, en den Tji Woeloekoe, na alvorens zuid.

1 Een soort laag gewas op open vlak terrein groeijend. Ml. Sikadoedoek. (Melatma Malaba thrioum), Rigg. 
waarts loopende binnenwegen van Sampaj, alsmede van Pandeglang naar Lěbak gekruist te hebben; den Tji Marikoe; de grens van het Paroeng-koedjangsche; de Tji Tjanggong, en komen zóó eindelijk aan de gardoe Goemoeroeh, waar mijn eergeleide verwisselt, en vanwaar het noch een heel eind is tot de kampoeng Goemoeroeh, dien we, langs een, expresselijk voor deze gelegenheid vervaardigden, fantazieweg, midden door velden en plantsoenen heen, bereiken.

21 Julij. (vervolg.) Van Goemoeroeh vervolgde ik mijn weg naar het, noch acht paal verwijderde, Koempaj. Ons pad liep voortdurend over bebouwde hoogvelden (tipars) of braakliggend hoogland, nu met frischgroene alang-alang begroeid, en rijk beplant met heele bosschen van vruchtboomen, vooral doerians en katjapi's 1, die daar in den loop des tijds door de, gedurig tot verhuizen gedwongene (een tipar kan eerst in het vijfde jaar na zijn bebouwing hier op nieuw bebouwd worden) bebouwers dezer hoogvelden geplant zijn, en die nu, terwijl ze een alleraangenaamsten indruk op het oog maken, tegelijk een milden schat van vruchten afwerpen. We passeerden sukcessievelijk den k. Tjoeroeglajang, de Tji Dokdok: de Tji Tjanglaj; den k. Gantoengan; de Tji Silad; de Tji Rawoehĕn; de Tji Sanintĕn; de Tji Moenoen; de Tji Tjèrèn; en de Tji Tĕrĕp (allen kleine spruitjens, waarvan dan ook enkel de twee voorlaatsten en de Tji Rawoehěn met een brug voorzien zijn) en kwamen eindelijk tegen zeven uur, in stikdonker, te Koempaj in de pasanggrahan aan.

22 Juli.... 's Middags lees ik de Woelang-tani noch-eens, en doe daarna een wandeling door Koempaj, een allerliefst dorp, weiks huizen tegen een woud van klappers en andere vruchtboomen, waartusschen ze inliggen, allerbevalligst uitkomen. De pasanggrahan ligt op een soort van hoogte of heuvel; een zeer mooi punt, vanwaar men uit de voorgalerij een zeer mooi gezicht op de, er tegenover in een diepte liggende, kampoeng heeft: 's Avonds heb ik, van zevenen tot twaalven, konferentie met de hoofden en dorpspriesters uit de kaloerahan Koempaj, met wie ik het eerste gedeelte van de Woelang-tani bespreek.

23 Juli.... Daarna, van half-acht tot twaalven voortzetting en ten-einde-brenging der lektuur van de Woelang-tani...... $\mathrm{Om}$ vier uur op weg naar Bodjong. Nadat we op een èrètan

1 Rigg. Sandoricum Nervosum, 
de, ook-hier noch waterrijke Tji Lèmèr zijn overgestoken, zijn we welhaast aan de greusscheiding van Menès en Paroengkoedjang. Noch een klein eindtjen loopt onze weg door vlak hoogland; maar zoodra we aan den pasar van Bodjong, ressorteerende onder den k. Tji Djakan, zijn gekomen (noch een paar paal van Bodjong bijna), verandert het toneel, en rijden we door een breed, effen, door vruchtboomen aan weêrskanten dicht belommerd, pad verder. Het is een allerliefelijkste natuur, en het spijt me, te-meer omdat het op dit uur zoo-verkwikkend koel is, dat we zoo-spoedig aan de plaats onzer bestemming zijn.

24. Juli. Aanvaarding van den tocht naar Moendjoel. Over het geheele omliggende landschap hangt een geweldige nevel; de demang zegt, dat dit elken morgen tot acht, negen uur het geval is. We moeten tot-aan den pasar van Bodjong (dus bijna twee paal) denzelfden weg teruch rijden, dien ik gisteren g ek omen ben. Had S. me de door mij gevolgde reisroute niet opgegeven, ik zou hoogst waarschijnlijk van Koempaj rechtdoor naar Moendjoel gegaan zijn. Maar dat zou me van een groot genot beroofd hebben. Niet-alleen had ik dan dezen prachtigen weg gemist; maar bovendien het liefelijk gekweel van de tallooze zangvogels, dat zich dezen ochtend van uit het geboomte langs ons pad hooren deed. Ik woû, dat de voortplanters van den traditioneelen leugen: "Java heeft mooij e vogels, maar ze zingen niet", bij me geweest waren, ze zouden voor-altijd ophouden die infame leugen te debiteren. Zoodra we den pasar van Bodjong voorbij waren, sloegen we rechtsaf; en zie, eensklaps was het gedaan, en voor-goed gedaan, met de schoone natuur, waarin ik me zoo verlustigde. Van nu-af tot Moendjoel toe liep onze weg (eigenlijk niet-anders dan een voetpad, met alang-alang begroeid) bijna uitsluitend door manshooge, ondoordringbare glagah (alang-alang, kaso-kaso, en wat struikgewas), een veilige verblijfplaats voor tijgers. Gloeijend brandde de zon op ons schaduwloos pad, waar geen tochtjen kon doordringen, en welks vermoeijende eentoonigheid nergens door een voorbijganger, zeldenof-nooit door een dorp of gehucht werd afgebroken. Het ontmoedigendst van alles was noch het bewustzijn, dat van deze waterlooze landstreek, die zich uitstrekt, zoover het oog reikt, niets, letterlijk niets te maken is; dat ze in de statistieken van het Gouvernement altijd onder de "woeste gronden" zal blijven figureeren. Gedurende de eerste vier paal van onzen tocht passeerden we éen kleinen kampoeng, Goenoeng tjangri geheeten, 
$\mathrm{Na}$ die vier paal rijdens staken we op een èrèlan wederom den zich hierlangs kronkelenden, Tji Lèmèr over (het veer heet menjabrangan Kadoe pandak). Een paar minuten lang slingerde onze weg zich, even voor den vijfden paal, door mooi bosch, allen geplante vruchtboomen. Even-voorbij den vijfden paal verkwikten we ons met een klapper in de gardoe Pasar Pětjoeng (te Bandoeng zegt men: pitjoeng). We kwamen in die buurt twee, noch naamlooze, kleine nederzettingen van overloopers uit het Paroengkoedjansche voorbij, waarop de demang me met kennelijken trots wees. $\mathrm{Na}$ een kleine boeht beschreven te hebben, rechts af, kwamen we aan een kruisweg, vanwaar rechtdoor naar k. Madoe malati, rechtsaf naar Kadoe pandak (den kampoeng van dien naam), door vruchtboomen liefelijk-belommerde padeu voerden, terwijl wij linksaf sloegen door een eeuwigonveranderd glagahlaudschap, waarin geen verandering zichtbaar was dan deze: dat de glagah hier lager was, zoodat we zien konden, hoe-eindeloos-ver ze zich uitstrekten. Aan den zevenden paal (het leek me wel twintig door de verveling), te Kolèlèt, een ampihan van den $\mathrm{k}$. Kadoe pandak, hielden we halt, daar hier de grensscheiding van Menès en Panimbang was. We passeerden nu (over bruggen) den Tji Poerang, en den Tji Mojan; aan géne zijde van deze laatste rivier den k. Soepakalang. Daarop reden we een pooslang door onmenschelijk, ik wil zeggen : bovenmenschelijk-hooge alang-alang (een waar tijgernest, gelijk men me zeide); een heel klein eindtjen, misschien vijf minuten lang, door mooi, hoog bosch, maar waar de weg uit een aaneenschakeling van modderkuilen bestond, zóo-week en drassig, dat hij bijna-overal belegd was met houten staken, door twee zijdelingsche staken tot zoogenaamde ramen verbonden (voor de paarden een minder-pleizierig experiment); en vervolgens natuurlijk weêr door alang-alang, tot-aan de gardoe Djajrah (behoorende onder den, links van den weg vlakbij zichtbaren, $k$. Pasir Tèndjo) toe. We hadden nu weêr vier paal afgelegd, en noch acht paal voor de boeg. Gedurende de eerste vier paal niets opmerkenswaardigs, dan-dat we vier spruitjens, kleiner dan een Hollandsche kikkersloot, overtrokken, den Tji Sempoerĕn, den Tji Hèrang, deu Tji Soeloek, en den Tji Tepoesĕn, die de absolute waterloosheid dezer landstreek noch sterksprekender deden uitkomen. Gedurende de vier laatste palen een noch-dorder landstreek, waarvan het eenig-opmerkelijke was, dat we een paar treurig mislukte Gocvernements-koffiaanplantingen voorbijkwamen, die me 
heriunerden aan het woord van den demang van Menès, dat de koffi in dezen slechten streek niet groeijen wil; dat hij, gedurende de negentien jaar van zijn demangschap, misschien wel honderd duizend boomen geplant had, maar altijd vruchteloos; dat geregeld in het derde, vierde jaar, als de dunne humuslaag is uitgeput, de koffiheester sterft. $\mathrm{Nu}$ noch den kleinen Tji Salap over, en we zijn aan den kalmen, maar frisch-kabbelenden, en zeker achttien voet breeden Tji Liman, en na dien met een èrètan te zijn overgestoken, te Moendjoel. - Aan den oever wachtte me een goed deel van de mannelijke bevolking op, dat (voor het eerst op mijn reis ondervond ik dat eerbewijs) ten teeken van hulde mijn rechterhand even tusschen zijn twee saamgevouwen handen nam, en daarop die saamgevouwen handen naar het voorhoofd bracht. De pasanggrahan is een vuil, oud, vervallen krot, waarbij vergeleken de toren van Pisa noch récht staat. Een half uur ná mij, aankomst van den demang, natuurlijk rechtstreeks van Panimbang.

25 Juli. ..... Van zevenen tot twaalven voorlezing en bespreking van de Dongèng-Dongèng........ Van half-acht tot half-twaalf breng ik voor een half-slapend gehoor (gelukkig bleven enkelen wakker) de lectuur van de Dongèng-Dongèng ten-einde.

26 Juli. Van Moendjoel naar Kĕsik. Het heeft den heelen nacht geslagregend, zoodat het eerste gedeelte van ons smalle voetpad een ware modderpoel is. We grasduinen onmiddelijk weêr in de glagah, en de allervervelendste weg onderscheidt zich in niets van dien tusschen den Pasar van Bodjong en Mendjoel, behalve dat hij door een, zooveel-mogelijk nochonbevolkter, streek loopt, en tegelijk (een teeken dat we, hoe-langs hoe-meer, zuidwaarts komen) door een veel-heuvelachtiger landschap, vol up and downs. Op sommige van die heuvelhellingen kreeg ik weêr van die eigenaardige vergezichten die me in Luebak zoo-dikwijls moê en suf gemaakt hebben: een vaalgraauw landschap, uit een aaneenschakeling van bosschen en bergen bestaande, zonder kleur of tint of leven, zonder iets waar het oog op rusten (ik zeg niet-eens: met welgevallen) blïft., Wij gingen, even-nadat we Moendjoel verlaten hadden tweemaal met een vouder den Tji Bělah over, reden daarop een eind langs den (steilen) oever van den Tji Liman (dien we links van ons hadden) voort; passeerden het kleine Tji Dilem, een ampihan van den $\mathrm{k}$. Doekoek; doorwaadden den smallen 
en bijna waterloozen Tji Dilem; trokken de lorah Soedimara, de lorah Soeroeg langgeng, de lorah Tji Boengkang (verzamelkommen van wechzakkend regenwater) over; ontmoetten noch het kleine Tjoeroeb langgeng, een ampihan van Soedimara; beklommen daarop een vrij-steile heuvelhelling, die we, dwars over beploegde tipars heen, overtrokken; en kwamen zoo (na noch de smalle Tji Soekawali en de plek waar vroeger de nu verplaatste dessa van dien naam gestaan heeft, nu in tipars herschapen, gepasseerd te zijn) aan de grens van het T Tji Balioengsche. We waren nu acht paal ver. We gaan den kleinen Tji Karonjo over. Van den k. Panjatjaran (die, o wonder! links van ons pad tusschen een liefelijke groep vruchtboomen verscholen ligt) zit de heele mannelijke bevolking aan den weg en neemt eerbiedig miju linkerv oet (!) tusschen de saamgevouwen handen. We doorwaden den ondiepen Tji Panjatjaran, gaan de Tji Bĕrĕm over, het gehucht van dien naam (ampihan van Pasir Eri) door; eten in den k. 'Tji Paäs (vier paal voorbij de grens) wat limoe's en katjapi's; ontmoetten op onzen, noch vier paal langen, weg, noch de Tji Idjěw, de Tji Kolèlèt, de Tji Běrĕm, de Tji Kaloedan lětik en gedè, het gehucht Kaloedan (ampihan van den k. Tjoeroeg Tjioeng) den Tji Hajer, den k. Tjoeroeg Tjioeng (dien de demang pas, met vaderlijke zorg, maar tegelijk een aardig staaltjen van den kinderlijken toestand der maatschappij, een eindtjen heeft laten verplaatsen, omdat de menschen op de vroegere plaats altijd ziek waren), den Tji Balangbang, en den Tji Bĕntĕr ; riviertjens of spruitjens, allen veel kleiner dan hun namen, die u zeker wanhopig zullen maken, en die ik hier toch, nom een reden," moet opnemen, gaan met een bamboezen brug (een houten, zeide de demang, zou een dwaasheid zijn, omdat hij met bandjirs toch geregeld zou wechspoelen) de, lágerop wateren vischrijker, maar hier ondiepe, en hoofdzakelijk met steenen en modder gevulde Tji Kĕsik over, en bevinden ons in den kampoeng van dien naam, waar ik in de kleine, maar nette pasanggrahan afstap (die echter éen groot inkonvenient heeft, dat er geen enkele deur aan is).

27 Juli... De lucht ziet overal even-dik, en daarom wacht ik het opklaren van het weêr maar niet af. Ik wapen me tegen modder en nat, door blootvoets te gaan, en met niets dan een kabaai en een nachtbroek aan. Het is vinnig-koud, en ik zit te bibberen op mijn paard. We zijn allen welhaast ridders van 
de droevige figuur, zoo verwaaid en verregend zien we er uit; ook de heeren van mijn geleide, allen gekleed in hun mooije dienstpak. De weg is natuurlijk slibberig en glibberig, maar loopt tot aan de gardoe Tji Soeakan (ressorteerende onder den, van den weg niet zichtbaren, k. Tji Bingbin), negen paal ver, over nagenoech-effen terrein. Het landschap verschilt niet veel van hetgeen ik gisteren en eergisteren te-zien-kreeg. Weinich-ofgeen bevolking; een enkele saoeng lioema ${ }^{1}$ hier-en-daar uitgezonderd, tusschen Tji Kĕsik en Soedimanik geen-andere kampoengs te zien dan Kĕndal op twee, Bĕnjing hidĕng op vier, paal afstands van Tji Kĕsik, benevens de bovengenoemde k. Tji Bingbin, waarvan enkel de gardoe, Tji Soeakan geheeteu, zichtbaar is. Tusschen Kĕndal en Tji Kĕsik enkel kleine riviertjens, de Tji Kajang, de Tji Ririgi, de Tji Katilěng, en een menichte anderen, waarvan $\mathrm{ik}$ het der moeite niet waard acht, de namen op-te-schrijven. Uitzicht volstrekt-niet; men rijdt onophoudelijk tusschen glagah en kreupelhout door; en waar een enkele maal een open plekjen is, vertoont zich, ook in het verschiet, aan weêrskanten niets dan bosch en nochmaals bosch met zijn vale, doffe, neêrdrukkende, eenvormige kleur. Maar tóch is er verschil. We ontmoeten v e el-minder glagah, veel-meer kreupelbosch; en met name overal een rijken overvloed van in het wild groeijende bamboe, die zich op sommige plaatsen allersierlijkst over den weg welft, en op een minder-regenachtigen dag, als ze minder zwaarmoedig neêrhing, stellig een alleraangenaamsten indruk zou maken. Ik schijn hier in het land van de bamboe; ook even-vóor Tji Kěsik zag ik gisteren, op kleinen afstand van ons pad, een allerprachtigst bamboe-bosch. Jammer, dat zooveel kapitaal onbenut moet blijven; want voor de behoeften der dungezaaide bevolking groeit er oneindig-veel-te-veel, en aau afvoer naar elders is, bij de enorme afstanden en het volslagen gemis van waterwegen, geen denken. Tusschen Kĕndal en Bĕnjing hiděng gingen we twee, vrij-waterrijke, rivieren over, de Tji Garoepak en de Tji Teras, tusschen Bĕnjing hidĕng en gardoe Tji Soeakan twee soortgelijke, de Tji Lĕngsir en de Tji Soeakan (welke laatste we doorwaden moeten, daar de brug op het instorten stond.) Tusschen gardoe Tji Soeakan en Soedimanik wederom twee soortgelijke, de Tji Djoedjoeng en (op twee paal van de hoofdplaats) de Tji Balioeng. Al die

1 Een klein gebouwtje voor tijdelijk gebruik in de hoema opgeslagen. M. 
rivieren wateren, volgens hetgeen me gezegd werd, in de Tji Binoeagan uit. Ze zijn allen met stevige, hooge, houten bruggen voorzien; hetgeen niet wechueemt, zeî me de demang, dat gedurig in de regenmouson die bruggen wechspoelen. Ik kan me dat begrijpen, als ik naga, met hoeveel onstuimigheid ze ook-nu-reeds, na een regen van éen nacht, hun troebele wateren voortstuwden. Tusschen gardoe Tji Soeakan en Soedimanik (een afstand van noch ruim vier paal) werd de weg veel breeder, maar de grond weêr veel-golvender en vol wadas, welk-laatste trouwens wel te zien was aan de dwergachtige gedaante en de geele bladen van de pinangs en andere vruchtboomen, die men gepoogd had, langs den weg te planten. Hier stonden ook weêr een eind lang djatiboomen (althans, kromhouten die ze reprezenteeren moesten.) Dit herimnert me aan een gouvernements-koffiaanplant, dien ik tusschen Kĕndal en Bĕnjing Hidĕng zag, en waarvan de dadaps of schaduwboomen uitmuntend stoudeu; jamıner maar, dat de koffiheesters, zoo-tezeggen allen, dood waren. Doch laat ik niet afdwalen. Links van ons was hier weêr veel glagah, waaruit we eenmaal, vlak bij ons, vier boschhoenders of kasintoe's tegelijk zagen opvliegen. Op een zonnigen dag moet het hier brandend-heet zijn; nu hadden we echter niet bepaald overlast van de hitte, en waren in zooverre blijde, dat we wat minder in den lommer reden, dan op het éerste gedeelte van onzen tocht. Rechts was niets te zien als onafgebroken bosch, waarmeê ook de lang-uitgestrekte, in de verte zichtbare, bergrug van den Goenoeng Kendeng, in de richting van het (volgens den demang nu opgebrokene) Djoengkoelan, bedekt is. Sporen van bebouwing waren bijna-niet te ontdekken; hier-en-daar een stuk afgebrand kreupelhout, een enkele hoema, nu met djagong en katèla beplant, twee, drie saoengs, - een op bevel door den demang aangelegde proef of modèltuin (waarin ik echter, op een bouw uitgestrektheid, niets dan djagong opmerkte), - verder zag ik niets. De hoema's van Soedimanik (sawahs en ook tipars heeft men daar niet) liggen zeker in een andere richting.

Gedurende de twee laatste palen van onzen tocht klaarde het gelukkig een beetjen op, zoodat we niet druipnat, maar alleen in een vergevorderden staat van klamheid Soedimanik naderden. Ik zag hier veel katoenboomen (randoe's); evenals ik die, reeds even-door Tji Kĕsik, gezien had. Ik vroeg aan den demang of er hier veel katoen geplant wordt. Het antwoord 
was, dat er hier veel werk gemaakt wordt, zoowel van de kapas (de éenjarige katoenheester) als van de randoe; en dat in het saizoen de menschen van het noorden in groote menichte hierheen komen om het artikel op-te-koopen. Het is zeer te wenschen, dat de verdere ontwikkeling van deze bron van welvaart door niets worde tegengewerkt. Voor het huis van den demang zag ik een gomelastiek-boom met zijn groot, prachtig, glanzig, zacht-donkergroen blad. Hij verzekerde, dat ze zich niet laten voortteelen. Hij had; op last natuurlijk (welk inlander doet zoo-iets uit eigen beweging?) duizende stekken geplant; ze waren in den beginne perfect aangeslagen; maar, nadat ze op zekere hoogte gekomen waren, sukcessievelijk gestorven. Kan het niet aan den grond liggen? of heeft men ze ook overgeplant, en dat zonder de noodige zorg? Ik zou, als ik hier kontroleur was, de proef onder mijn eigen oog laten herhalen.....

Alleen moet ik noch-even (al kan je het niet apprecieeren) een klein proefjen geven, hoe uiterst-omzichtig ik zijn moet in het aannemen van de inlichtingen die men me omtrent de taal geeft of geven wil. Ik vroeg onderweg aan den demang, of glagah ook-hier glagah heette. "Trada, toean, lěwěng sallja" Mijn vraag was een strikvraag, zijn antwoord een grove onwaarheid. Ik zeg: "kaloe begitoe, demang, glagah di sini dikata barangkali lěwěng, dan lěwěng glagah?" En wat antwoordt me de kerel met een impertubabel gezicht? "Saja, toean." Gelukkig, dat ik wantrouweud ben uitgevallen; daardoor ben ik, malgré moi, niet in de mogelijkheid om me zoo te laten beet nemen als de Wilde met zijn batoe sempoer en bengbèrètèja.

28 Juli. De ondergeteekende heeft gisteren-avond het spreekwoord te schande gemaakt, dat de natuur sterker dan de leer is; zijn natuur dwong om slaap, maar zijn leer is om hier, waar ik naar alle menschelijke berekening nooit teruchkom, elke minuut te benuttigen, en die leer heeft getriomfeerd. Onwillekeurig ben ik, op de kanapé liggende, met de talrijke bedienden over het Soendaneesch gaan praten; welhaast kwam de demang (naijverig om zelf de noodige inlichtingen te geven) opdagen; ik riep mijn schrijver: en zie! tot over twaalven was ik met het meeste genoegen, en zonder eenig spoor van vermoeijenis meer te voelen, bezig om met de vergaderde 
gemeente een gedeelte van den letter $s$ uit Rigg's woordenboek te behandelen..... Dat doorloopen van Rigg is in-zoo-ver doeltreffender dan het voorlezen van een tembang, daar zooals de schrandere Masroen terecht en met groote verontwaardiging opmerkte, die djaro's bijna-zonder uitzondering "loetoeroel moending baè" (de buffels navolgen), en op zoo'n verhaaltjen dat men hun voorleest, maar altijd ja en amen zeggen.....

Van morgen van achten tot twaalven voortzetting der behandeling van Rigg met een vrijj-talrijk personeel, waaronder een volbloed Buitenzorger, hier echter door een vijfentwintig-jarig verblijf "eingebürgert", Mas Nata Joeda (wiens zuster met den overleden regent van Tjiringin getrouwd is geweest, en die thans de rol van onderwijzer vervult in de, sints een jaar op bevel uit de nagri gestıchte, "kostschool " voor zoneu van hoofden, waar het Arabiesche eu Hollandsche letterschrift benevens het rekenen geleerd wordt; waar oorspronkelijk acht leerlingen waren, nú noch vijf; en die zoo-goed verzorgd wordt, dat éenemaal papier en inkt hem is toegezonden, en nu niet meer.) Met de scholen gaat het hier als met de vruchtboomen van langs den weg, die geplant worden om aan het ontfangen bevel te voldoen, en waar men verder niet-meer naar omkijkt. Wat is hier veel heil te wachten van die Europische "natuurlijke toestanden ", waarbij alles aankomt en ook alles gebazeerd is, op de zelfwerksaamheid van het individu.....

De kampoeng, klein maar op het oog niet onwelvarend, vol oude en ook jonge klapperboomen, is meest langs den weg naar Patoedja gebouwd, in de nabijheid van de Tji Soedimanik en de Tji Kalong, wier wadasbedding nu bijna droog lag, maar wier, zeker twintig voet hooge bruggen in den regenmoesou toch gedurig worden wechgeslagen. Ik zag op kleinen afstand de balè (om haar geringheid en onooglijkheid niet mesigil genoemd), die ook-hier, waar maar twintig orang koewat ${ }^{1}$ zijn, natuurlijk niet ontbrak. Ik was in de gelegenheid, om op-te merken, hoe ongelooflijk-slecht de grond hier is; niets dan wadas, bedekt met een uiterst-duune humuslaag. Verwonderlijk, dat er allerlei vruchthout, randoe als anderzins, noch zoo-welig groeijen wil. In den tuin van den demang stonden twee kakaoboompjens, gekweekt van pitten, die hij uit de nagri gekregen had, zeer tierig en vol vruchten. Zoo men de bereiding

\footnotetext{
1 Heerendienstpligtigen.
} 
verstond, zou de kakaokultuur hier misschien noch een winstgevend iets kunnen worden. Peper en sirih, hier-en-daar ook een enkele koffiheester (waarschijnlijk het droevig overschot van aanplant van pagerkoffi in de kampoengs "op hoog bevel", zooals men op de komedie-affiches leest, ook-wanneer er een treurspel wordt opgevoerd), troffen onder het voortloopen mịn oog. In den pasanggrahan teruchkomende, vroeg ik naar de reden, dat de bangbara's 1 noch uiet bezig waren om de balken van het gebouw (dat toch al twee maanden staat) te vernielen; ik vernam, dat hij enkel kihiang-hout, een uitmuntende houtsoort, had gebruikt. Een navolgenswaardig voorbeeld; een handelwijs waardoor veel nuttelooze arbeid bespaard wordt. Straks om half acht voortzetting der behandeling van Rigg. Ik was, toen bij twaalven de sessie was afgeloopen, van het visschen en vragen en luisteren te-vermoeid om gisteren avond hier noch bij-te-voegen, dat het me gelukt was, de letters $s$ en $a$ met mijn "inlandsche helpers" (waarvan de meesten, ook de demang, wel zeer rustig zaten te slapen, maar enkelen, vooral de pangōeloe en de meester, me zeer "uitgeslapen" bleken te zijn), af-te-handelen.

29 Juli. Om acht uur vertrekken we van Soedimanik naar Patoedja. De zon schijnt helder aan een onbewolkten hemel, iets wat we, niet-alléén zien, maar op ons veelal-schaduwloos pad ook voelen. De weg loopt, tout comme à l'ordinaire, gedeeltelijk tusschen glagah, gedeeltelijk tusschen kreupelhout, met opgaande boomen er tusschen, door. Op een paal of drie afstands van Soedimanik is wat Gouvernements-koffi- en djatiaanplant, die om het treurigst staan, de djati misschien door verwaarloozing en te-wijd uiteeuplanten, want de kleur van den stam is goed en het voorkomen van de bladen gezond; de koffi waarschijnlijk doordien de grond niet deugt, want een afgeschreven tuin en een vóor drie jaar nieuw aangelegde (van 6000 boomen) zagen er even ellendig uit. M e n s ch en ontmoetten we er, dicht-bij Soedimanik, twee; verder niemand. Kampoengs geen-enkele, tot-aan zee toe; alleen de twee gardoe's Tji Njoeroep, 4 paal, en Toengtoeroenan, 8 paal van des demangs zetel, die door de bevolking van den (niet zichtbaren, maar op een paal of vijf afstand van Soedimanik liggenden) $k$. Tji Njoeroep bezet worden. Weêr een rijke overvloed van bamboe langs den

1 Een soort zwarte bij of tor, die gaten in hout boort. Ml. Koembang. (Jav. Idem?) M. 
weg. Evenzoo weêr een onnoemelijk aantal, bijna niet noemenswaardige riviertjens, die we, na den Tji Soedimanik en den Tji Kalong deels-over deels-doorgaan; de Tji Mahpar, de Tji Kasak, de Tji Djempog, de Tji Haoer, de Tji Bĕrĕm (tusschen paal $\mathrm{l}$ en 4); de Tji Boeloe, de Tji Boentoe, de Tji Moentjang, de Tji Hoerang, de Tji Katoelampa, de Tji Gadok, de Tji Toèk en de Tji Aèrdoea, tusschen paal 4\% en 8 ; alleen de Tjekèkan (tusschen de Katoelampa en de Gadok) was een rivier van een fatsoenlijke breedte, die moet dau ook in de westmoeson vreesselijk kunnen spoken. De wadasbeddingen dezer riviertjens liggen geen van allen in diepe terrein-iuziıkingen; vandaar dan-ook, dat de weg voor een weg in een bergland vlak mag genoemd worden......

Aan de gardoe Toengtoeroenan hielden we stil. De pondok (waar ook twee slaaphokjens, met de grondstoffen voor slaapsteden, waren) is op een verrukkelijk punt gebouwd; hoog, zoodat men een prachtig gezicht op zee heeft, en de zeewind (die b. v. hier te Pathoedja, geheel door de pandan, de zoogenaamde wilde ananas, een hooge heester met sierlijke, purperen, maar helaas! oneetbare vruchten, van welks bladen uitmuntende matten gevlochten worden, en waarvan het nut hetzelfde is als bij ons van de duinhelm, dat er namelijk de zandverstuiving door belet wordt, die, "zeg ik" zou een nutverhandelaar, na, zoo'n langen tusschenzin zeggen, b. v. hier te Patoedja geheel door de pandan wordt opgevangen en tegengehouden) u verkwikkend tegenwaait. Als ik ziek werd, zou ik hier wel een paar maanden voor herstel van gezondheid willen henengaan. De demang vroeg me hier naar Holland, of het niet een groot land was, (waarop ik natuurlijk, met een leugentjen om bestwil, ja antwoordde), en of er enkel-Hollanders woonden, niet vermengd met Javanen (iets wat ik met een geruster geweten bevestigen kon). Ik hoor, dat er geen denken aan is, om tot Djoengkoelan (of liever tot de plek waar het gelegen heeft, want de bevolking is sints-lang verhuisd naar Poelo Panaïtan) te komen; dat hij het dan wel een maand vooruit had moeten weten, om een weg door de bosschen te laten kappen als andersins, dat hij-zelf, ofschoon hier twintig jaar demang, er noch-nooit geweest is. Ik had toch al van het voornemen, om er heen te gaan, afgezien; de moeite zou door het nut van den tocht stellig niet beloond wordeu. $\mathrm{Na}$ een kort oponthoud vervolgden we langs het strand onze reis naar Patoedja. We leggen de drie paal meestal in gestrekten 
draf af. Het smalle strand bestaat meestal uit fijn, geelwit, rul schelpzand, waarin de hoeven van de paarden diep wechzinken. De weêrkaatsing van het zonlicht op de witte branding en het witte oeverzand doet de oogen pijnlijk aan. Het oor wordt moede van "'t eeuwig branden van 't wijd atlantisch meer, dat dondert aan onzen voet," en welks hooge golven nimmer moede schijnen te worden, op de gevaarlijke kustklippen zich te-pletter-te-spatten. Ontmoedigend is het gezicht op dien oneindigen groenen waterplas, welks eentoonigheid door geen enkel zeil verbroken wordt; alleen het, onder Tjilangkahan ressorteerende, eilandjen Tendjil vertoont nevelachtig zijn grenslijn aan de kim. Bij het doorwaden van de monding der Tji Teloeg was ik bijna van mijn paard getuimeld; het was vloed, en er kwam eensklaps zoo'n vervaarlijke golf opzetten, dat ik in-eens tot aan mijn knieën doornat was, en door de kracht, waarmeê dit onverwachte voetbad aankwam, haast het voorbeeld gevolgd had van een der Inlandsche hoofden, die (maar hij, ik beken het eerlijk, omdat zijn paard bang werd), zoo-lang als hij was, in het water terechtkwam. We passeerden Tandjoeng Tjariang, en sloegen welhaast een binnenpad in (de strandweg houdt hier op), dat ons in weinige minuten te Patoedja bracht, een klein, vreedsaam, zeedorpjen. Ik stapte af aan de balè, (de bidplaats in de vastemaand, op plaatsen waar geen mesigit is) een klein huisjen, bestaande uit één vertrek, waar mijn tafel, mijn (inderhaast van bamboe opgeslagen) ledikant, en mijn koffer de beschikbare ruimte nagenoech-geheel vullen. Het is goed dat ik geen "jonge maagd" ben, want de balè (die, bijna aan het eind van de dubbele rij huizen in een overdwarsche richting daartusschen-in gebouwd is) heeft van voren niets, wat naar een afsluiting zweemt, zelfs geen gordijn; ze is geheel-open, zoodat men zich aan- en uitkleedt ten anschouwe van het gansche Patoedja'sche publiek. De demang vertelde me, dat dit Patoedja eigenlijk maar een tijdelijke verblijfplaats van de bewoners is; dat tegen den tijd van de bewerking der hoema's de mannen allen naar de bergen verhuizen, waar ze hun hoema's gaan aanleggen en een tweeden kampoeng hebben; dat ze tegen den snijtijd door al wat leeft gevolgd worden, en dat d it Patoedja dan leeg blijft staan.... Daarna een wandeling naar de een halve minuut bewesten mijn verblijf gelegen, monding van de Tji Patoedja, wier kalm en kristalhelder water, tot dicht bij zee door donker loof overschaduwd, me aan de Tji Madoer herinnert, en zeer tot een vaartochtjen uitlokt, dat 
echter tot de onmogelijkneden behoort, om de eenvoudige reden dat de menschen zich hier de luxe van praauwtjens niet permitteeren (die ze trouwens op de rivier niet noodig hebben, en op zee, om de woedende, onophoudelijke branding, niet gebruiken kunnen). Vlak-bij is een overvaart (door middel van een èrèlan), waarmeê men op een binnenpad komt, dat naar de k. Toegoe voert.

31 Juli. Zeer vroeg op, om dat ik me van den-af-te-leggen afstand, onder den invloed van de onjuiste inlichtingen der inlanders overdreven voorstellingen heb gevormd. Voor zessen zijn we reeds op weg. Na de Patoedja vlak-aan haar monding doorwaad te hebben (het is vloed, noeroen pasang; en we moeten daartoe den oogenblik van den terugslach der branding afwachten), rijden we voort over een breed, zandig strand, aan de landzijde wederom omzoomd door hooge, dichte pandan. We passeeren onderscheiden rivieren; de Tji Hanojan, de Tji Daon, de Tji Rantjètjèt, maar wier bedding lager ligt dan het strand, zoodat ze, althans in den droogen moeson, niet in zee uitwateren. Langsamerhand, wordt de strandweg alsmaller en smaller, zoodat het kokende schuim van de golven gedurig de hoeven onzer paarden bespat. Verscheiden, in zee vooruitstekende landpunten snijden we af, door binnendoor te gaan; Tandjoeng Rantjètjèt, T. Kakoerantjak, T. Tji Pinang, en noch een paar anderen; maar aan T. Gepokan gekomen, waar het maken van een voetpad onmogelijk was omdat de geheele landpunt uit hooge, steile rots bestaat, en waar tegelijk van strand geen spoor meer te bekennen is, moeten we van onze paarden klimmen, en over scherpe rotspunten, soms tot aan de knieën door de zee waden. Haar water was, stellig door den heftigen golfslag, laauw om te voelen; mijne bloote voeten genoten er van, meer dan van den klipgrond. Ik vernam bij deze gelegenheid (wat zich trouwens van zelf laat begrijpen), dat in de westmoeson er geen denken aan is, om hier door-tekomen; dat men dan, om (van Soedimanik uit) Tji Kawoeng te bereiken, binnendoor, den weg naar Tji Manggoe opmoet, tot aan Tji Tangkil. - $\mathrm{Na}$ de moeijelijke passage van $\mathrm{T}$. Gepokan en de, onmiddelijk daarop volgende, doorwading van den breeden, waterrijken, Tji Aèr djeroeh, gaan we een eind binnendoor; maar komen welhaast weêr op het strand uit, waar we in de Tji Soerianĕn, de Tji Aèr Tjegog, en de Tji Boeha, de éerste riviereu passeeren (na de Tji Patoedja altijd) die eeu 
behoorlijke uitwatering in zee hebben. Onze paarden hebben het een poos zeer zwaar te verautwoorden op eeu, door de zee-zelf gevormde, zeewering, bestaande uit een laag blaauwe keijen, uit de beddingen der rivieren bij bandjirs losgewoeld, en later door de branding weêr op strand geworpen. Vervolgens maken we een geweldigen doorsteek binnendoor, over een terrein dat, begroeid, deels met kort gras, deels met laag kreupelhout, wonder wel gelijkt op een Hollandsch duinpad; en verlaten, als we eindelijk weêr op het, in den regel hier zeer smalle, pad uitkomen, dat niet weêr, voordat we, na doorwading van den Tji Kalèdjètan, in de gardoe vau dien naam zijn aangekomen (18 paal, gelijk men beweert, maar ik niet gelooven kan, van Patoedja). Op dit laatste gedeelte van onzen weg langs het zuiderstrand hadden we, éerst een poos lang hoog bosch inplaats-van pandan aan onze rechterhand (het was, waar de Tji Mokah parallel met den hier weêr breeden, zeeoever voortloopt), daarna echte duinen; hooge zandverheftingen, van boven tot onderen mei pandan begroeid, en die een bijna-onweêrstaanbaren hang naar andere duinen bij me opwekten.

De pondok te gardoe Tji Kalèdjètan (ressorteerende onder den kampoeng Tji Boenar) ligt in den oostmoeson even-aangenaam als die te gardoe Toengtoeroenan (aan den weg van Soedimanik naar Patoedja); in den wéstmoeson echter, wanneer het zeewater, door den westewind voortgezweept, er binnenspat, moet het er minder aangenaam zijn. $\mathrm{Na}$ in die pondok haastig gegeten te hebben, sloegen we landwaarts in, ten einde in een noordwestelijke richting onzen tocht naar Tji Kawoeng voort-tezetten. Het grootste gedeelte van den tijd werd besteed aan het overtrekken van het, in laagte met zijn lengte wedijverende Kendeng-gebergte, waarop echter tot mijn verbazing geen spoor van zwaar geboomte meer te bekennen was; de bekleeding bestaat uitsluitend uit galagah en jong opgaand hout. Het schijnt wel, dat men de bosschen totaal vernield heeft voor het aanleggen van hoema's (van welke laatsten ik, tusschen twee haakjens, in het voorbijrijden hoorde, dat hier geen blijvend eigendomsrecht bestaat, ook al ompaggert men ze). Nadat we letterlijk ongemerkt (zoo-onmerkbaar is zijn glooijing) den G. Kendeng waren afgedaald, kwamen we in een water-en boschrijke streek, waar de grond (zooals de demang zeide, hier niet met wadas bezwangerd, maar met zand vermengd) kennelijk hoe langer hoe beter werd. Ik kwam langs een aanplant van goe- 
vernemęnts-koffi, dichtbij Tji Kawoeng, die (voor Zuidbantam altijd) heel redelijk stond, ofschoon ze noch geheel volgens het oude systeem voor het zonlicht was afgesloten. Ook-hier groeit in het wild een schat van bamboe en rotan, welk-laatste echter door de bevolking geëxploiteerd schijnt te worden; althans, een hadji uit het noorden (ik meen van $\mathrm{Tji}$ Loerah) is bezig, hier drie eigen praauwen met rotan te beladen, die hij van haar heeft opgekocht. We doorwaadden achtereenvolgens de Tji Kawoeng, de Tji Pinangboeloe, en de Tji Tamandjaja (om van allerlei kleine waterlooze of bijna-waterlooze, spruitjens niet te spreken), en waren uu in een oogenblik te Tji Kawoeng, waar ik aan de pondok afstapte.

Deze pondok, bestaande uit een lange, aan alle kanten opene, pendopo of galerij. met een slaaphokjen zonder licht of lucht aan weêrskanten van haar zuidelijk gedeelte, staat met haar front naar het noorden, op hoogstens vijf-en-twintig passen afstands van straat Soenda.

Het gezicht, dat men uit haar heeft, op de plek waar ik zit te schrijven, is zeer schoon. Zuidwestelijk het lang nitgerekte en tegelijk hooge Pajong-gebergte, geheel geïzoleerd boven den veel-lager liggenden omtrek uitstekende, en daardoor te sterker uitkomende. Vlak voor zich het eiland Handělěm en het eiland Boboko (eigenlijk twee Handělĕms, een Handělĕm pinggir en een Handělĕm tengah.) Ver réchts vóor die eilandjes vooruitspringende, de vaste wal van Bantam, een landpunt vormende, die Tandjoeng Alang alang heet. Daaráchter een hooge berg. rug zichtbaar, die men me zegt dat op het Prinseneiland t'huis behoort (welk Prinseneiland, naar een djaro, die niet dom schijnt, en die er meer-dan-eens geweest is, me verzekerde, zoet water in overvloed bevat). Rechts is in de verte, op kleinen afstand van de kust, het eilandtjen Badoel zichtbaar; dat zich als een bolronde groene massa hoog boven de oppervlakte der zee verheft. En nevelig vertoonen zich in een verwijderd verschiet de omtrekken van het spitstoeloopende Krakatoea (of, zooals het hier heet, Rakata), waar Gronovius rust in zijn eenzaam, onbekend graf. Op de kalme, spiegelgladde wateren van straat Soenda, wier zacht gekabbel aangenaam is om te hooren, hier-en-daar een van die ranke bootjens (men zou ze best met onze gieken kunnen vergelijken), waarmeê de inlander zich zoo-stout durft wagen, tot ver in zee, en aan de kim een paar zwarte stippen, gelijk ik ze van het Scheveniugsche strand 
af, zoo-dikwijls gezien heb; zeilen, wier gezicht op dien wijden waterplas, iemand goed aan het hart doet. Ten overvloede vlakbezuiden mijn pendopo de monding van de Tji Tamandjaja, gezellig gestoffeerd met de drie praauwen, waarin de bovengenoemde hadji zijn rotan kwam laden. Het liefelijk, vreedsaam en schilderachtig geheel, deed me waarlijk voor een oogerblik mijn dolle kiespijn vergeten.....

1 Augustus..... Mijn hart was goed, om een uitstapjen naar Handělĕm te maken, waar men van hier in een roeibootjen gemakkelijk' eu spoedig (uiterlijk twee uur; ik-voor-mij geloof: eerder) komen kan. Maar er een heelen dag aanknoopen, in het belang van mijn taalstudies, wil ik niet; ik moet mezelf grenzen stellen, en voor loutere pleiziertochtjens heb ik hier om de zuid geen tịjd meer beschikbaar; ik ga dus maar weêr aan mijn plichtwerk, en zet van half-acht tot twaalven de behandeling van Rigg voort. We vorderen tot Gergardji. Daarna noch een poosjen napraten met den demang, die me onder-anderen vertelt, dat er in het heele demangschap Tji Balioeng maar drie hadji's zijn.....

2 Augustus. Daar onze weg, om naar Soemoer te komen gedeeltelijk over het strand loopt, moeten we de ebbe afwachten; het is-uit-dien-hoofde eerst on acht uur, dat onze kavalkade (bestaande uit veertien personen te paard, en negentien, met bagaadje en andere benoodigdheden, te voet) zich in beweging stelt. Als al die menschen betaald moeten worden; met andere woorden: als men de heerendiensten afschaft; is aan reizen in het eigenlijkgezegde binnenland geen denken meer. We gaan met prachtigen zonneschijn van Tji Kawoeng, die echter wel-eens hinderlijk had kunnen worden, als we niet meestal in den lommer van hooge boomen of vlak-langs zee gereden hadden. Ik durf een tochtjen van Tji Kawoeng naar Soemoer aan iederen toerist aanbevelen. De weg is een donker-beschaduwd, schilderachtig boschpad, dat zich telkens langs den zeekant heenslingert, en zich in een smal, door de vreedsaam-kabbelende wateren van straat Soenda bespoeld, door de zware stammen en het prachtige loof van reusachtige njamploengs (die zich neêrbuigen, als wilden ze de golven kussen) overwelfd strandpad verandert, van waar men op de omliggende eilanden en Sumatra's hooge bergen een verrukkelijk-schoon gezicht heeft. Hoeveel moeite de bevolking ook gedaan heeft om, ten behoeve van haar hoema's (een soort van drooge rijstvelden) de bosschen te vermielen; hoe-dikwijls 
men dan-ook, dien-ten-gevolge, aan weêrskanten van den weg niets dan alang-alang of jong kreupelhout ziet; op vele plaatsen met de halfverbrande tronken van reusachtige boomen, als een aandoenlijk gedenkteeken van vernield natuurschoon; - verreweg het grootste gedeelte van den tocht gaat men door maagdelijke bosschen met hun sierlijke lianen en hun vorstelijke kiara's en hun tooverachtige lichtspelingen, om zich bij tusschenpoozen weêr te verkwikken aan de koele zeelucht en de liefelijkste zeegezichten. We begonnen met een grooten doorsteek binnen door te maken, terwijl we achtereenvolgens de Tji Boentoe, de Tji Pinang ading, de Tji Binoea en de Tji Saät doorwaadden; gingen daarop een eind, deels langs het strand, deels (waar de neêrhangende njamploengs het eigenlijk-gezegde strand versperden) door het water heen; daarop weêr landwaarts in, de Tji Boeroeloe, de Tji Gorondong, de Tji Pining door; en hielden stil te Tji Pining, een kleine ampihan van den kampoeng Tji Tangkil. Rechts van ons hadden we, op dit eerste gedeelte van onzen tocht, den hoogen Goenoeng Honjè met zijn ondoordringbare bosschen; gelijk we láter het gezicht kregen op de, kennelijk soortgelijke, bergen van Tjamara. Het schijnt hier een waar tijgerland; althans een eenzaam huisjen, dat we tusschen de Tji Gorondong en de Tji Pining voorbijkwamen, rustte op palen, die stellig tien voet boven den grond uitstaken. Ik had hier-ergens noch gelegenheid, om de ellendige onverschilligheid van den inlander op-te-merken; een eindtjen weg, waar jonge klappers langs geplant waren, en dat men (ongetwijfeld te mijuer eer) van onkruid had moeten zuiveren, had men gemakshalve, met jonge klappers en al, maar a fgebrand, enkel om zich de moeite te besparen, van vijf minuten lang zijn arit te moeten gebruiken. - Van Tji Pining (vijf paal ongeveer van Tji Kawoeng) tot Soemoer ontmoetten we (met uitzondering van een kleine ampihan van k. Tji Manggoe, een paal bezuideu Soemoer) geen spoor van bewoning meer. In de natuur, die ons omringde, geen verschil, behalve dat we hier van-tijd-tot-tijd rijzen en dalen moesten (op de wegen in het Tji Balioengsche wezenlijk een zeldzaamheid) - dat we noch-meer eigenlijk-gezegd "oorspronkelijk bosch" ontmoetten, — en dat, betrekkelijk, het aantal rivieren minder werd (we doorwaadden enkel-noch de Tji Poenaga, de Tji Haoer, de Tji Honjè, de Tji Awi lětik en gedè, en driemaal den, blijkbaar geweldig-kronkelenden, Tji Soemoer, of liever tweemaal, want de derde maal lag er 
een brug.) Even-vóor deu bovengenoemden ampihan van Tji Manggoe liep met ons pad de eigenlịke weg vau Soedimanik naar Soemoer samen, die er ook zeer uitlokkend uitzag, althans voor iemand die, zooals ik, van zulke donkere boschpaden houdt. Bij dien ampihan zag ik voor-het-eerst een Goevernementspeperaanplant, als het er overal zoo-ellendig meê geschapen staat, zal men verstandig doen met de peperkultuur ook-hier maar zoo-spoedig-mogelijk in-te-trekken..... Om éen uur zoowat kwamen we aan de plaats onzer bestemming..... De pondok is geheel volgens het systeem van die te Tji Kawoeng, en even-dicht aan de zeeoever gebouwd, maar met het front naar het westen, en met sierlijke klapperboomen er voor. Op drie minuten afstands ligt het eilandjen Soemoer, van den vasten wal door een zandplaat afgescheiden, die alleen tijdens den vloed onderloopt; bij onze ankomst lag ze geheel-droog. In een zelfde lijn met Poeloe Soemoer, en daarvan niet-meer dan een steenworp verwijderd, liggen, rechts het eilandjen Demang, links het eilandjen Oar (van-uit mijn pondok gerekend).......

's Avonds aan Rigg, we avanceren tot jogjog.

3 Augustus. Alweêr den heelen morgeu lang, van hetzelfde laken een pak. We vorderen tot katunchar (lees: katoentjar). Als het zoo-voortgaat, krijg ik Rigg misschien noch uit in het Tjiringinsche.... Ik mak van de eb gebruik, om met mijn onderhoorigen en eenige geleiders een wandeling naar en over het eilandjen Soemoer te doen. Ik zie daar voor-het-eerst het beroemde Marabou-hout, dat hier, evenals op ál de naburige eilandjens groeit; kolossale stammen net reusachtige wortels, reusachtig-dik en reusachtig-lang. Ik verneem dat er geen twintig boomen meer overig zijn, want dat sints jaren van heinde en ver men er is komen kappen, en dat er geen jonge stekken uit den grond opslaan. Van den westelijken zoom van het eilandtjen zien we negen groote driemasters door straat Soenda zeilen. Van dáar zie ik ook dat aan den vasten wal mijn oog me bedrogen heeft; dat wel Oemang, maar niet Oar, in éene lijn met Soemoer ligt; dat Oar een heel eind in een westelijke richting vooruitspringt. De Tjiringinsche praauw, die gisteren bezig was rotan te laden (ook-hier groeit in de naburige bosschen een schat van bamboe en rotan in het wild; gisteren passeerden we onder-anderen een terrein dat er geheel meê bedekt was; en er wordt dan-ook, vooral in rotan, vrijwat handel gedreven) is noch niet verzeild. Bij een ander schuitjen, 
"van de plaats" zooals men het noemt, zie ik van die tjangkok te droogen liggen, waar de oppasser van den demang gisteren in een half uur tijds vier kranjangs vol van ving, en die men zegt dat bij de rijst zoo-lekker smaakt. Het is een klein, fijn vischjen, niet grooter dan de sardines; ik ben overtuigd dat ze déze-laatsten in Indië zouden vervangen, als men ze maar wist te bereiden. We hebben op den teruchtocht te kampen met vervaarlijke val-of rukwinden, die den heelen middag al heerschen; ze komen natuurlijk uit het Oosten, maar al kwamen ze uit het Westen, met andere wordeu ook in den Westmoeson, zou Soemoer, geloof ik, geen last hebben van het opstuwende zeewater. Het ligt geheel in een baai, gevormd door Tandjoeng Soemoer (zuidelijk) en Tandjoeng Lěsoeng (noordelijk); en die, zeer ondiepe, geheel doorwaadbare en dikwijls droogloopende baai is aan den westkant volkomen gedekt door de eilandjeus Oar, Soemoer en Oemang. Als een merkwaardige zeldzaamheid teeken ik hier noch aan, dat hier te Soemoer een vijttal Palèmbangers wonen, die landbouwers zijn. Aan zee, in de nabijheid van mijn pondok, staat een gomelastiek-stek, die schijnt te groeijen; maar als men overal zulke kromme en oude stukken tak geplant heeft, verwondert het me niet, dat er van den heelen aanplant niets terecht gekomen is.

$\mathrm{Na}$ den eten, tot laat in den nacht, voortzetting der behandeling van Rigg. We vorderen tot Lakoe. Ik moet me schor schreeuwen, om me boven het geloei van den wind uit verstaanbaar te maken.

4. Augustus. Aanvaarding van den teruchtocht uit het Tji Balioengsche. We gaan een eindtjen weêr, eerst langs zoo'n schilderachtig boschpad, daarna over een door njamploengs overwelfden strandweg, tot-aan de Tji Sï̈h. Na dien doorwaad te hebben, krijgen we vast, glad en breed, maar zonder boombekleeding van eenige beteekenis, en daardoor eentoonig strand, slechts een enkele maal (benoorden de grensscheiding) afgewisseld door liefelijk en lommerrijk boschaadje, waar ons pad zich doorheeu kronkelt om welhaast weêr aan strand uit-te-komen, tot den, op vijf minuten afstands van de zee liggenden kampoeng Tjamara toe. De heftige wind van gisteren duurt noch-altijd voort; voor mijn breedgeranden en bandeloozen hoed is hij zeer lastig, maar voor het afbrandingsproces, dat de hoema's dezer dagen ondergaan moeten, allergewenschtst; hij heet dan ook in de waudeling de "afgebeden wind" (angin salatan). Ons pad, dat, 
de richting van het stand volgende, van Soemoer tot-aan de Tji Sïh bijna-pal-oostelijk geloopen had, buigt zich vandaar-af tot Tjamara toe in een noordelijke richting om. Aan de grensscheiding van het Tji Balioengsche en Panimbangsche, de monding van de breede, diepe, zich in twee armen splitsende, Tji Djaralang, die we met een èrètan overgaan, vervaardigd opdat we niet tot aan de borst toe door het water zouden behoeven te waden, verwelkomt me de mantri van Panimbang met gevolg, door gehurkt de samgevouwen handen in aanraking met mijn been te brengen....

Van Tjamara gaan we in een zuidoostelijke richting landwaarts in. Voor ons uit niets dan bosch en bergen. We rijden tusschen nieuw-aangelegde sawah door (de eerste die ik weêr zag sints onze aankomst te Moendjoel), waarvoor de bevolking van het uaburige Tjamara bezig is, zonder eenige hulp eene waterleiding, die we eveneens langs komen, van uit de Tji Tjamara te graven; doorwaden tweemaal deze laatste rivier, wier bijna-drooge bedding me, met den mantri, voor het welslagen dezer energieke onderneming vreezen doet; en krijgen nu weer zoo'n echt, onophoudelijk rijzend en dalend bergpad, als men in Lebak aantreft.

Op een hooge helling, even-nadat we de Tji Tjamara waren doorgegaan, zagen we aan onze rechterhand, in een rechte lijn met het punt waar we ons bevonden (zóo sterk buigt hier de weg zich zuidoostwaarts), Soemoer met zijn eilandjens, bespoeld door de wateren van Straat Soenda, waarir het zonlicht zich vrolijk weêrspiegelde. Steeds rijzende en dalende, soms langs vervaarlijk-lange en vrij-steile hellingen, passeerden we achtereenvolgens allerlei kleine spruitjens, lorah Mareng, lorah Poetak, lorah Waroe, lorah Kadoe, en de Tji Gĕlis; even-vóor lorah Mareng, is een kleine, maar steile, moeijelijke daling langs afgebrokkelden en door welwater glibberigen wadas, waar mijn paard niet afdurft, zoodat ik moet afstijgen, ten-einde me voor een mogelijk ongeluk te vrijwaren. We rijden, gedeeltelijk tus schen dicht ineengegroeid kreupelhout, soms-ook tusschen alangalang, maar meestal tusschen hoog bosch door. Geen kampoeng is aan den gezichteinder te bespeuren in dit woeste, vale kleurlooze bergland, waar het dan-ook wemelt, zoo als men zegt, van tịgers en rhinocerossen. Aan de oostzijde van de Tji Gĕlis gekomen, verlaten we, de tot-dusver gevolgde, zuidoostelijke, richting, en slaan links, dat wil zeggen, oostwaarts, af; op een 
punt, waar de weg een gaffel vormt, en rechtdoor, zooals men me zegt, naar zekere kampoeng Karang Bolong voert. Welhaast wenden we ons noordoostelijk, en komen op een plek, waar we links, op eenigen afstand, Straat Soenda wederom, dit maal met het eilandjen Haliwoengĕn, aan onze voeten zien liggen. We doorwaden de smalle lorah Kèkèha en Tji Lětik, benevens tweemaal de, daar vlak-bij zijnde, breedere Tji Pipisan, en passeeren die rivier vervolgens op een punt, waar ze allerschilderachtigst, ongeveer in den vorm van een halve cirkel, een soort van schiereilandjen besproeit, weiks welig-groenend geboomte zijn zachte schaduwen werpt op haar kristalheldere wateren, die in hun steenbedding liefelijk voortruischen. We reden den kampoeng Sitoe door, en vervolgens de lorah Tegal, die haar naam niet ten-onrechte draagt, want van-nu-af slingert de weg zich meestal, voorzoover hij niet tusschen gewezen hoema's heenloopt, door groene hier-en-daar met geboomte beplante, tegalvelden. Aan een punt gekomen, waar rechtuit een weg naar den kampoeng Tji Serrěhĕn loopt, sloegen wij rechts (zuidelijk) af, om onzen weg naar Tji Sěkět te vervolgen. We komen door Katoembiri, een ampihan van den k. Sitoe (wel te onderscheiden van den, in de nabijheid gelegen, k. Katoembiri); doorwaden de, aan dien ampihan zoomende, Tji Sěkět, en wenden ons nu in een oostnoordoostelijke richting; welhaast arriveeren we nu te Tji Sěkět. De k. Tji Sěkět maakt weêr, door het kolossale en soliede zijner huizen, zijn rijken aanplant van klappers en andere vruchtboomen, en het welgekleede en tevreden uitzicht zijner bewoners, den indruk op me, dien (zonder eenige uitzondering) al de dorpen in het Tjiringinsche op me gemaakt hebben, dat hier, zoo-al geen rijkdom, dan toch wezenlijke welvaart heerscht; dat hier geen overmatige knevelarij van Hoofden moet gevoeld worden. Het dorp ligt nagenoech op een eiland, gevormd door de (in den oostmoeson bijna-waterlooze) Tji Sěkět en Tji Pětěj, die zich benoorden de plaats vereenigen; de eerste van het westen, de ander van het oosten daarhenen samenvloeijend. Er is geen balè, maar een vormelijke masigit, waarhenen gisteren-avond, en heden-morgen (ik schrijf dit op Vrijdag) na afloop onzer samenkomst, veel toeloop was; zooals hier ook een pangoeloe is, die huwelijken mag sluiten. De huizen zijn hoog uit den grond gebouwd en zeer ruim; het geraamte bestaat geheel uit hout. Als men bij ons in de Preanger in de distrikten komt, ziet men dat bijna-nergens; hoewel men volgens Masroen zeer verkeerd zou 
doen, daaruit tot mindere welvaart te konkludeeren. De kampoengbewoner ziet er daar, zegt hij, meer voordeel in, om het hout op de hoofdplaatsen tegen duren prijs te verkoopen, dan om het zelf te gebruiken; en dat is zeer aannemelijk. Hier in Zuidbantam is voor het artikel natuurlijk geen débouché te vinden....

5 Augustus. Met geweldige hoofdpijn begin ik om zeven uur onze samenkomst. Het werken valt me zeer zwaar; verlangde ik niet onweêrstaanbaar naar my dear home, ik zou een dag rust nemen. Gelukkig kan ik toch met sukcès tot klokslag van twaalven mijn bespreking van Rigg vervolgen; we avarıceeren tot ngamboel. Tk kom meer en meer tot de overtuiging, dat indien ik tot het bewerken eener uitvoerige kritiek van Rigg, die me wel aanlacht, mocht overgaan - ik zal moeten beginnen met vergeving te vragen voor het veel-te-zoetbloemige van mijn vróeger-uitgesproken oordeel. Het is zeker wel voorhet-eerst van mijn leven, dat ik niet-scherp-genoeg geweest ben....

's Avonds, ouder gewoonte, van zevenen tot twaalven weêr koempoelan, ..... we vorderen tot het woord palè.

6 Augustus. Om vijf uur op en vóor zessen te paard, teneinde van Tji Sěkět naar Perdana, de hoofdplaats van het distrikt Panimbang, te vertrekken. Gelukkig eindelijk eens een weg, waar zich niets anders van zeggen laat dań-dat hij iets zeer langs, zeer vervelends en zeer Zuidbantamsch was..... Een en twee páal van Tji Sěkět passeerden we noch kampoengs, den k. Sěrěhĕn met zijn ampihan Moehara Tji Sĕrěhěn, en den k. Tji Gabig; gedurende dien tijd reden we ook-noch tusschen, met geboomte beplante, tegalvelden door (terwijl we de Tji Sěkět éens, vlak-bij den kampoeng van dien naam, doorwaadden, en éens met een brug overgingen); maar daarna bleven we, altijd voortrijdende in een nagenoech-pal-oostelijke richting, tot-aan den grooten weg van Tjiringin naar Soedimanik toe, tusschen hoog kreupelbosch, een enkele maal (dit was de eenige variatie) afgewisseld door wat galagah. Bevolking en bebouwing hielden nagenoech op, toen we den k. Kalapa Satangkal aan den Tji Mandahan (dien we, even als een poos vroeger, den Tji Bodas op hooge, leuninglooze bamboebruggen overgingen) uit waren. Het beste bewijs daarvan was, dat de dragers van mijn goed, die gedurende de eerste acht paal driemaal verwisseld waren, van Kalapa Satangkal tot k. Tjorodog, zijnde een distantie van tusschen de zes en zeven paal, door geen andere vervangen werden. Het terrein mag niet geakcidenteerd genoemd 3e Volgr. IV. 
worden; de golvingen van den grond zijn wel vele, maar van weinich beteekenis. Daarentegen werd, van de Tji Latak af (een eind aan déze zijde van Kalapa Satangkal) tot Tjorodog toe, de weg buitengemeen-modderig; ik neem dan-ook gaarne de verzekering van den mantri van Perdana voor waarheid aan, dat men er in den regentijd te paard niet door kan komen, en met een praauwtjen den waterweg langs de Tji Latak moet volgen. $\mathrm{Na}$ (op vijf paal afstands van Kalapa Satangkal) den k. Longkrang, en vervolgens Tji Medang en Tjimara, twee onderhoorigheden van Tjorodog, te zijn doorgetrokken, hielden we in laatstgenoemden kampoeng halt.....

Welhaast kwamen we uit op den grooten weg van Tjiringin naar Soedimanik, een breede, kale, sterkgolvende weg zonder de minste beschaduwing, maar reeds door een minder-unheimische meer-bebouwde en bewoonde streek loopende. We sloegen links af, ten-einde in een noord-noordwestelijke richting onzen koers naar Perdana te richten; passeerden achtereenvolgens de gardoe Angsana, den k. Kalapa doea, de (overbrugde) Tji Taradjoe, den k. Pasir Moeroel; en stapten tegen éen uur in de ruime, nette, aan den waterrijken, met praauwen van zijn monding af tot-hier toe bevaarbaren, Tji Liman zeer frisch gelegen pasanggrahan af.

Indien het waar is (wat de patih me van morgen verzekerde) dat ook noch in het distrikt Tjiringin en zelfs in het Pandeglangsche tot Baros toe Soendaneesch wordt gesproken (welk-laạtste wonder wel overeenstemt met het door mij opgemerkte feit, dat ook te Petir, op nagenoech denzelfden afstand van de noordkust liggende als Baros, het Soendaneesch noch de volkstaal is), dan zal het wel "keine Ruh! bei Tag noch Nacht" voor me bl ij ven yooreerst. Maar enfin! ik troost me met de gedachte, dat het "na gedanen arbeid zoet rusten is."

Voor den eten eene kleine wandeling; na den eten "al weêr van voren af aan," aan Rigg. We vorderen tot peled.

7 Augustus. Vervolg van het voorgaande. We avanceeren tot rebon. 


\section{REIS DOOR SOEKAPOERA.}

\section{KORTE REISAANTEEKENINGEN.}

13 Mei. Om 7 uur 's ochtends, onder een stekende zon, van Bandoeng vertrokken. Tandjoeng Sari. Het lange pad, zich slingerend laugs steile, kale wadashellingen aan den éenen, langs het diepe ravijn van de Tji... aan den anderen kant, door een woest landschap, wekt op nieuw mijn bewondering. Evenzoo treft het me op nieuw, dat zelfs het kleinste plekjen, waar water gebracht kan worden, door de nijvere bevolking tot sawah benut wordt. Langsamerhand dalen we, en komen weêr in een vriendelijke, door kampoengs vervrolijkte natuur. Aankomst te Soemedang.... Ik hoor sommige dingen, die me belang inboezemen: b. v. dat in 7 jaar tijds het getal buffels, die geslacht worden in de Preanger, van 7000 tot 15000 is geklommen; dat verleden jaar het zoutverbruik maar-13 kojangs minder is geweest, in weêrwil van een middelmatigen koffioogst, en dat de bevolking, in-plaats-van ruim een millioen, slechts $f 180,000$ voor koffi heeft gekregen; eu dat de Javasuiker het nooit kan of zal uithouden tegen de beetwortel. Ik vergat bijna te noteeren, dat de Regent me onderweg meêdeelde, hoe oudtijds de groote weg niet langs het slangepad liep, maar dwars over de belendende bergen, en hoe Daendels daar in een kadèra ${ }^{1}$ was langs gekomen.

14 Mei. Om 7 uur op reis naar Malangbong langs den, wel rijzenden en dalenden, maar overigens uitmuntend-onderhouden rijweg, die in 1839-40 (Rezidenten konden toen zulke nuttige ondernemingen noch op eigen gezach aanpakken) is aangelegd. De landstreek is alleraanvalligst, een aaneenschakeling van kampoengs en sawahs, overal doorsneden met grootere en kleinere rivieren. Het wemelt op den weg van voetgangers. Tusschen Soemedang en den eersten post (Ganèas) passeeren we o. a. de Tji Pèlès, en (even-voorbij de $\mathrm{k}$. Tji Konèng) het riviertjen van dien naam. Vervolgens de Tji Soedadjaja, en den k. Tjanoekoer, de Tji Tjapar, zó komen we aan den $2^{\mathrm{n}}$ post (Tji Kadoe). Sukcessievelijk passeeren we nu den k. Doestan, de Tji Bajawak,

1 Kadéra is Pozt. en bet. stoel. (?) 
de Tji Honjè en allerlei anderen; zoo bereiken we den derden post (Dermaradja). Daarna o. a. de Tji Moedja, de Tji Manoek (dien we eerst links van ons in witbeschuimde golven zijn troebele wateren zien voortstuwen over de ondiepe bedding, en daarna tweemaal overgaan, éens op een punt waar twee van zijn armen gaffelvormig samenvloeijen; kort-daarop nochmaals), den k. Wado, enz. Waar de vierde post (Tji Lèngkrang) ligt, pretendeer ik niet precies te weten; alleen weet $\mathrm{ik}$, dat het landschap hoelanger hoe-bergachtiger werd; niets dan bergen, zoover het oog reikte, in de grilligste vormen zich de een boven den ander stapelend, meest-allen zonder boombedekking, maar (waarschijnlijk onder den invloed van de westmoeson) met frisch groen bekleed. Na den Tji Karèo te zijn overgegaan, komeu we aau den woesteu, eenzamen, langen, pasir Tji Karèo, waar de tandjakan Tjaè ons overleidt, uiterst-langsaam en landziekig, want pàlen-ver moeten drie span buffels ons voorttrekken. I $k$ amuzeer me met Soendaneesch van koetsier en loopers op-te-vangen en te bespreken. Gelukkig verliest, nadat we eenmaal den top van den heuvel bereikt hebben, de natuur haar woest, verlaten, onherbergzaam uitzicht weêr. Trotsch en stout blijjen ook-hier van alle kanten de, in wolken gehulde, bergtoppen, b. v. van den Goentoer vèr aan den gezichteinder rechts, van den woudrijken Simpaj vlak-vooruit (om er een páar te noemen), den toeschouwer aangrijnzen; maar aan de hellingen van het gebergte hangen halfverscholen tusschen de geliefkoosde bamboeboschjens en klapperboomen, gezellige kampoengs, afgewisseld door sawahs waarop de padi haar goudgeele airen heen-en-weêr-golft of ook-wel noch prijkt met den onvergelijkelijk-schoonen gloed van haar prachtig groen. In snellen draf dalende, bereiken we welhaast den vierden post (k. Tji Soemawana), en bereiken tegen éen uur behouden de nette pasanggrahan te Malangbong (31 paal van Soemadang ruim).... De avond (het gietregent, zoodat ik niet uitkan om de pakemitan 1 te bezien) vliegt om onder het in-ordebrengen van mijn Soendaneesche aanteekeningen, al pratende en konzulteerende met Masroen ${ }^{2}$ en de pasanggrahan-menschen....

15 Mei. Om half zes uit de veeren, om half zeven in den wagen. Naauwelijks zijn we de brug over de Tji Malengbong gepasseerd, of we krijgen waarachtig weêr buffels en houden die palen ver, den heelen Pasir Tji Sèlang over íwelke laatste

1 Zie vroeger.

2 De schrijver, dien K. bij zijn studiën in dienst had. 
rivier links van de heuvelhelling, waarlangs de weg zich heenslingert, zich in de diepte voortkronkelt, aan den voet van welig-groenende sawahs). Dungezaaid zijn hier de kampoengs die we passeeren (ik herinner me enkel k. Tji Pĕnděj), en aan weêrskanten stuit het oog weêr overal op bergen, maar toch is het landschap niet onvriendelijk, want aan de hellingen van die bergen hangen overal sawahs. Bij paal 35 snijden we den ouden weg naar Manondjaja, die door voetgangers, als de naaste, noch vaak gebruikt wordt. Dicht-bij den eersten post (Tji Panas) verandert het uitzicht en vertoont zich in zuidelijke richting niets dan flaauw golvend, bijna vlak, land. Tusschen den eersten en den tweeden post ('Tji Kolè) ligt de groote, blijkbaar welvarende, kampoeng Tji Awi, waar het me frappeert in deze houtarme streek weêr enkele houten huizen te zien, en waar (dat wil zeggen in den $\mathrm{k}$. Panjoesoekan, die er onder ressorteert) een koffipakhuis is. Tusschen den tweeden en den derden post (Tji Bodas) wordt de landstreek weêr hoe-langer hoe-volkrijker; de grond, tot-noch-toe-hoogrood, wordt weêr zwart van kleur; en een keten van sawahs, deels prijkende met padi, deels beplant met tal van tweede gewassen, omzoomt den weg. Rechts zijn nu geen bergen meer te zien; links daarentegen teekent de G. Tjeremaj en de vooral niet-minder-hooge, G. Bongkok, die daarbij lang-uitgerekt is en zich veel-dichterbij bevindt, zich scherp aan den gezichteinder af. We komen o. a. door den grooten k. Redjapolah. Tusschen den derden en den vierden post (Tasik Malaja) ligt de rijke pakemitan Indihiang, door de Tji Pates (waarover een steenen brug ligt) in twee deelen gescheiden, maar stellig twee paal lang. De menschen langs den weg en in de kampoengs zijn over-het-algemeen goed gekleed en ook het enorme vertier op de pasar te Tasik Malaja getuigt dat in deze streken geen gebrek heerscht. Tk.... rijd rechtdoor naar Manondjaja (waar ik echter, daar ik hier een armhartig stel paarden krijg).... niet al-te-vroeg aankom. Het landschap blijft voortdurend vriendelijk, vlak, bebouwd en volkrijk; de weg, belommerd door redelijkgroeijende djatiboomen (gelijk trouwens van Soemadang af, maar minder-geregeld, en noch dikwerf afgewisseld door waroe's), makt een zeer vreedzamen, Europeeschen indruk.

$\mathrm{Ik}$ stap af aan een nieuwgebouwd, zeer goed ingericht, gebouwtjen voor gasten (balè) vóor het huis van den patih. Deze komt me bezoeken, spoedig daarop ook de Regent; beiden zoogaauw, dat ik geen tijd heb om mijn bemodderde broek met 
een schoone te verwisselen. De regent is een man in de kracht van het leven, met heldere oogen in het hoofd; de patih een oud man; beiden komen bijna-zonder gevolg. Ze eten met me. Tegen vijf uur (want het gietregent) zendt de Regent zijn rijtriig, om me te brengen naar zijn, 11 maanden oud, buitenverblijf, $\frac{3}{4}$ paal van de nagri gelegen en den stempel van een zeer goeden bouwsmak dragende. Ik mak kennis met de Raden-ajoe (een zacht, vriendelijk aristokratiesch vrouwtjen) en hun oudste kind, een meisje van 6 à 7 jaar....

16 Mei Wie zijn kleêren liefheeft en weinig geduld te verliezen, durf ik niet aanraden om, als er den vorigen avond regen gevallen is, in een laag open wagentjen van Manondjaja naar Bandjar te rijden. Vooreerst is het eigenlijk geen weg voor rijtuigen, hij heeft zulke enorm-sterke golvingen en hellingen, dat men ieder oogenblik met macht van menschen en touwen naar boven getrokken moet worden....

Ten tweede maakt de begrinding, waarmeê men berig is.... hoe prachtig het kiezelzand uit de Tji Tandoej ook wezen moge, dat de paarden bijna-niet voort kunnen, en het begaan van de scherpe kiezels voor hén een soort van Kévelaarsche bedevaart, voor den reiziger een geduldproef eu gehoorbederf is. En eindelijk, waar de weg noch-niet begrind is, stoof ons de geele, taaije, kleverige modder in zulke vervaarlijke klonten en zoo'n enorme hoeveelheid om de ooren, dat ik voor mij me in een stortregen veiliger zou geacht hebben. Het landschap, waar we doorrijden, is heuvelachtig; doch alleen in de richting van het zuiden vertoonen de heuveltoppen hier-en-daar sporen van boschbedekking. Kampoengs passeeren of zien we weinig of niet; - van sawahs zoo-te-zeggen hier geen spoor; maar de nadagen van den westmoeson, gepaard met de vlijt van den landman (die hier sterk doet aan het planten van tweedegewassen), houdt noch-altijd de tallooze tegals, die zich tot-aan den verren gezichteinder uitstrekken, getooid met een frisch groen gewaad. Geüzoleerd vertoont zich, vóor ons uit, in het verschiet de bolvormige G. Tampa-Omas in het Tjiamissche. $\mathrm{Na}$ den $4^{\text {tea }}$ paal verdwijnen meer-en-meer de sporen van bebouwing; het landschap krijgt een woest en verlaten voorkomen

Op den $1^{\text {sten }}$ post (Kebo bolong) voorzien we het rechter voorwiel, dat wrak begint te worden, en sukkelen voort naar den $2^{\text {den }}$ post (Panaèkan), in den kampoeng van dien naam. Dichtvoorbij dien $2^{\text {den }}$ post zien we voor-het-eerst de Tji Tandoej, 
hier noch smal, zich links op korten afstand van ons pad in zijn diepe bedding voortkronkelen. Het is een uiterst-smalle dalkom, waar zij zich baan door breekt; maar liefelijk is haar aanblik, want de landman heeft haar water aanstonds weêr geutiliseerd on sawahs aan-te-leggen, en daaruit zijn natuurlijk overal kampoengs ontstaan. Om de noord omzoomen hooge bergen, waaronder de boven allen uitstekende G. Tjeremaj, den horizon.

We passeeren, zonder iets van belang te ontmoeten, den $3^{\text {den }}$ post (Tji Maragas), en naderen nu allengs de kleine, maar liefelijke, welig met geboomte en sawahs prijkende, vallei, waar Bandjar in ligt. Met gezwinde pas dalen we daarin af, ook omdat de weg hier, reeds voor lang begrind, steenhard is geworden. Ik stap aan den pasanggrahan af.

17 Mei. Om zeven uur den Tji Tandoej naar Sapoe-angin. Aan boord scherp toeluisteren, en allerlei nieuwe woorden opvangen.... We stappen om 3 uur aan wal. Den avond besteed ik met bespreking van het afgeluisterde, en met de rezultaten daarvan aanvankelijk te noteeren.

18 Mei. Om vijf uur doodmoê uit de veeren, ell om half zes weêr aan boord. De Tji Tandoej, met zijn genoechsaam-onbewoonde oevers, meerendeels begroeid met niets dan vaalkleurige kaso ${ }^{\mathrm{I}}$, en slechts op zeer enkele plaatsen prijkend met opgaand geboomte (dat dan noch, althans aan den Soekapoeraschen kant, slechts een zeer smalle streep of zoom vormt, waarachter zich, volgens de mededeelingen die ik ontfang, enorme moerassen uitstrekken), blijft een treurigen indruk maken; het inneêgegane kampoenghoofd zegt, dat de grond zeer vruchtbaar is, maar dat niemand lust heeft zich zoover van de bewoonde wereld afte-zondereu. - Gelukkig heb ik tot over tweeën werk om miju Soendaneesche aanteekeningen bij-te-werken; ..... tegen half vijf slaan onze booten de smalle, ondiepe, maar tusschen bebouwde akkers (een oaze in deze woestenij) zich voortslingerende Kali Poetjang in, die ons in de nabijheid van den pasanggrahan brengt. 1k mak geen gebruik van de zeer antieke tandoe, die aan de aanlegplaats gereed staat en wandel (ik gis, een halve paal ver) door de welvarende, met de prachtigste vruchtboomen prijkende pakemitan naar de pasanggrahan, die op de aloenaloen staat, op den weg van Kawasèn naar Tjikemboelan. I $\mathrm{k}$ stuur (daar ik zoo graag wat van het kasar - eig. ruw, grof,

1 Volgens Rigg Soendaneesch voor 't bekende glagah. (M.) 
dus gemeen - Javaansch zou weten, dat de bevolking hier spreekt, als ze onder zich is; en daar er voor mij geen denken aan is, om iets te weten te komen van deze menschen, zóoverlegen voor vreemdelingen, dat ze, zelfs als mijn schrijver hun naar de beteekenis van een of ander woord, dat hij hen hoort gebruiken, vraagt, niets dan "tě njaho" 1 mompelen, en wechloopen, zoodra ze hem een potlood in de hand zien nemen om het op-te schrijven) in 's hemels naam, Masroen noch-maar-eens op een outdekkingstocht uit.

19 Mei. In den voorochtend noch-altijd slagregen, zoodat we eerst tegen tien uur kunnen opbreken. De weg, die zich met sterke golvingen langs een. heuvelrug slingert, die men me als den pasir Panerèkèan noemt, is onbeschrijfelijk modderig en glibberig. De sterke inzinkingen van het terrein zijn, waar achtereenvolgens de kleine spruitjens Tji Tjoela Mèga, Tji Empak, Tji Kadoe, en Tji Tanga Wedan zich baan breken. Het terrein is als in Zuid-Bantam, eenzame wildernis, met laag hout begroeid; we passeeren maar-éen kampoeng, Tji Empak. - Dicht-bij het eind van dit golvend terrein gekomen, zien we ons eensklaps verplaatst in een geheel ander tooneel; we rijden nu door prachtig opgaand geboomte; rakelings langs onze voeten, rechts, opent zich een diep, welig begroeid ravijn: de onmetelijke oceaan wordt op kleinen afstand zichtbaar; we doorwaden de, in vergelijking met de kleine spruitjens die we doorwaadden, breede en kristalheldere Tji Panerèkèan, die met oorverdoovend gebruis over haar rotsbedding voortschuimt, beschaduwd door een liefelijk-groenend loofdak; en eensklaps bevinden we ons op genoegsaam-vlakken grond, in een sawahstreek, in den k. Poetra-pinggan. We varen met een sasak kambang ${ }^{2}$ de breede, enkel in den droogen moeson te doorwaden, Tji Poetra-pinggan over; passeeren welhaast den k. Kamoerang; en rijden nu een enorm eind, langs een mooijen weg met grasbekleeding, door een afgeschreven koffituin van 1857, treurig om aan te zien, zonder éen enkele vrucht. We passeereu per sasak (een vaste bamboebrug) de Tji Karang bedah; varen met een sasak kambang de weêr breede Tji Kidang over, aan welks overzijde de k. Parapat ligt; komen vervolgens (altijd natuurlijk om de noord het Kendeng.gebergte zich langs den horizon ziende uit-

1 Dit zal wel "ik weet niet" beteekenen. Rigg geeft daarvoor "to njaho." (M.)

${ }^{2}$ Zie vroeger. 
strekken) in een hoe-langs hoe meer bewoonde streek, de kampoengs Karang Salam, Karang Soeka en Karang Simpang door; en bereiken tegen twee uur, warm en wel, de grens van het distrikt Tjikemboelan, tegelijk de grens van de, blijkbaar welvarende pakemitan Tjikemboelan..... Daarna onmiddelijk weêr te paard, om de 10 paal, die me na de afgelegde 12 noch wachten, voor den donker tot een eind te brengen. Het is gloeijeud-heet; de gedekte lucht heeft de atmosfeer zwaar en drukkend gemaakt, en door die bewolkte lucht steekt nu de middagzon, als woû ze haar schade inhalen, henen. We varen de breede Tji Kemboelan over, op het punt waar de, eveneens waterrijke, Tji Tondjong zich in haar uitstort; zien weêr de zee van zeer nabij, en hooren van haar klotsen meer dan ons lief is; passeeren (links van ons) de Tji Kelewoeng (die zich op een voor ons onzichtbaar punt met de twee pasgenoemde rivieren vereenigt); en rijden nu, tot Parigi toe door een smalle maar grasrijke kuststrook, waar me kudden met honderde van de prachtigste buffels frappeeren, volgens den wadana het eigendom van de uitgestrekte Kampoengs Tji Bendah en Karang Bendah (de eerste onmiddelijk aan den westkant van de Tji Kidang, beiden deels langs ons pad, deels verder op naar den voet vau het Kendeng-gebergte liggende); worden aan de grens van Parigi opgewacht door den tjamat en bereiken nu, eerst den k. Astamaja, en onmiddelijk daarna de daaraan grenzende pakemitan.... Ik wou de Europeanen, die van de zegeningen door Europeesch bestuur en partikuliere ondernemingeu over Java uitgestort, altijd den mond vol hebben, wel eens in deze, van Europeeschen invloed vrij gebleven, plaats brengen, om hun te doen zien, hoe gelukkig en welvarend en bloeijend de Javaansche Maatschappij is, als men haar aan zich zelf overlaat. Van de katja-katja 1 tot de pasanggrahan bedroeg de afstand meer dan een paal; dien afstand legden we af langs een breeden, keurig onderhouden, weg, aan weêrskanten door goede woningen en nette, ompaggerde, tuinen omzoomd..... Ik ben in ekstaze over het goddelijk plekjen; ik zou er graag, ver van alle Europeanen, wonen. De pasanggrahan is zeer net, en ligt allerliefst aan de nette aloen-aloen. - Na een halfuur slapens een lange visite van den tjamat, die me vertelt, dat in de eigenlijke pakemitan Soendaneesch, maar aan het zeestrand Javaansch wordt gesproken.

1 Rigg: An arched gateway, usually constructed of bambu. 
Hevige aardschudding, van het zuiden naar het noorden(?) terwijl we zitten te praten. Ik vergat noch te noteeren, dat men ons tusschen Manondjaja en Bandjar aan bijna-alle posten bij het afrijden "bismillah!" (z. v. a. ons "ga met God") toewenschte.

20 Mei. Tegen half acht op weg uaar Tji Bening. Even-buiten de pakemitan passeeren we per overdekte, op balken rustende, sasak de breede Tji Djaloe, en komen nu terstond op Tji Djoelangah's grondgebied. Even-verder de Tji Teroesan, links naast ons, min-of-meer glooijend, pad. Na drie paal te hebben afgelegd, bereiken we de pakemitan Tji Djoelang, weêr een blijkbaar welvarende plaats; poozen even in den pasanggrahan, terwijl de paarden gereed gemaakt worden; en gaan daarop onmiddelijk verder naar het, noch 10 paal verwijderde, Tji Bening. We passeeren, op dezelfde wijs als de Tji Djaloe, de even-buiten de grens van de pakemitan gelegen Tji Waroe (de kampoeng van dien naam, als-het-ware de voorstad van de pakemitan oostelijk, hebben we reeds achter den rug); komen door den $\mathrm{k}$. Barèngkok; varen per bandoengan ${ }^{1}$ de frissche, breede, nooit doorwaadbare Tji Djoelang over (vischrijk, maar door den tjadasbodem, die alle netwerk vernielt, weinig-exploitabel voor de visscherij), over wier kronkelende wateren zich bevallig de bamboeboschjens van den, aan den overkant gelegen, $\mathrm{k}$. Pasoeketan wiegelen. We trekken dien kampoeng door; passeeren (wederom met een overdekte sasak) de Tji Pasoeketan; en bevinden ons van-nu-af in een volslagen wildernis. De grond is infaam-slecht; tjadas en anders niet; op vele plaatsen, zegt me de tjamat, is geen drie duim humus (plantaarde). Onze weg door deze eenzame streek (waarvan geen Europeesch bestuur en geen Europeesche partikulieren ooit iets zullen weten te maken) is een aaneenschakeling van up and down's. Elk benutbaar plekjen is reeds benut door den vlijtigen inlander; getuige de menichte hoekjens (soms van weinige voeten in het vierkant), met tabak (die men hier behoorlijk weet te toppen) of met djagong beplant; getuige ook de enkele kampoengs, die men vindt overal waar gelegenheid was om (van den regen afhankelijke) sawahs aante-leggen. Eerst passeeren we, links op kleinen afstand vau ons pad, den k. Nagrog, wiens kokospalmen in dit onherbergsaam oord ons vriendelijk en uitlokkend schijnen toe-te-wuiven. Daarua komen we op een soort van heuvelrug (ik zeg: "op een soort

1 bandoengan $=$ sasak kambang, een vlot op twee schuitjes. Zie vroeger. 
van" want eigenlijk is de terreinverheffing te smal om den naam van heuvel te dragen), een prachtig punt; een drietal statige boomen, een hampelas en twee doerians, werpen hun breede schaduwen over den zonnigen weg; links en rechts openen zich aan onze voeten diepe, uitgestrekte ravijnen of dalkommen welig begroeid; overal in het rond, wáarhenen men het oog ook wendt, niets dan bosch en bergen, zich als eindeloos aan elkander schakelend, en om de noord de horizon weêr begrensd door het Kendeng-gebergte. Onwillekeurig houdt de reiziger zijn paard even in, om deze wilde natuur, die een, zij het ook neêrdrukkenden, toch trotschen indruk makt, met volle teugen in-te-zwelgen. - En nu weêr en roûte, geblakerd door de tropische zon, door de eenvormige, armelijke, eenzame kuststreek. De k. Tji Dadap met zijn sawahs, dien we langs komen, maakt den indruk van een oaze in een woestenij. Evenzoo reeds (nadat we den smallen Tji Bantar Pandjang doorwaad hebben) het gezicht van het zijpad (links) naar den k. Gadog en den daaraangrenzenden k. Masawah; omdat, al zijn de kampoengszélf niet te zien, het bestaan van zoo'n zijpad de nabijheid van mensehen bewijst. Een poos later passeeren we den k. Tji Walini met zijn net-ompaggerde tuinen, vrij uitgestrekte sawahs en onder klapperboomen en bamboestruiken verscholen woningen; trekken per sasak of bamboe-bruggetjen de smalle, bijna waterlooze Lěwi Bali over, waar (voor-het-eerst na anderhalven dag) het. geloei van de branding weêr als een verre donder in onze ooren dreunt; bestijgen de steile, moeijelijke tjadashelling, tandjakan Lěwi Bali geheeten; zien van haar top een oogenblik, op korten afstand, den oumetelijken oceaan, dien we al nader en nader komen, trekken haastig den laatsten kampoeng (Tji Totok) voorbij; en stappen weldra aan de pasanggrahan te Tji Bening af.

Die pasanggrahan ligt, op geen tien ellen afstand van de zee, aan de oostzijde der monding van de vrij-breede Tji Bening. De kampoeng-zelf ligt meer binnenslands; de pasanggrahan, klein maar van al het noodige voorzien, staat eenzaam en verlaten. Maar koelte en kracht waait u tegen van de oppervlakte der wateren, die hier met woedend geweld hun schuimende golven tegen het sinalle, maar door zijn ondergrond van tjadas en zijn bekleeding met een sierlijk-gruen, roodbloeijend zeewier stevige, strand te-pletter-stooten. De monding van de Tji Bening stort tusschen twee steile tjadasklippen, die echter (zóo-onweêrstaanbaar is in deze tropen-landen de vrnchtbaarmakende en 
levenscheppende kracht der natuur) noch met allerlei struikgewas en met stakerige pandan begroeid zijn. - Letterlijk een kolonie van menschen is hier, terwille van den geëerden gast verzameld. Het eene oogenblik kan me dat hinderen; maar het andere, als ik de gezichten zie en het schaterlachen hoor, dringt zich de overtuiging aan me op, dat dit geen drukkende diensten zijn, dat het waarlijk, bij al zijn ongerief, toch-noch, evenals voor kinderen, een soort van pretjen voor hen is. Als ik al die pondoks, groot en klein, voor menschen en beesten anzie, zou ik geneigd zijn om mijn komst als een vloek voor deze goede menschen te beschouwen; maar als ik bedenk, dat men van middag noch, eenvoudig door in de onmiddelijke nabijheid wat sè̀l ${ }^{1}$ en eenige boomtakken te kappen, binnen een paar uur een keurige stalling voor zes paarden makte, zie ik in dat men zulke zaken niet te hoog moet opnemen.....

27 Mei. Gisteren-avond wachtten me noch twee verrassingen; vooreerst een verrukkelijk gezicht op de branding in westelijke richting, rozenrood gekleurd door de weêrkaatsing der laatste tinten van het wechstervend avondrood: ten-tweede na den eten een treurig, heesch gehuil van ronggèngs uit $\mathrm{Tji}$ Dadap, waaraan de kampoengman, om met haar te mogen tandakken, zijn halve of heele cent offerde. - In den loop van den avond vernam ik meteen, dat er geen $\mathrm{k}$. Tji Bening is. en dat de palrol ${ }^{2}$, waar onze pasanggrahan staat, in orde moet gehouden worden door de bewoners van een naburig, niet meer dan vijf huizen groot, kampoengkjen, Pagadoengan geheeten.

Van-ochtend oin zeven uur weêr op ons paard; wel-te-verstaan: na de Tji Bening te zijn overgestoken per bandoengan. ${ }^{3}$ Ons pad is een eenzame strandweg, nu-en-dan, waar de rotsen den doorgang versperren, een kleine bocht binnenwaarts beschrijvend: nadat we den, vlak aan den westkant van de Tji Bening gelegen, k. Tji Rĕma gepasseerd zijn, ontmoeten we tot-aan den, vịjf paal verwijderden, patrol geen anderen kampoeng meer; de eenige afwisseling is hier het doorwaden van de monding der Tji Gatar bij den djorljongor ${ }^{4}$ van dien naam geweest. $\mathrm{Na}$ den patrol gepasseerd te zijn, komen we aan steile en

1 Een rotansoort.

2 Wachthuis (zie later.)

3 Verg. p. 374.

+ Een uitspriagende hock land, een voorgeberchte. Zie Rigg in voce jongor. 
glibberige rotshellingen (lees: tjadashellingen), en vervolgeus den k. Tji Manoek voorbij (wiens bewoners voor het ouderhoud van den patrol te zorgen hebben); we doorwaden de monding van de Tji Manoek, en naderen langsaam, altijd noch over het strand gaande (dat hier zwartkleurig zand is, in den zonneschịn schitterend als diamanten) den trotschen djodjongor Batoe noenggoel die terecht zijn naam draagt, want ver in zee vooruit, door de witte branding bespat, liggen reusachtige rotsbrokken. Nadat we dit voorgeberchte zijn omgetrokken, ontmoet ons eindelịk de wadana van Mandala. We passeeren den djodjongor Kawoelan; trekken de monding van de Tji Padaboemi door; bestijgen een steile helling, vanwaar we een onmetelijk vergezicht hebben, links op den oceaan, rechts op een onmetelijke reeks van wouden en bergen, waarboven de geïzoleerde G. Tji Goeraj, zich onderscheidende door zijn half-bolronden vorm, zich in de verte verheft; en slaan nu, van die helling afdalend, landwaarts in, den k. Pamĕngpěk voorbij, den cirka $2 \frac{1}{2}$ paal langen weg naar den k. Kalapa Genep, een groote, welvarende plaats, tot 1850 de pakemitan van het distrikt (die echter alstoen naar $\mathrm{Tji}$ Kalong verplaatst werd, omdat dáar koffituinen, die weldra zouden uitsterven, te bestieren waren!) De pasanggrahan staat aan de nette aloen-aloen; we zijn hier weêr in een zuiver-Soendaneesche streek.

$\mathrm{Na}$ hier gerijsttafeld te hebben, varen we de breede Tji Medang. over (waar Kalapa Genep aan ligt), passeeren daarop den kleinen maar vriendelijken lemboer Tjantigi met zijn sawahs, en krijgen nu alras het dof geklots van de brauding weêr te hooren, gelijk we spoedig, van een heuvelrug, de zee weêr te zien krijgen, en ons daarnaar weêr langsamerhand toe buigen. Van nu af (en we zijn zeker noch naauwelijks een paal van Kalapa Genep, dus noch $10 \frac{1}{2}$ van de pakemitan verwijderd) laat zich van onze reis niets-anders zeggen, dan dat ze, hoewel niet rechtstreeks over het strand loopende, maar over een, daarvan door pandanwong als anderzins afgescheiden, paadjen, dat half gras-, half zandpad was, door de onherbergsaamste, of liever eentoonigste, afmattendste streek liep, die zich denken laat. Het zand, waar den heelen dag de zon op gebrand had, was zóo-gloeiend, dat de koelies, om hun voeten er niet meê in aan. raking te brengen, heele einden omiiepen. Van dit heele eind laat zich niets anders opteekenen, dan-dat we den $\mathrm{k}$. Tji Totak met zijn sawahs (Eden in deze wildernis) passeerden, de Tji Rodjèh (rlak aan haar monding) overvoeren, en na den 
k. Bongas gepasseerd te zijn, een tijdlang den Tji Djoelang ngadeg, met menschen uit dien kampoeng op stellaadjes er in zittende om te njirib (met kruisnetten te visschen), naast ons pad zagen voortloopen, dien we twee maal (zóo kronkelt hij hier) achter elkâar moesten doorwaden, om landwaarts-in te kunnen gaan naar het noch 2 paal verwijderde Tjikalong. Op dat binnenpad trekken we tusschen een, in 1850 aangelegden koffituin heen, die in orde moet gehouden worden door de bewoners van het naburige, frisch en koel aan de breede, kronkelende Tji Oelan gelegene, Lěwi gedè, dat we welhaast voorbijtrekken. Kort-daarop naderen we, na een diepe dalkom (door die rivier gevormd?) gepasseerd te zijn, de aan den uitersten zoom daarvan op ongeveer 150 pas van de rivier liggende pakemitan.

24. Mei. Om half-vijf wakker van den slagregen, die echter weldra ophoudt. Om half-zes gekleed en gereed, maar (ten-einde de koelies, die het goed dragen, gelegenheid te geven om een eindweegs vooruit-te-komen) eerst om half zeven op het pad. We slaan den weg naar het zeestrand weêr in, dien we Zondag gekomen zijn, maar slaan spoedig westwaarts af, en varen de breede Tji Oelan over, die ons op Paroengsch grondgebied brengt, en aan wiens oever de wadana van Mandala ons vaarwel-zegt. We trekken (altijd noch langs een landweg) de smalle Tji Dadap over, den daaraan liggenden $\mathrm{k}$. Tjidadap voorbij, den er aan grenzenden k. Tjibĕrěm door (ongeveer een paal van Tjikalong). Anderhalf paal verder komen we den $\mathrm{k}$. Tjilangla door, aan den mond van de breede Tji Langla die we overvaren, en vau wier oever we, op vijf minuten afstands, over een kale, naakte zandvlakte heen, het witte schuim der branding (noch-niet de zee-zelf, daarvoor staan we op een te-laag punt) weêr kunnen ontwaren. Na die overvaart van de Tji Langla blijven we noch een groot kwartier op een soort van binnenpad voortrijden, door de Tji langla (die zich links langs ons pad heenkronkelt, en op dezen korten afstand noch-drie rivieren, ongeveer zoo-breed als de Vecht in Maarssen, in zich opneemt, waarvan we er twee, de Tji Kawoeng ading en de Tji Tjankoewang, doorwaden; de laatste, de Tji Kawoeng ading gedè, om haar diepte, overvaren) van het eigenlijke strand, en de Tji Langla door die smalle, kale streep oeverzand van de zee, gescheiden. Eens de Tji Kawoeng ading gedè over, bevinden we ons dadelijk op het strand, dat we dan ook 9 paal ver, totdat we aan de pasanggrahan Tji 
patoedja afstappen, niet-meer verlaten. Alle denkbeeld van een eigenlijk-gezegden weg gaat hier verloren; even-goed zou men het Scheveningsche strand "een weg" kunnen noemen. De strandformatie bestaat gedurende het eerste gedeelte uit zwart, gedurende het tweede uit wit kalk- en schelpzand (kirisik, noemen het de Soendanezen), beide zeer rul, en daardoor voor de paarden moeijelijk te begaan; gedurende het derde en laatste gedeelte daarentegen uit geel, vast en hard, zand, zoo glad als een kolfbaan. Het strand was daar ook zeer breed, en de branding, betrekkelijk altijd, niet zeer fel; gelijk trouwens heele einden het geval was, waar men over den tjadasbodein die het kristalheldere water overspoelde blijkbaar ver-in-zee kon loopen. Geheelanders was het tooneel in den beginne van onzen tocht langs het strand. Daar was het maar-weinige voeten breed, en woest huilde aan onze voeten de branding, als dol van woede dat ze ons niet in haar fellen teruchslag kon meêvoeren naar de peillooze diepte, die reeds zoo-tallooze menschenlevens verslonden heeft.... Dat we geen kampoengs passeerden, spreekt wel vanzelf; we zijn hier in een zóo-eenzame streek, dat de menschen, die morgen mijn goed naar Paměngpěk moeten brengen, elf paal te loopen hebben, poor fellows! eer ze hier aan de pasanggrahan, dat wil zeggen: aan het uitgangspunt van hun wandeling zijn. Twee wachthuizen of patrols, en aan de monding der smalle Tji Saät, even-vóor de Tji Patireman haar monding (beide geen paal van de pasanggrahan) de kleine kampoeng Tjisaät, ziedaar het eenige spoor van menschelijke wezens dat ik ontdekte. De pasanggrahan is gebouwd op 25 passen van het eigenlijke strand, in een soort van zandk om of vallei, waarschijnlijk om haar te beschutten voor de felle winden; maar het treurig gevolg daarvan, in verband met het feit dat de pasanggrahan niet op "neuten" maar op den vlakken grond is gebouwd, is, dat men uit de pasanggrahan volstrekt-geen gezicht op de zee heeft; en dat men eerst een heel eind tot-aan de enkels door het rulle zand moet waden, eer men de koelte, die uit zee $\mathrm{u}$ tegenwaait, kan inademen. Ik deed het van middag, en zag toen, noch-altijd in een ver verschiet, westelijk den als een smalle, met bosch begroeiden landtong in zee vooruitspringende djodjongor (kaap) Tji Kaèngan teruch, dien ik, reeds van het eerste oogenblik dat we van daag aan het strand kwamen, in het oog kreeg (gelijktijdig met den veel-kleineren, nu reedslang gepasseerden, djodjongor Pasèrèhan).... 
25 Mei. Voor zessen op weg uaar Pamĕngpěk. De zon: schuilt noch achter de bergen. Ons pad loopt weêr langs het eenzaam strand. We vinden aan de Tji Pangoekoesan een bandoengan om ons over-te-brengen, en komen, na een zijbeddingjen, dat (nu althans) geen uitwatering in zee heeft, doorwaad te hebben, aan een trotsch, iudrukwekkend zee- en strandgezicht. Wilder en onstuimiger dan ik het noch ergens hoorde, huilt en schuint hier de branding langs en op het smalle strookjen zand, waarop we ous langsaam voortbewegen. Niets wat naar duin of strandhelling zweemt, is hier te vinden. Maar de natuur, als ware ze dat gemis zich bewust, en als woû ze toch den landbewoner beveiligen tegen het geweld der woedende baren, heeft hier reusachtige steenklompen, steile tjadas- en steenheuvels opgeworpen, die het zwalpend nat stuiten in zijn vaart; onder zoo'n, half neêrhangenden, steenklomp rijden we rakelings door. Ons pad blijft altijd onmiddelijk langs den zeeoever voortloopen, met den onmetelijken oceaan aan onze linker, een onmetelijke, even onherbergsame wildernis aan onze rechterhand. Even-vóor het steile voorgebergte Tji Kaèhan zijn we genoodzaakt (daar dat voorgebergte steil in zee vooruitsteekt), landwaarts-in te slaan, ten einde zoodoende het te kunnen doortrekken. We nemen aan de monding van de breede Tji Kaèhan, 7 paal van Tji Patoedjah, afscheid van den wadana van Nagara (hier is de grensscheiding), en varen de rivier over met een bandoengan, gemaakt door de bewoners van het, even-tevoren gepasseerde, uit 4 huizen bestaande, kampoengkjen Tji Kaboejoetan (natuurlijk bij heeredienst, in het belang van de overvaart, gesticht en instandgehouden.) We gaan al verder-en-verder landwaarts in, beklimmen den zeer steilen, uit tjadasklompen bestaanden, tandjakan Tji Kaèhan (waar verscheidene inlanders van hun paard gaan), dalen en rijzen weêr, nu-eens door niets dan alang-alang, dan weêr onder schaduwrijk geboomte voorttrekkende; zien eindelijk na een vrij lang en vermoeijend rondtrekken eensklaps van den top van tandjakan Pangnjisihan de zee zich, op misschien honderd voet beneden ons, baden in de stralen van het zonlicht, - zijn genoodzaakt, bij het afdalen van dien, in steilte aan den tandjakan niet ongelijken, tjadasheuvel (of liever klip), van onze paarden te stijgen, - doorwaden de Tji Pangnjisihan; - - moeten noch een klipbrug over; en ontdekken, als we dan eindelijk weêr aau zee uitkomen, dat we hemelsbreed misschien geen 
vijf minuten gaans in dit half uur hebben afgelegd. Maar vruchteloos, zegt de tjamat, heeft men naar een ánderen dan dezen langen en moeijelijken weg gezocht, om het voorgebergte Tji Kà̀han om te trekken. Een ding hebben we overigens nu gewonnen; de natuur, hoewel even eenzaam als vroeger, krijgt plotseling een veel vriendelijker voorkomen. De branding blijft, ja zichtbaar en hoorbaar, maar op vrij-verren afstand; verkwikkeud kabbelt aan onze voeten, langs het smalle (stellig geen zes voet breede), uit goudgeel zand bestaande, strand het blaauwe, kristalheldere water over den tjadasbodem. Groen geboomte, gedeeltelijk met bloemen getooid, welft zich boven ouze hoofden en buigt zich liefdevol en sehnsuchtig naar de zilte baren over. De weg slingert zich, met bevallige afwisseling, nu-eens langs dit vreedsaam strand, dan-weêr door het prachtigste woud dat men zich denken kan, het is met éen woord, alsof ik me weêr in de nabijheid van Soemoer bevind. Reusachtige njamploengs met hun gebogen kruinen, hun glanzig.groen gebladerte, hun eigenaardig-donkere melancholiesch-stemmende schaduwen, maakten de overeenkomst noch-treffender. Het was voor-het-éerst, dat ik ze aan Soekapoera's zuiderstand aantrof.

Even-voor den pasanggrahan Tjibabaloekan, (16 paal van Tji Patoedjah) komen we weêr voor-goed op het strand uit, dat hier weêr zeer breed en hard is. Het is \pm halftwee, tegen dat we in die kleine bamboeloods (onderhouden door den éenigen nabij-zijnden kampoeng Rantja hèrang) afstappen. We eten er haastig; en gaan nu - daar we bevreesd zijn voor regen, in gestrekten galop - altijd het strand langs en altijd met de, ver in zee vooruitspringende., landpunt (djodjongor) $\mathrm{Tji}$ Laoet èrèn in het gezicht, verder naar het noch tien paal verwijderde Pamĕngpĕk. De smalle, maar (voor een "toewan" althans) te-diepe monding van de, daar-vlak-bij saamgevloeide Tji Sanggiring en $\mathrm{Tji}$ Merak varen we over; en voort gaat het weêr in snellen galop, hetgeen op het steenharde zand ver en luid en vrolijk weêrklinkt. Naar gissing $2 \frac{1}{2}$ paal van Pamĕngpěk slaan we een landweg in, die ons welhaast in de bewoonde wereld brengt. Pamĕngpěk (vroeger de hoofdplaats van het distrikt, die echter in 1853 verlegd is naar Tjikadjang; óok-alweêr om de koffikultuur) ligt namelijk in een uitgestrekte, vruchtbare vlakte, die zoover het oog reikt, met sawahs, afgewisseld door kampoengs, gevuld is. Het terrein golft hier niet noemenswaardig meer; alom heeft de vlijt van den landman op het landschap 
zijn stempel gedrukt; men waant zieh waarlijk verplaatst in dc vlakte van Bandoeng. Die vlakte van Pamĕngpěk, waar de padi in 4 à $4 \frac{1}{2}$ maand rijp is, is dan-ook de voorraadschuur voor het 37 paal verwijderde Tjikadjang, (waar ze, volgens den tjamat, 12 maanden noodig heeft om te rijpen.) Tusschen sawahs doorrijdende, passeeren we $\mathrm{k}$. Tjiawi, doorwaden de smalle Tji Kaso en Tji Paleboe (die echter waterrijk genoech zijn om voor de besproeijing der sawahs benuttigd te worden), passeeren vervolgens $k$. Paäs, en stappen welhaast aan de pasanggrahan te Pamĕngpěk (gelegen aan den, met een weelderig-groenen tjaringin prijkenden aloen-aloen) af.

26 Mei....

27 Mei.... Om zes uur door een even-vriendelijke landstreek als gisteren in gestrekten draf naar Tjiěrih. De kampoengs Tjidahan, Mantja gahar, Pamalajan en Tegal gedè liggen bevallig tusschen de sawahs verspreid, die, daar het midden in den oogsttijd is, met menschen en saoengs 1 overal schilderachtig gestoffeerd zijn..... Dicht bij k. Tjiěrih verminderen de sawahs (waarschijnlijk omdat we hier vlák aan zee komen), en vertoont zich de streek als een vlak, eenvormig grasland. De kampoeng (waar we vóor achten aankomen) is klein, en makt een treurigen indruk, omdat geen-enkele boom of struik de bamboewoningen overschaduwt. De pasanggrahan is weêr een klein, op den vlakken grond gebouwd, bamboeloodsjen, vanwaar men een frisch en ruim uitzicht op de nabij zijnde zee heeft....

28 Mei.... De reis naar Boengboelan aangenomen. Acht paal ver in westelijke richting, op korten afstand van het strand (waarop we nu-en-dan uitkomen) eeu eentoonigen, eenzamen zandweg langs, altijd met het voorgebergte Haoer Tjengkoek in het gezicht, rechts groene, met gras begroeide heuvelruggen, begroeid met dungezaaide, wijduiteenstaande tangkal gebang. ${ }^{2}$ We doorwaden Tji Paserangan, Tji Pasèrèhan, Tji Mangkè, Tji Tjadas; steken de Tji Mari met een bamboevlot over; en vervolgens op dezelfde wijs de ongeloofelijk-snelstroomende monding van de Tji Kandang, die we door macht van mannen, die tot-aan den hals door het water waden, en van een èrètan (een verbindingslijn van rotan tusschen de twee oevers, geheel volgens hetzelfde systeem werkend als het touw bij onze ponten)

1 Hutten in de hoema's; zie vroeger.

${ }^{2}$ Gěbangpaim. 
gelukkig overkomen, omdat er geen hoog water is; wanneer het ongeluk wil dat er bandjir is, zoodat de breede bedding, die nu voor twee-derden droog ligt, volloopt, kan men soms twee, drie dagen wachten "dum defluat amnis."

Even-voorbij den patrol aan géne (de westelijke) zijde van de Tji Kandang slaan we landwaarts in, ten einde ons in noord-noordwestelijke richting naar het, noch negen paal verwijderde, Boengboelan te wenden. Ik kan van dien weg nietveel-anders zeggen, dan dat hij enorm kronkelt, en een aaneenschakeling van steile up-and-downs is; dat het gedeelte dicht-bij de kust door niets dan alang-alang loopt, terwijl verder-op prachtige bosschen (waaronder reusachtig-groote en hooge bamboebosschen) den weg omzoomen; dat de formatie van het terrein zeer bergachtig is, heuvels en bergen, de een grooter de ander kleiner, zoover het oog reikt, natuurlijk met huiveringwekkenddiepe ravijnen er tusschen; dat water en kampoengs er tot de zeldzaamheden behooren (den heelen weg langs niet-anders dan k. Kadoe poegoer; eerst in de nabijheid van Boengboelan werd het in dit opricht weêr beter, en passeerden we den Tji Saroewa met den k. Tji Boelakan, daarna noch k. Lioeng goenoeng en k. Handjoewang).....

29 Mei. Elke toerist zou ik een tocht van Boengboelan naar Tjimanoek durven aanraden..... De weg is misschien (hoewel maar 16 paal lang) de moeijelijkste van heel Java; maar de trotsche gezichten, waarop het oog met verrukking staart, loonen die moeite dubbel. - Boengboelan uitgaande, heeft men den min-of-meer boogvormige G. Sang Hiang lawan in het front; rijdt door een, reeds golvende, maar zeer sawahrijke en bebouwde streek, (de Tji Baloeboer doorwadende, den k. Baroebjoer voorbij, alsmede de kampoengs Badjong en Kipoetat, de Tji Rompang vervolgens liefelijk-ruischend links van zich, daarop de Tji Hikĕ doorwadènde, even-vóor haar uitwatering in de Tji Rompang, die zich hier kronkelt, zoodat men ook-haar vervolgens moet doorwaden); doorwaadt de Tji Boeni nagara en de Tji Talaga; en bevindt zich alsdan op het zadel van den Sang Hiang lawan, de reeks van steile, moeijelijke klimmingen en dalingen beginnend, die niet weêr ophouden, voordat men een paar paal van Tjimanoek is gekomen. De overtrekking van den hoogen Sang Hiang lawan duurt lang, maar valt niet lang, omdat men voortdurend door maagdelijk woud rijdt, welks donker loof de gloed der zonnestralen afweert. De Tji Awi tali, an den noord- 
oostelijken voet van den Sang Hiang lawan, doorwaad hebbende, passeert men achtereenvolgens den k. Nangka roeka, (na den Tji Sariniĕn doorwaad te hebben) k. Poespa, doorwaadt den Tji Tondjong bĕrĕm, passeert den k. Tji Linggar en den, aan de Tji Pĕndĕj liggenden, kampoeng van dien naam, alsmede k. Daroen (deze-laatsten allen dicht-bij elkâar). - Men bevindt zich hier in het land van de arènpalmen; de bosschen zijn er vol van. Ik verneem van den wadana, dat zelfs op die, in het wild-groeijende, boomen eigendomsrecht bestaat. Door de wadana's krijgt ieder gezin zijn bepaald aantal boomen in wettigen eigendom en wee den indringer, die zich daaraan mocht willen vergrijpen; hij wordt verklaagd en gestraft. De voordeelen, die de arènsuiker afwerpt, zijn groot; tot twintig jaar kan een boom getapt worden, maar de schaduwzijde, zei de wadana, is, dat de bevolking de padikultuur verwaarlonst en zich met dit, makkelijker verkregen, voordeel vergenoegt. Het gezicht op de Tji Panangen, onstuimig voortbruischend over reusarhtige rotsblokken in zijn, tusschen steile tandjakans ingezonken rotsbedding, is zeer schoon; de afdaling er naar toe, en de beklimming van zijn waterscheiding aan de oostzijde daarentegen zeer bezwaarlijk. - Hetzelfde is toepasselijk op de Tji Ketjemban (die men bereikt na $\mathrm{k}$. Limoes gepasseerd te hebben) - Ook van den Tji-Bitoeng geldt het, hoewel in mindere mate. We komen nu in een dorre alang-alang-streek, den k. Pasir Garoe voorbij, en dalen, dalen, alsof er geen eind aan zou komen, en zoo-steil dat verscheiden personen van hun paard stijgen, den Pasir Garoe af naar den Tji L Legak njènang. En nu duurde het maar weinige oogenblikken meer, of we bereikten het treffendste, indrukwekkendste natuurtooneel dat ik noch ooit aanschouwde. Verbeeld $\mathrm{u}$, aan onze voeten de breede, schuimende en kokende, Tji Boeta roewa, stellig vịf-en twintig voet beneden de vaste houten brug die we gereed stonden over te trekken; en onmiddelijk aan haar overzijde een hooge, genoechzaam-loodrecht omhoogrijzende bergrug, bedekt met ondoordringbaar-dicht Urwald, waaronder b. v. Rasamala's van meer dan honderd voet lengte, en (tusschen het geboomte door, naauwelijks zichtbaar) in die helling, die eigenlijk geen helling heeten mag, slangvormige uitkappingen, waarlangs de reiziger zich naar boven moet werken. Ik begrijp nog niet, hoe ik den moed gehad heb om op mijn paard te blijven, want aan de eene zijde van het bergpad niets dan de loodrecht-omhoogrijzende 
bergrug, aan de andere zijde, eveneens rakelings naast dat pad, de diepe, even-steil afdalende, afgrond, niet minder gevaarlijk al is hij met vriendelijk groen en allerlei geboomte bedekt. Maar "audaces fortuna juvat"; ik bracht het van den, meer dan tien minuten vereischenden, tocht er behouden af.

Ik heb geen lust om van den verderen tocht meer te zeggen dan-dat we, aan den oostelijken voet van den tandjakan Tji Boeta roewa, den Tji Tjadas doorwaadden; vervolgens den Tji Halang; in den $\mathrm{k}$. Panèndjèng (ten huize van den mantri tjatjar ${ }^{1}$ ), haastig, wat aten (we waren daar noch $\pm 9 \frac{1}{2}$ paal van Tjimanoek, ruim een paal voorbij de Tji Boeta roewa); de, aan dien kampoeng zoomende, Tji Pakèndjèng doorwaadden; vervolgens de frissche, ouder het geboomte dat hem overwelft, met ooverdoovend geweld te-voorschijn-komende Tji Papandajan; den k. Sandaän passeerden; en na de Tji Djotang doorwaad te hebben en voortdurend noch enorm te zijn geklommen (altijd rijdende door een bij uitnemendheid boschrijke streek), op twee-en-een-half paal afstands van Tjimanoek in afgeschreven koffituinen kwamen, en vervolgens in nieuw aangelegde, die zich uitstrekken tot aan de grens van de pakemitan. - Als ik bedenk, dat de wadana me zê̂, ditmaal weêr een zeer slecht jaar te maken met de koffi, uitgezonderd een in 1857 omgekapte oude tuin, waarvan de uitloopsels, nu weêr prachtige boomen, vol vruchten zitten, verbaast het me dat men dat systeem niet veel-meer op oude tuinen toepast..... Tjimanoek, een schepping van het kultuurstelsel en enkel ten behoeve van de koffikultuur gesticht (evenals b. v. Pĕngalèngan), ligt, naar ik gis, op 5000 voet hoogte, een kwartier gaans beoosten den G. Papandajan.....

30 Mei.... De wadana vertelt me allerlei, voor mij nieuwe dingen, o. a. het volgende. Het is te Tjimanoek zóo-koud, dat noch padi noch klappers er groeijen willen. - ()nder palawidja verstaat men: 1) tèrong, 2) roepa-roepa-katjang, 3) roeparoepa hoewi, 4) djagong, 5) bako. ${ }^{2}$ De naam palawidja wordt ook-dán er aan gegeven, wanneer ze (zooals b. v. hier) niet als "tweede gewas" geplant worden, m. a. w. ook-dán, wanneer ze geplant worden op grond waar niet eerst padi op verbouwd is. - Tjoekè wordt enkel geheven van padi en van kapas (welke-laatste men hier-en-daar, hoewel op zeer kleine

1 Vaccinateur.

2 Tèrong. Rigg: the eggplant, Solanum Melongena. - bako is tabak. 
schaal, hoogstens 3 pikols éen man, verbouwt). Van arènsuiker wordt belasting geheven, als men ze ter-markt-brengt; niet wanneer men ze uit- of doorvoert naar elders (gelijk in Garoet en Tarogong, waar van elk-doorgevoerd of uitgevoerd pikoelan 5 cents wordt geheven, en tot-aan de betaling de suiker in beslag wordt genomen). Het vroegere regentschap Parakan moentjang bestond uit de distrikten Kandang wesi, Batoewangi, Sèlatjaoe, Taradjoe, Tasik Malaja, Singaparna, Indihiang, Tjiamis, Tandjoeng-sari, en Madjalaja. Voorts was er een regentschap Limbangan. Die twee regentschappen heeft de kompagnie tot éen gemaakt, en (met afscheuring van al de opgenoemde stukken, en vervallen-verklaring van het Limbangansche regentenhuis) aan de vroegere regenten van Parakan moentjang gegeven, die ze naar Garoet deed verhuizen.

31 Mei. Het is zóo-koud, en er waait een zoo-kille, schrale noordoostenwind, dat mijn handen 's ochtends letterlijk verkleumd zijn, ik de deuren moet sluiten, en het schrijven me moeite kost.....

1 Juni. Van daag is het tegen zes uur te Tjimanoek verrukkelijk weêr, niets koud; kompleet een koele, frissche, Hollandsche zomermorgen. Van den, 16 paal langeu, weg naar Bandjarwangi (ik ging niet over Tjikadjang, maar recht-toe, recht-aan, door de koffituinen) laat zich niets-anders zeggen, dan dat hị eerst door een eindeloos-lange reeks van koffituinen, oude, jonge en afgeschreven, loopt; vervolgens door prachtig bosch; en het laatste gedeelte door tegal-velden; al dalende, sterk dalende, naar het in een kleine dalkom liggende, maar door de Tji Kaèhan noch-al redelijk-koele, Bandjarwangi. Bergen en niets dan bergen, waartusschen echter nu-en-dan lachende valleijen, begrenzen aan alle kanten deze gezichteinder. Noemenswaardige kampoengs of rivieren passeerden we niet; enkel k. Tjhidĕng, den smallen 'Tji Haroes, en den k. Waroeng tjagah an de twee kleine, maar toch overbrugde spruitjens of riviertjens Tji Barèngkok en Tji Kembar. Voorts hier-en-daar paralaks (bereidingsplaatsen van de koffi in het gebergte), alsmede waroengs (waaronder waroeng Kiara rambaj, zoo geheeten naar een prachtigen kiara)..... De pasanggrahan is hier, evenals te Tjimanoek, zeer net. Het voorpleintjen smaakvol aangelegd als Engelsch werk, met een fraai rozenperk in het midden. Het gezicht, boven van den weg, op de pakemitan en de Tji Kaèngan, zich als een zilveren lint kron- 
kelend door de kleine dalkom, was allervriendelijkst. Vrolijk wapperde de Hollandsche vlag in den top van een waringin op den aloen-aloen.

2 Juni. Als een merkwaardige bizonderheid, en een treffend bewijs hoe-voorzichtig men met zoogenaamd-onschuldige regelingen in Holland wezen moet, vermeld ik noch, dat gisterenavond, hier in het hartjen van de wildernis, deze onnoozele wadana me vroeg, of het waar was, wat men vertelde, dat nu ook Maleijers, Soendaneezen, Javanen en Amboneezen "kontolioer" konden worden. - Ook van den Samarangschen spoorweg wist de man af. De Soendaneesche volksboeken kende hij, en ze werden, zeî hij, wèl gekocht - namelijk door degenen die "bisa narembang." 1 Door de somahs, d. w. z. door de niethoofden of mènaks echter noch weinich of niet, omdat daaronder zeer weinigen zijn, die lezen kunnen. De wadana betreurde het overigens zeer, dat die volksboeken allen "meer Javaansch dan Soendaneesch bevatten." Alleen de Woelang poetra, zeî hij, is echt Soendaneesch, maar - kasar basana. De wadana van Tjimanoek, een zeer schrander man, kwam er rond voor uit dat in zijn distrikt (Kandang Wesi) hij de éenige was, die de boekjens kocht.

En nu een woord over mijn tocht vau Bandjar-wangi naar hier (Dĕděl, hoofdplaats van het distrikt Taradjoe). Een wóord; want als ik zeg dat de weg van Bandjarwangi naar Děděl loopt door eenzame, uit allerslechtsten grond, vol roode tjadas, bestaande galagahstreek, en een aaneenschakeling van vermoei. jende up-and-down's is, totdat men eindelijk met een vrijgeleidelijke, maar zeer sterke, en meer dan een paal lange daling in de ongeloofelijk-enge dalkom (ze is stellig in omtrek niet meer dan vijf minuten groot) neêrdaalt, waarin het kleine Děděl ligt; dan heb ik er alles van gezegd, wat er van te zeggen valt. Het landschap heeft een doodsch, eenvormig, voorkomen. Schaars rust het oog op kampoengs en sawahs, hoewel er aan water geen gebrek schijnt te zijn, te oordeelen; deels naar het betrekkelijk-groot aantal rivieren en riviertjens, dat we op den 14 paal langen tocht kruisten (de Tji Hoeni, 2 paal, de Tji Lèmo, 4 paal van Bandjarwangi, doorwaadden we; verderop passeerden we, per bamboebrug, achtereenvolgens de Tji Djaloepang, de Tji Pongpok, de Tji Djaloe - even-voorbij het

1 De tembangs kunnen lezen. (M.) 
binnenlandsche koffipakhuis $\mathrm{T} j \mathrm{ji}$ djaloe - den $\mathrm{T} j \mathrm{ji}$ Palasari, en den Tji Teroes), deels naar de enorme watermassa, die een paar solokans langs onzen weg bleken te bevatten. Ik schrijf dat toe aan drie oorzaken: den infamen grond, de menschenschaarschte in-het-algemeen in het Soekapoerasche, en de nabijheid van bosschen met arènboomen (in wier nabijheid de bevolking zich bij-voorkeur vestigt, omdat ze dan met weinich moeite $f 1$ tot $f 2$ daags kan verdienen). We passeerden of doortrokken geenandere kampoengs dan Tjihoeni (aan de Tji Loemboeng), Tjirandjang (aan de Tji Lèmo), Nanggerang (door een koffituin, die, hoewel pas 6 of 7 jaren oud, op sterven stond, voor ons oog verborgen), Nagasari en Indoerarang. - Om twaalf uur aankomst te Děděl..... Ik verneem tot mijn groote teleurstelling, dat de pantoens, van wie men me zóoveel had voorgespiegeld, hier niet-meer zijn; alléen éen noch, dien ik weêr moet wechsturen, omdat hij niets kent dan een stuk van de Pangoeng-karatou. Dit is me een dubbele teleurstelling, omdat te Bandjarwangi de pantoen óok-al niet bruikbaar was, en omdat van konferenties met hoofden (de ondervinding in Bantam heeft het me geleerd) weinich of geen heil te wachten is. Men moet afluistereu; gaat men aan het navrage u of een of ander woord ook hier gebruikt wordt, dan is het "ja-en-amen" het onveranderlijk antwoord.....

5 Juni. Om zes uur weêr op mijn paard naar het, 17 paal verre, Tji Balong. De weg weêr tout comme à l'ordinaire, een aaneenschakeling van up-and-down's. De landstreek weêr kaal en boomloos; roodkleurige grond, sterk bezwangerd met tjadas en vol reusachtige steenbrokken (op éen punt hing zoo'n liefelijk steenbrok over ons, niet-meer dan vier voet breed, eu aan den anderen kant door een formeelen rotswand begrensd, pad); kreupelhout, harèndong en alang-alang de eenige terreinbekleeding. Het uitzicht weêr even doodsch en eenvormig, op een eindelooze reeks van onbewoonde en onbebouwde heuvelen bergruggen, die zich van daag, bij de dikbewolkte lucht, noch-valer dau anders voordoen. Kampoengs en menschen weêr dun-gezaaid. Heilig, heilig vargeleken bij zoo'n bergland, ons vlakke Holland!

We doorwaden den Tji Windoe (d. w. z. per sasak overgaan); passeeren den Tji Awi en den daaraanliggenden k. Giri pati; komen door den k. Djati aan den Tji Teroes, die we daarop 
doorwaden; passeeren k. Pari : doorwaden den Tji Baganding, passeeren den 'Tji baros, en daarop den kampoeng van dien naam; daarop den Tji Pendè en den kampoeng van dien naam (de grens van het distrikt Taradjoe); vier of vijf maal den kronkelenden Tji Gorowong; den Tji Dadap en den kampoeng van dien naam; daarna den Tji Païngěn en den Tji Tjandoekoer, met den daartusschen liggenden k. Tjirĕnděh, den Tji Běrěm; den Tji Panas; doorwaden de Tji Kandawĕ, passeeren de Tji Goenoeng, den kampoeng van dien naam, en de, vlák aan den weg liggende, blijkens de saoengs of badkamertjens gebruikt wordende, warmwater-bron (vijf paal van Salatjaoe), deñ k. Sangkoer, den Tji Honjè, na den kampoeng van dien naam gepasseerd te zijn; komen daarop, 5 of 10 minuten vóor Salatjaoe, het pad voorbij dat ons straks naar Tjibalang moet leiden; den k. Parong pontèng doorgegaan zijnde, bevinden we ons nu in, de pakemitan Salatjaoe, met zijn uitgestrekte sawahvlakte.... Ik vervolg daarop de reis naar het noch een kleine 4 paal verwijderde. Tji Balong. Dit gedeelte van den weg is veel vriendelijker; bet loopt door een bebouwde en bewoonde landstreek. We passeeren den Tji Liwat, den k. Tjidas ngampar (de vroegere pakemitan) eu doorwaden den Tji Panengah, passeeren, een eind verder-op, den k. Tjoekang antjad, den Tji Šěr, den Tji Moentjang, en den k. Sawah hilir; doorwaden den Tji Limbangan (grens van Salatjaoe); den Tji Lilitan; krïggen den Tji Longgan (waaraan ook Tji Balong ligt) in-het-oog; en stappen tegen éen uur aan de pasanggrahan af. Met-uitzondering van de 'Tji Teroes en de Tji Longgan zijn al de hierboven opgenoemde riviertjens niet meer dan kreeken.

\section{AANTEEKENINGEN OP EEN REIS DOOR TJIREBON.}

27 Juli. Tocht, van Paloembon, over Mandirantjang, naar Tjilimoes, hoofdplaats van het volkomen-Soendaneesche distrikt Beber. Een Europeaan heeft hier een katjangolie-fabriek, maar werkt sints vijf jaar niet; hij kan niet tegen zijn Chinesche konkurrenten op. Er zijn in het distrikt twee partikuliere suikerfabriekjens van Europeanen op tegalgronden; maar jaar op jaar 
werken ze-met verlies, in weêrwil (omdat het distrikt voor zijn talrijke bevolking geen sawahgrond genoech heeft) tegen twintig cents daags vrije arbeiders in overvloed te krijgen zijn. De allerhóogste produktie is 30 pikoels per bouw. Een school is in het distrikt niet, op de hoofdplaats zelfs geen pasantrèn. Uiterst-schaars degenen die lezen en schrijven kunnen. Geen toekang pantoen hier; niemand die nembangt of stukken van dien aard bezit. De Hoofden korrespondeeren in Tjirebonsch Javaansch. Op de aloen-aloen staat de prachtigste waringin, die ik totheden zag.

Tjatjah hier onbekend; somal alleen in de dienstboeken; in het gewone leven is het kollektiefwoord voor ons partik ulieren, degenen die niet-ambtenaar zijn, sikep (wel-te-verstaan, zêi men later, voorzoover ze grondbezitters, en daardoor heeredienstplichtig.zijn.) Onze oerang-manoempang (noe datang anjar, doewa tiloe taoen, tatjan boga pagavèan Goepernemèn anoe. misti ${ }^{1}$ ) heeten hier: woewoengan.

In het distrikt Beber zijn volgens den wadana 46 dessa's, en daarvan zijn maar-15 ingedeeld bij de koffikultuur; de overigen verrichten geen kultuur diensten-hoegenaamd meer. In het oostelijk gedeelte van het distrikt worden meer dan elfhonderd bouws met katjang soe-oek ${ }^{2}$ beplant; de grond is daar tanah-merah, waarop niet-anders groeijen wil.

29 Juli. In de vroegte met den wadana een uitstapjen naar den, twee paal in z.-westelijke richting verwijderden, balong ${ }^{3}$ Linggar-djati, ook-wel balong Soeltan genaamd: een ijselijkgewonen vischvijver, met een pasanggrahan er boven gebouwd, waar men overnachten kan. Hoewel sints-lang door de Sultans niet meer bezeten, wordt de vijver met bijbehoorend erf door de bevolking noch-altijd als hun eigendom beschouwd. Niemand zou het wagen een visch uit den vijver wech-te-nemen: "matak doraka të kira-kira;" " meermalen gebeurt het, dat kantjra's, 5 die, 's nachts uit den vijver in een, daarmeê in kommunikatie staanden, salokan gegaan, 's morgens door het vallen van het

1 Ik geloof, dat dit moet beteekenen: de sedert twee of drie jaar nieuw aangekomenen moeten nog niet hebben eenig werk voor het goevernement. (M.)

${ }^{2}$ Zie vroeger.

3 Vischvijver. (?)

4 Een bezondiging te weeg brengen, daar men geen gedachte op heeft.

5 Jav, en Ml. tambra, cyprinus sp. 
water niet-meer teruch konden zwemmen, door de bevolking teruchgebracht worden. - Er is een Hindoesch beeldjen (een "artjan, = gambar sama batoe, zei de wadana), waaraan noch geofferd wordt. Het is armslengte groot, niet ten-voeten-uit, de armen tegen het lijf gesloten en niet uitgebeiteld; het hoofd goed afgewerkt, zeer menschelijk van voorkomen, en redelijk gekonzerveerd. Alles wordt even-keurig onderhouden; drie menschen zijn voor dat werk afgezonderd. Het terrein behoort reeds tot Mandirantjang.

Inlandsch bestuur in Tjirebon.

1. De wadlana.

2. In plaats van onze tjamal's en patingis hier de aris (in Beber b. v. drie.)

3. De koewoe, $=$ onze roerah .

4. In de dèsa, buiten en behalve de koewoe, noch de sasaka lima, bestaande uit:

a. den ngalibi (ongeveer onze poendoeh.)

b. den lambang.

c. den ngoetjapgawè. allen staande onder de bevelen

d. den raksa-boemi.

e. den panglima. van den ngahibi.

In de Preanger.

1. De wadana.

2. De tjamat's, plaatsvervangers van den wadana.

3. De patinggi's, plaatsvervangers van de tjamats.

4. De roerali's.

5. De poendoeh, helper en wakil van den roerah.

Babaoe (= onze djaga satroe) staande onder den wadana, en de middenpersoon, door wiens tusschenkomst, ingeval er sèmah 1 in het distrikt komen, reizende ambtenaren of de resident b. v., paarden, eten, tetebah ${ }^{2}$ enz. van de dorpshoofden wordt gerekwireerd. De poerah mĕntah. ${ }^{3}$

Poernabaja (= onze kabajan), de handlangers van de babaoe's (djaga-satroe's), die de kampongs rondgaan om meê-te-deelen

1 Bezoekers, vreemden.

1 Muziekinstrumenten. (?)

3 Wiens werk het is te vragen (?) 
aan de dorpshoofden, wat er wordt gerekwireerd; en die daarom in het bezit moeten zijn van een paard.

Kabajan. Iedere dessa heeft er hier een of meer. Het zijn degenen, die op last van den koewoe in de dessa het door den poernabaja, uit naam van den babaoe, gerekwireerde gaan opschommelen. In de Preanger zijn deze kabajan's onbekend.

De koewoe's en de sasaka-lima worden gekozen door de dessabewoners.

Van een mantri besar, gelijk die in de Preanger is, woonachtig op de hoofdplaats, staande onder den Patih, en diens wakil, weet men in Tjirebon niet.

Hier kapala djalan (staande onder den wadana), - bij ons koemetir djalan (eveneens staande onder den wadana; maar dau bovendien in de Preanger per regentschap noch éen koemetir besar, staande onder den Regent, en diens bevelen omtrent de wegen overbrengend aan den wadana.)

30 Juli. Naar Lěwimoending ( \pm 18 paal van Tji Lemoes) een zuiver-soendaneesch distrikt, maar welks hoofden in hun korrespondentie weêr niets dan Javaansch gebruiken. In 1859 moet het Goevernement, zei me Masroen, al vruchteloos een verzameling van dienstbrieven hebben verlangd. - Een zeer mooije pakemitan, met een groot steenen huis voor den wadana waar ik logeerde, tegenover de kontroleurs-woning. Er schijnt niet veel alang te groeijen, althans ik zag verscheiden woningen met bamboe (sirap awi) bedekt.

31 Juli. Binnendoor (door een zijpad in-te-slaan aan de grens van Lĕwimoending, te Tjiwaringin) naar Ardjawinangoen ( $\pm 7 \frac{1}{2}$ paal) waar de twee suikerfabrieken van Ament zijn (een met een aanplant van 400 , een met 600 bouws). Een zuiver Javaansch distrikt. De wadana van Beber verzekerde me, dat in deze residentie de bevolking per bouw suikerriet $\mathrm{f} 105$ à f 120 krijgt, gemeenlijk onder drie personen verdeeld: naar de welvaart, die overal blijkbaar is, te oordeelen, komt me deze mededeeling geloofwaardig voor.

De bevolking van Ardjawinangoen, zêi men me in den pasanggrahan, "djahat sakali."

5. Aug. Aankomst te Bantar kawoeng (hoofdplaats van het Soendaneesche distrikt Salem), ruim drie paal bezuiden de rivier Pamali, grensscheiding van de Javaansch-en Soendaneesch sprekende bevolking. - In de zeestreek van Cheribon, waar de groote weg doorloopt, sprak men uitsluitend Javaansch. 
Vrije arbeiders hier niet te krijgen, voor geld noch goedc woorden, zêi me de opzichter van de militaire opname, die hier meer dan een jaar woont. Evenmin levensmiddelen, zêi hij, tenzij in ruil voor tjabè b. v. (zelfs-die plant de bevolking hier niet; en de wadana trekt zich geen van deze dingen aan, evenmin als b. v. uitbreiding van klapper-aanplant, vruchtboomen, arènpalmen, van welke-laatste ik hier geen enkel exemplaar vond).

Het distrikt bijna-alleen uit bergen bestaande, schaars-bevolkt en arm. Tóch de bevolking gehecht aan het plekjen waar ze gewonnen en geboren is. Men vertelde me, dat b. v. te Sindangwangi de bevolking (daar de grond enkel nit warlas bestaat) in dezen tijd zich letterlijk met boschblâren voedt: en op een andere plaats, na een aardstorting die verscheiden menschen deed omkomen, de rezident last gaf aan de menschen, om te verhuizen; - op geen van beide de plaatsen woû of wil men het.

Onze roerah hier koewoe; onze patinggi hier roerah; daarboven hier de warlana. Ik ben zoo gelukkig, een toekang pantoen aan-te-treffen, natuurlijk weêr blind, Bangsa goena, uit de dessa Pangrasan, die zes tjarita's (verhalen) kent. Hij was echter zóo-bevreesd voor kwade gevolgen van het mêedeelen dier verhalen, dat hij den eersten avond telkens in verzuchtingen ("astaga faïllah!" God vergeve mij") uitbarstte, en eindelijk zei, dat hij eerst wierook moest branden (makè menjan) om die gevreesde gevolgen af-te-wenden.

Een nieuw proefjen van de mogelijkheid van vrijen arbeid. Heden ( 7 Augustus) moest de wadana naar Salam, omdat de opzichter der militaire opname aldaar gisteren zijn nood kwam klagen, dat hij geen-enkel man kon krijgen om, tegen betaling, hem bij zijn opmetingen als koeli te helpen. Voor een geit durfde men $f 10$ zilver vragen. Voor een pikoelan gras (en noch wel een zeer kleinen) moet de opzichter hier 20 duiten betalen; twee paarden kosten hem aan gras (door twée menschen gesneden) $f 20$ zilver per maand.

Vroeger was in de nabijheid van Salam indigo-kultuur; maar de bevolking verliep bij-den-dag, uit haat aan het werken in de fabriek (niet zoozeer uit afkeer van de kultuur). Eerst-na de intrekking der kultuur is ze teruchgekomen. De beschaving gaat hier vooruit. Ik zag briefjens van den wadana in het Maleisch geschreven, aan den opmeter hier, maar eindigend met ons "Goedemorgen!" 
Hier de oude duiten noch in omloop.

In deze maand Moeloed mag men hier 1. niet trouwen, 2. geen huizen bouwen (doet men het, kahoeroewan '), 3. de gamelan niet slaan (in de Preanger enkel--2; 1 enkel van den 1sten tot den 12den; 3 niet bekend). Nooit mogen in dit distrikt wajang worden vertoond (waarschijnlijk uit gehechtheid aan de adat der Soendaneezen). Lain hadis (voorschrift van den profeet), maar tjěk kitab paririmbon, zei M., 1 en 2 , en daarom bidah. ${ }^{2}$

Men gebruikt hier het Javaansche letterschrift, maar zoote-zeggen niemand in dit distrikt, die lezen of schrijven kan. Vroeger de mantri-koedang belast met den verkoop der Soendaneesche volksboeken; maar nu sints geruimen tijd-die onverkoopbare voorraad weêr teruchgezonden.

Hier op de hoofdplaats een pasantrèn, maar volgens den wadana door zeer weinigen maar bezocht.

Boven een Maleische vertaling van een Javaansche dienstbrief aan den wadana van Losari, zette de wadana hier doodbedaard: Vertaalan. Ik verneem nu, dat niet te Bantar kawoeng maar te Pangrasan de bovenbesproken pasantrèn staat, doch dat er op dit oogenblik geen-enkel kind meer is.

Hier geen-enkele Soendanees, die schrijven kan, wel de wadana, de assistent, de djoeroe-toelissen (éen partikulier), de pangoeloe en al de kaoem-menschen, de mantri koedang, maar - allen Javanen. Van de 20 koewoe's onder den loerah van Bantar-kawoeng, maar-twee', die een beetjen (Javaansch schrift, geen Arabiesch of Hollandsch) kunnen schrijven; al de rapporten van koewoe's en loerahs geschieden hier dan-ook mondeling (koe soengoet) aan den djoeroetoelis (de koewoe's samen met hun loerah).

13 Augustus. Komst te Tji Ledoeg, hoofdstad van Losari (Tjirebon), een buitengemeen-welvarende streek, en zeer nette distrikthoofdplaats. Het $\mathrm{zw}$ arte suikerriet, vroeger op bevel van den Tjirebonschen regent overal uitgeroeid, door hem, op aansporing van den tegenwoordigen inspekteur (toen kontroleur) weêr aangeplant, en van-hier-uit allengs over geheel Java verspreid. Er zijn hier twee Goevernements-suikerfabrieken,

1 Dan krijgt men brand. (M.)

${ }^{2}$ Parirembon, zal wel het Jav. primbon zijn, toover formule, een geheimzinnig teeken; maar de zin is mij toch niet duidelijk. (M) 
beiden van Gonzalvez, en vier partikuliere. Die partikuliere fabrieken huren de sawahs van de bevolking à $f 17$ per bouw + betaling van de padjag ( $\pm f 7)$; zij laten ze bewerken door boedjangs. De Goevernements-fabrieken hier hebben voor het transport van het riet naar de fabrieken vrije kontrakten met de bevolking; het aantal personen die hun buffels aanbieden, overtreft tegenwoordig de behoefte. De wadana vergeleek overigens, zeer terecht, den kleinen man bij kinderen, die men moet dwingen tot hetgeen tot hun eigen bestwil dient. Hij zeî, dat bij zijn komst de streek een wildernis was; dat hij had moeten $\mathrm{d}$ wingen om palawidja, 1 klappers als anderzins te planten; maar dat, nu de kleine man het voordeel daarvan bijj-ondervinding, kende, dwang langsamerhand onnoodig wordt. Een treffend bewijs, hoe onverschillig de kleine man is, deelde hij me meê; in het heele distrikt was tot vóor korten tijd noch-geen-enkele doekoe of doerian; hij gaf nu van den aanplant een voorbeeld.

De vadana heette hier, tot vóor een groote twintig jaar, demang divizie; de tegenwoordige koewoe aris (ze heeten niet aris-alléen) toen wadana. De naam koewoe, zeî hij, afkomstig dáarvan dat er vóor de komst van Sheikh Moelana een koewoe Tjirebon was, die jaarlijks tarasi als bebakti (wij zouden zeggen als cijns, als bewijs van cijnsbaarneid) naar Padjadjaran zond; de Sultans-regeering bestond toen noch-niet. De overeenkomst van het Noordbantamsch en het Tjirebonsch bleek me ook uit zijn mededeelingen haar grond te hebben in de vroegere onderhoorigheid van Noordbantam aan Tjirebon, en het gedurig uitzenden van Tjirebonners daarhenen. Demang is hier nu, even als in de Preanger, een bloote titel; demang wadana.

I.OSSE OPMERKINGEN OP EEN UITSTAPJEN DOOR DE ZUIDELIJKE EN WESTELIJKE DISTRIKTEN VAN TJIANDJOER.

Van Tji Hělět (vroeger patrol op de grens van Pạngalèngan en Tjidamar) opgebroken (op de kaart Tji Bĕlět). Vau Tji Hělět kwamen we te Pamojanan (niets dan een paar huizen). Van Pamojanan te Njalindoeng (op de kaart Ngalindoeng,

\footnotetext{
1 Tweede gewassen.
} 
waar buiten van der Wijck noch-nooit iemand geweest is). [Hierbij staat als datum 23 Junij 1865, moet zijn 1866(M)]. Van Njalindoeng over Tiwoe gentèng (op de kaart Tjiwoe genting en ten zuiden van Pamalajan geplaatst) en Tjikarang naar Pamalajan.

Van Pamalajan over Tjibatoer en Tjiseroewa naar Tjidaoen (aan den O. oever van de Tji Damar). De (zooals men beweert, gemeten), afstanden bedragen, volgens opgave, van Pangalèngan tot Pamojanan $11 \frac{1}{2}$ paal, van Pamojanan tot Njalindoeng 6 paal, van Njalindoeng tot Tiwoe-gentèng 7 paal, van Tiwoegenteng tot Pamalajan 7 paal, van Pamalajan tot Tjidaoen 9 paal. We passeerden, buiten een menigte kleinere spruitjens, tusschen Njalindoeng en Pamalajan, de Tji Gembong (nadat we het reusachtig-lange en steile, uit taněh lěĕr en losse steenen bestaande, toengtoeroenan Gembong waren afgedaald), de Tji Pitjoeng, de Tjitengah, de Tji Talaga en de Tji Awi (van de, op de kaart als een vrij-groote rivier afgeteekende, Tji Kawang djamboeng heb ik niets gemerkt); van Pamalajan vertrekkende, staken we den suelstroomenden Tji Laki (lees met de $a$ in ons vader; zoo spreekt men het uit) over, en passeerden vervolgens, voor we aan Tjidaoen kwamen, een onnoemelijke menigte kleine spruitjens en beekjens, wier namen ik vergeten ben.

Hierna volgen deze opmerkingen: "Vet of mager van g r o n d " heet in het Javaansch, het eerste loh, het tweede garres.

Volgens v. d. Tuuk (Tijdschrift voor Ned. Indië, 1851 I bl. 341) is "Loetoeng kasaroeng" een bijnaam van Tjioeng Wanara. Hij noemt de geschiedenis van Loetoeng kasaroeng een "Sundanesche wajang" (?!) Tongèrè banèn is een tongèrètsoort, die men enkel in zware bosschen vindt, en die, den h e elen dag door (ik hoorde ze, bij prachtigen zonneschijn, tusschen tienen en twaalven) een vervaarlijk snerpend geluid maken.

V. d. Tuuk 'berispt v. Hoëvell, dat hij kedeboes schrijft, en zegt dat het moet wezên: godoboes. Allebeî mis: In Buitenzorg en Batavia zegt men: gedeboes, en in de Preanger: deboes. Het pègoe, waar Rigg pègon van wil afleiden, en dat hij vertaalt door een vreemde uitspraak hebbend, bestaat niet, en moet zijn: pègo, beteekenende: niet een vreem de, maar een onduidelijke en daardoor onverstaanbare uitspraak hebben (zooals b. v. de Chinezen als ze Maleisch spreken.)"

Verder vinden we van den weg nog slechts deze korte aanteekening "Van Tjidaoen vertrekkende, trokken we op een 
paar paal afstands vandaar de Tji Damar, de Tji Toè en de Tji Widi over, en de Tji Pandak, aan welks westzijde (een waar tijgerland; van 1 Januarij-31 Maart waren daar 12 menschen opgepeuzeld) een tempat tjatjar en de k. Tji Pandak. Ongeveer halfweg Sindang barang trokken we de Tji Boentoe en de Tji Oedjoeng over, rustten in de k. Tji Oedjoeng; passeerden k. Tji Olèng en verschillende andere kampoengkjens, allen levende van den zoutaanmaak; en kwamen eindelijk de monding van de Tji Sadéa langs een tweede Tji Toè over te Sindang barang.

Tji Damar is het tijgerland bij-uitnemendheid; in Mei van dit jaar 13 menschen opgepeuzeld. - En van-dáar het zonderlinge feit, dat men in héel Tji Damar geen-enkele waroeng vindt: "tjadoe" zeî men, "koe-sabab loba maoeng"; ${ }^{1}$ ging men waroeng-houden, de tijgers zouden "aboes ka lemboer." 2

1 Thadoe is mij niet helder, het andere beteekent: om reden van de vele tijgers. (M).

1 Loopen naar het dorp. (M.) 